Guilherme Martins Crocetti

\title{
Halobacterium salinarum NRC-1: Rede de Regulação Gênica e sua análise probabilística
}

Ribeirão Preto, Brasil

Fevereiro, 2018 

Guilherme Martins Crocetti

\title{
Halobacterium salinarum NRC-1: Rede de Regulação Gênica e sua análise probabilística
}

\author{
Dissertação apresentada ao Instituto de Ma- \\ temática e Estatística da Universidade de São \\ Paulo para obtenção do Título de Mestre em \\ Ciências em Bioinformática \\ Universidade de São Paulo — USP \\ Programa de Pós-Graduação em Bioinformática
}

Orientador: Ricardo Zorzetto Nicoliello Vêncio

Ribeirão Preto, Brasil

Fevereiro, 2018 
Obrigado ao meu orientador, Prof. Dr. Ricardo Z. N. Vêncio, não só pela orientação, mas principalmente pela diversão fornecida durante toda a dissertação, e em especial nos momentos mais críticos, constituídos em sua maioria de barreiras burocráticas desnecessárias, e que só atrapalham o desenvolvimento da ciência brasileira, e em particular à Bioinformática. Agradeço também a agência CAPES - Coordenadoria de Aperfeiçoamento de Pessoal de Nível Superior pelo financiamento ao longo deste trabalho.

Em relação à aquisição dos dados empregados na dissertação, a participação do LaBiSisMi (Laboratório de Biologia Sistêmica de Microrganismos) foi essencial, representado na maioria das vezes pela Profa. Dra. Tie Koide, que contribuiu direta ou indiretamente na maioria dos dados utilizados por este trabalho, e em alguns momentos com sugestões à própria dissertação. A novidade incorporada na estrutura proposta só foi possível graças aos experimentos realizados pelos membros deste laboratório, e portanto, obrigado.

Obrigado a todos os colegas e amigos que contribuíram para este trabalho, na maioria das vezes através de simples discussões, em sua maioria relacionadas à Bioinformática e ciência em geral, essenciais à manutenção da saúde mental, fundamental para a conclusão de qualquer trabalho. Em especial aos amigos do LabPIB - Laboratório de Processamento de Informação Biológica, companheiros de orientador, e aos amigos do LSSB - Laboratório de Sistemas e Serviços Biomédicos, que apesar de trabalharem em temas distintos compartilham o mesmo amor pela ciência.

Por último, e mais importante, um agradecimento à minha família, a maior responsável por permitir a conclusão deste trabalho, tanto pelo financiamento quanto pelo apoio encontrado, não exclusivo desta etapa, mas também durante a formação educacional e pessoal fornecida nos primeiros anos, sem isso seria impossível chegar até aqui. 


\section{Resumo}

Este trabalho teve como objetivo principal modelar a Rede de Regulação Gênica do organismo modelo Halobacterium salinarum NRC-1, estabelecendo interações entre as entidades da rede por intermédio de experimentos inéditos de interação física: ChIP*, RIP-* e dRNA-seq. Em contraponto com as abordagens clássicas de construção de redes, que estimam interações através de medições de expressão gênica, este trabalho as estabeleceu exclusivamente de interações físicas, permitindo que a estrutura final seja uma representação mais fiel ao fenômeno físico de regulação gênica, baseando-se nos fundamentos da Biologia Sistêmica. Em vista da abundância de dados públicos de expressão gênica para o organismo e do objetivo primário, um objetivo secundário foi traçado: identificar, computacionalmente, genes de fato controlados pelas interações fornecidas pela nova rede. Para isso, a estrutura estabelecida foi transformada numa Rede Bayesiana, e a identificação de genes foi efetuada através da análise de suas Tabelas de Probabilidade Condicionais. Finalmente, como os resultados obtidos para o objetivo secundário foram desfavoráveis a utilização de Redes Bayesianas, os resultados efetivos deste trabalho foram a criação de uma nova Rede de Regulação Gênica para a H. salinarum e uma análise em torno da efetividade de Redes Bayesianas neste contexto.

Palavras-chave: Biologia Sistêmica, Redes de Regulação Gênica, Redes Bayesianas, Halobacterium salinarum NRC-1. 
The main goal of this work was modeling the gene regulatory network of the model organism Halobacterium salinarum NRC-1, establishing new interactions between network's entities through unpublished physical interaction experiments: ChIP-*, RIP-* e dRNA-seq. Instead of using classical approaches to build network structures that estimates interactions using gene expression data, this work established them exclusively from physical interactions. Therefore, the final structure is a more reliable representation of the physical phenomenon of gene expression, built using the principles of systems biology. Considering the amount of public available gene expression data and the primary goal, another objective was proposed: a computational analysis to detect genes actually controlled by the interactions of the new network. To achieve this goal the established network was transformed in a Bayesian network, detecting genes through the analysis of their conditional probability tables. Lastly, as the results of the secondary goal went against the use of Bayesian networks, the effective results of this thesis were the creation of a new genetic regulatory network for H. salinarum and an analysis around Bayesian networks in this context. Key-words:

systems biology, genetic regulatory networks, bayesian networks, Halobacterium salinarum NRC-1. 

INTRODUÇÃO ...................... 1

2 REDES DE REGULAC̣ÃO GÊNICA . . . . . . . . . . . . . 4

$2.1 \quad$ Halobacterium salinarum NRC-1 . . . . . . . . . . . . . . . . 4

$2.1 .1 \quad$ Regulação da expressão gênica . . . . . . . . . . . . . . . . . 7

$2.2 \quad$ Redes de Regulação Gênica . . . . . . . . . . . . . . . . . . . . . 15

2.2.1 Redes de co-expressão . . . . . . . . . . . . . . . . . . 16

2.2.2 Equações Diferenciais Ordinárias . . . . . . . . . . . . . . . . . 16

$2.2 .3 \quad$ Redes Booleanas . . . . . . . . . . . . . . . . . . 17

2.2.4 Redes Bayesianas e Bayesianas Dinâmicas . . . . . . . . . . . . . . . . 20

2.2.5 Redes de interação Proteína-Proteína . . . . . . . . . . . . 25

2.2.6 Aprendizado da estrutura . . . . . . . . . . . . . . 26

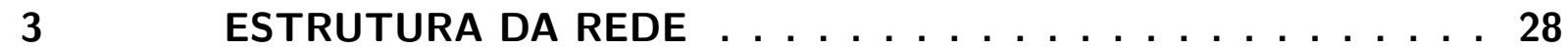

3.1 Descrição experimental . . . . . . . . . . . . . . 28

3.2 Obtenção dos dados . . . . . . . . . . . . . . . 35

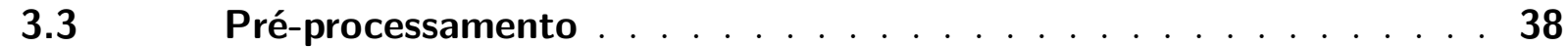

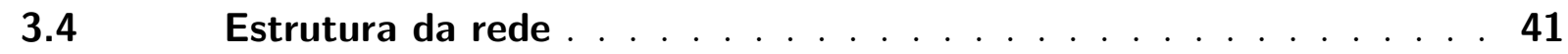

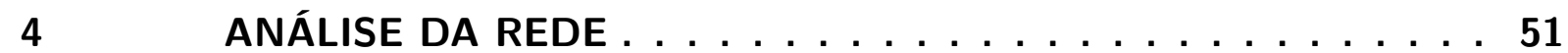

$4.1 \quad$ Descrição experimental . . . . . . . . . . . . . . . 51

4.2 Obtenção e processamento dos dados . . . . . . . . . . . . . . 54

4.3 Tabelas de Probabilidade Condicionais . . . . . . . . . . . . . . 57

5 CONCLUSÃO E PERSPECTIVAS . . . . . . . . . . . . . 64

A H. SALINARUM: ANÁLISE MICROARRAY . . . . . . . . 66

B MYCOBACTERIUM TUBERCULOSIS: ANÁLISE . . . . . . . 69

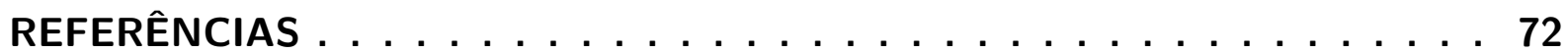


Figura 2.1 - Árvore Filogenética Universal . . . . . . . . . . . . . . . . . 5

Figura 2.2 -Halobacterium salinarum NRC-1 . . . . . . . . . . . . . . 6

Figura 2.3 - Habitat da H. salinarum . . . . . . . . . . . . . . . . . . . . . . 7

Figura 2.4 - Dogma Central da Biologia Molecular . . . . . . . . . . . . . . . . . . 9

Figura 2.5 - Maquinaria de transcrição e tradução em procariotos . . . . . . . . . . 11

Figura 2.6 - Mecanismo de regulação em arquéias e eucariotos . . . . . . . . . . . . 12

Figura 2.7 -Redes Booleanas . . . . . . . . . . . . . . . . . . . . . 18

Figura 2.8 - Rede Booleana Probabilística . . . . . . . . . . . . . . . . . . . 19

Figura 2.9 - Rede Bayesiana Sprinkler . . . . . . . . . . . . . . . . . . . . . . 22

Figura 2.10-Rede Bayesiana Dinâmica . . . . . . . . . . . . . . . . . . . . 24

Figura 3.1 - Protocolo ChIP-on-chip. . . . . . . . . . . . . . . . . . . . . 31

Figura 3.2 - Protocolo RIP-seq. . . . . . . . . . . . . . . . . . . . . . . 32

Figura 3.3 - Exemplo de visualização com dados de H. salinarum na ferramenta GGB 35

Figura 3.4 - Perfil de sinal . . . . . . . . . . . . . . . . . . . . . . . . . . . . . 39

Figura 3.5 - Segmentos de sinal obtidos no processamento RIP-seq . . . . . . . . . . 40

Figura 3.6 - Critério de interação ChIP_* . . . . . . . . . . . . . . . . . . . 43

Figura 3.7 - Rede resultante do processamento ChIP-* . . . . . . . . . . . . . . . 44

Figura 3.8 - Critério de interação dRNA-seq. . . . . . . . . . . . . . . . . . . . . . 45

Figura 3.9 - Rede resultante do processamento ChIP-* e dRNA-seq . . . . . . . . . 46

Figura 3.10-Rede resultante do processamento ChIP-*, dRNA-seq e RIP-seq . . . . 47

Figura 3.11-Rede resultante do processamento ChIP-*, dRNA-seq, RIP-seq e interações proteicas . . . . . . . . . . . . . . . . . . . . . . 48

Figura 3.12-Rede de Regulação Gênica proposta para a H. salinarum . . . . . . . . 50

Figura 4.1 - Principais etapas do experimento microarray. . . . . . . . . . . . . . 53

Figura 4.2 - Tipos de posicionamento para sondas de tiling array. . . . . . . . . . . 54

Figura 4.3 - Exemplo de BN utilizada na análise probabilística . . . . . . . . . . . 58

Figura 4.4 - Genes classificados como controlados pelos reguladores propostos. . . . 63

Figura A.1-Exemplo de rede apresentando a simplificação adotada para a estrutura original. . . . . . . . . . . . . . . . . . 67 67

Figura A.2-Genes classificados como controlados pelos reguladores propostos. . . . 67

Figura B.1-Genes classificados como controlados pelos reguladores propostos. . . . 71 
Tabela 2 - Dados de ChIP-chip e ChIP-seq para Halobacterium salinarum NRC-1. 36 Tabela 3 - Dados de tiling array para Halobacterium salinarum NRC-1. . . . . . . 55

Tabela 4 - Exemplo de CPT representando a regulação do gene VNG1830G. . . . 60 Tabela 5 - Exemplo de CPT identificada através da análise. . . . . . . . . . . 62 


\begin{tabular}{|c|c|c|}
\hline Símbolo & Descrição & Tradução \\
\hline $2 \mathrm{TBN}$ & two-time-slice Bayesian network & - \\
\hline asRNA & antisense RNA & RNA antisenso \\
\hline aTSS & antisense TSS & TSS antisenso \\
\hline $\mathrm{BN}$ & Bayesian network & Rede Bayesiana \\
\hline cDNA & complementary DNA & DNA complementar \\
\hline ChIP-chip & $\begin{array}{l}\text { chromatin immunoprecipitation with } \\
\text { DNA microarray }\end{array}$ & $\begin{array}{c}\text { Imunoprecipitação de cromatina } \\
\text { com DNA microarray }\end{array}$ \\
\hline ChIP-seq & $\begin{array}{l}\text { chromatin immunoprecipitation with mas- } \\
\text { sively parallel DNA sequencing }\end{array}$ & $\begin{array}{c}\text { Imunoprecipitação de cromatina } \\
\text { com Sequenciamento Paralelo } \\
\text { Massivo }\end{array}$ \\
\hline circRNA & circular RNA & RNA circular \\
\hline CPD & conditional probability distribution & $\begin{array}{l}\text { Distribuição de Probabilidade } \\
\text { Condicional }\end{array}$ \\
\hline $\mathrm{CPT}$ & conditional probability table & $\begin{array}{c}\text { Tabela de Probabilidade } \\
\text { Condicional }\end{array}$ \\
\hline DAG & directed acyclic graph & Grafo Acíclico Direcionado \\
\hline $\mathrm{DBN}$ & dynamic Bayesian network & Rede Bayesiana Dinâmica \\
\hline DNA & deoxyribonucleic acid & ácido desoxirribonucleico \\
\hline dRNA-seq & differential RNA sequencing & - \\
\hline EGRIN & $\begin{array}{l}\text { Environment and Gene Regulatory Influ- } \\
\text { ence Network }\end{array}$ & - \\
\hline GRN & gene regulatory network & Rede de Regulação Gênica \\
\hline GTF & general transcription factor & Fator de Transcrição Geral \\
\hline
\end{tabular}


\begin{tabular}{ll} 
Símbolo & Descrição \\
\hline iTSS & internal TSS
\end{tabular}

LFDR local false discovery rate

LSm like Sm proteins

miRNA micro RNA

MLE maximum likelihood estimation

mRNAs messenger RNA

NChIP native ChIP

ncRNA non-coding RNA

NGS next-generation sequencing

PBN probabilistic Boolean network

PIC preinitiation complex

PPI protein-protein interaction network

pTSS primary TSS

RBo Boolean network

RIP-seq RNA immunoprecipitation with sequencing

RNA ribonucleic acid

RNA-seq RNA sequencing

RNAP RNA polymerase

rRNA ribosomal RNA

sotRNA sense overlapping transcripts RNA

sRNA small RNA

TBP TATA binding protein

$\mathrm{TF} \quad$ transcription factor

tRNA transfer RNA

TSS transcription start site

TSSaRNA transcription start site associated RNA
Tradução

TSS interno

proteínas LSm

micro-RNA

Estimativa de Máxima

Verossimilhança

RNAs mensageiros

RNA não-codificante

Sequenciamento de Nova Geração

Rede Booleana Probabilística

Complexo de pré-iniciação

Rede de interação

proteína-proteína

TSS primário

Rede Booleana

Imunoprecipitação de RNA com

sequenciamento paralelo massivo

ácido ribonucleico

Sequenciamento de RNA

RNA polimerase

RNA ribossômico

pequeno RNA

proteína de ligação TATA

Fator de Transcrição

RNA transportador

Sítio de Início da Transcrição

RNA associado ao Sítio de Início da Transcrição 
Símbolo Descrição

Tradução

XChIP cross-linked ChIP 
Esta dissertação tem dois objetivos principais: apresentar a Rede de Regulação Gênica do organismo Halobacterium salinarum NRC-1 e analisar as probabilidades, em estado estacionário, associadas aos nós da rede. O primeiro objetivo tem como motivação estabelecer novas interações a partir de dados experimentais inéditos, podendo revelar importantes mecanismos de regulação do organismo, diferenciando-se das estruturas já existentes por incluir relações extraídas através de dados experimentais inéditos de dRNAseq (differential RNA sequencing) e RIP-seq (RNA immunoprecipitation sequencing).

Um diferencial fundamental deste trabalho é a forma escolhida para estabelecer interações entre os nós da rede. Enquanto os trabalhos tidos como referência para a estrutura de redes gênicas deste organismo [1,2] baseiam-se em medições realizadas em dados de diversas origens, majoritariamente de expressão gênica via mRNAs, esta dissertação tem como proposta utilizar apenas dados experimentais de interação física (ou evidências fortes indiretas destas) entre os nós. Apesar de restringir a quantidade de dados, as relações inferidas serão mais condizentes com a mecanística do fenômeno da regulação gênica, contrapondo-se a dificuldade encontrada em estabelecer relações biologicamente significativas através de medidas de níveis de expressão de RNAs (i.e. microarrays ou RNA-seq).

Grande parte deste trabalho só foi possível devido aos avanços produzidos pelo projeto de sequenciamento do genoma humano, que alterou profundamente o futuro da ciência, revolucionando não só o estudo da Biologia e sim diversas outras áreas que se encarregariam de processar e analisar uma quantidade de dados nunca vista em Biologia Molecular. A geração massiva de dados, por sua vez, foi proporcionada graças aos avanços realizados na última década em tecnologias de sequenciamento de larga escala, gerando dados que passaram de centenas de megabytes para milhares de gigabytes.

Todas as medições utilizadas para estabelecer a estrutura da rede foram baseadas em tecnologias que empregam diretamente os chips de microarray ou o sequenciamento paralelo massivo. Especificamente, as interações entre os nós da rede foram estabelecidas através de medições obtidas das seguintes técnicas: ChIP-chip (Imunoprecipitação de cromatina), ChIP-seq, RIP-seq e dRNA-seq. As três primeiras fazem parte do conjunto de 
tecnologias de imunoprecipitação, responsável por precipitar proteínas de interesse através de anticorpos específicos, identificando sequências associadas a estas proteínas que serão posteriormente sequenciadas e medidas. Os protocolos ChIP-* (ChIP-chip e ChIP-seq) e RIP-seq correspondem a aplicação da imunoprecipitação nas moléculas de DNA e RNA, respectivamente. Já o protocolo dRNA-seq é utilizado para identificar sítios de início de transcrição, não tendo relação alguma com a imunoprecipitação.

Cada uma destas tecnologias de medição foi empregada com o objetivo de modelar o fenômeno biológico de controle pré e pós-transcricional da regulação gênica. Os experimentos ChIP-* tiveram como alvo as proteínas conhecidas como Fatores de Transcrição (abreviados aqui por TF). Estas proteínas são responsáveis por regular o nível de transcrição dos genes, sendo uma importante forma de controle pré-transcricional, agindo diretamente no controle do nível de expressão, realizado geralmente através da combinação de múltiplos TFs. Os TFs podem ser divididos em dois subconjuntos: os gerais, associados a transcrição basal dos genes, e os específicos, úteis em condições específicas de estresse, sendo ambos fundamentais para o controle pré-transcricional da expressão.

Enquanto o controle pré-transcricional é responsável pelo ajuste dos níveis de transcrito de forma global, o controle pós-transcricional está, em geral, associado ao fino ajuste da transcrição. Dois exemplos de mecanismos de controle pós-transcricional são a interação da proteína LSm com RNAs e a interação de transcritos antisenso com mRNAs.

A família de proteínas LSm pertence ao grupo das chaperonas, ubíquas na natureza, são encontradas nos três domínios da vida, estando envolvidas em mecanismos fundamentais relacionados ao arranjo do RNA, como: decaimento e splicing do mRNA, processamento do RNA e regulação antisenso da expressão gênica [3]. Além disso, resultados obtidos para a Hfq [4] (a proteína homóloga a LSm mais comumente encontrada nas bactérias) e também para a LSm na H. salinarum [5] sugerem sua importância nos mecanismos de regulação pós-transcricional, desta forma, incluir tais interações, obtidas através do experimento RIP-seq, é fundamental para o objetivo deste trabalho.

O papel de transcritos antisenso na regulação está associada a interação destes com os da fita senso, já que devido à total complementariedade dos transcritos ocorre a hibridação (ou pareamento) entre os mesmos, alterando a estrutura secundária de ambos e resultando na formação de uma estrutura duplex (fita dupla de RNA). Um efeito conhecido destas alterações é a diminuição da meia vida de dos RNAs, resultando na degradação rápida e completa de ambos [6]. O potencial de interação dos transcritos antisenso e seus mRNAs será inferido indiretamente através do dRNA-seq. O caráter indireto está associado a natureza do experimento, já que este não mede interações físicas, permitindo apenas a não dentificação de prováveis potenciais de interação entre transcritos antisenso e seus mRNAs.

Outra fonte de dados utilizada para estabelecer interações na rede será a base 
de dados STRING [7], responsável por disponibilizar livremente interações proteicas para vários organismos. As associações são estabelecidas computacionalmente através da combinação de diferentes dados, oriundos de múltiplos experimentos e agrupados num modelo matemático que fornece uma probabilidade da interação ocorrer. Devido à decisão metodológica de nos ater exclusivamente a experimentos que lidam com interação física, as predições obtidas computacionalmente não serão consideradas.

O segundo objetivo deste trabalho refere-se a tentativa de predizer os estados dos genes presentes na rede exclusivamente a partir de seus reguladores conhecidos. Para isso, a rede estabelecida na primeira etapa será simplificada, adotando o modelo de Redes Bayesianas para avaliar a probabilidade de um gene estar num estado específico condicionado aos estados de seus reguladores. A utilização deste modelo possibilitará a análise das probabilidades dos nós em estado estacionário, que serão avaliadas em três estados representativos, "-1", "0" e "+1", calculados através da discretização dos dados de tiling array também disponíveis. As principais vantagens desta abordagem são sua fácil interpretação, graças ao caráter probabilístico da análise e também a capacidade do modelo de representar uma quantidade arbitrária de estados.

Finalmente, eis uma apresentação a respeito do conteúdo desta dissertação. No Capítulo 1 introduziu-se o problema e os objetivos da dissertação. O Capítulo 2 contém a descrição do organismo para qual a rede de regulação será construída, a Halobacterium salinarum NRC-1 e um breve resumo histórico da área em que a solução computacional se baseou, as Redes de Regulação Gênica. O Capítulo 3 trata dos dados experimentais utilizados para construção da estrutura da rede, ChIP-*, RIP-seq e dRNA-seq. Introduz resumidamente cada um dos protocolos; apresenta como foram obtidos e pré-processados para o método desenvolvido; e finalmente os resultados obtidos da aplicação deste método. O Capítulo 4 trata dos dados de expressão gênica utilizados. Inicialmente apresentando uma descrição sobre o microarray e tiling array; como estes dados foram obtidos; os detalhes de pré-processamento e como serão utilizados; apresenta o método utilizado para calcular as tabelas de probabilidade; apresentando por último os resultados da análise das tabelas. Por último, o Capítulo 5 encerra esta dissertação com as conclusões e perspectivas do projeto. 


\section{Redes de Regulação Gênica}

Nesta seção, os principais conceitos teóricos e a revisão bibliográfica utilizadas serão apresentadas. A seção "Halobacterium salinarum NRC-1" descreve o organismo foco deste trabalho, apresentando tanto características específicas quanto gerais do seu gênero. Na seção "Redes de Regulação Gênica" serão apresentados os modelos matemáticos comumente utilizados na modelagem de GRNs, após a revisão dos modelos também serão apresentados métodos que "aprendem" a estrutura da rede a partir de dados.

\subsection{Halobacterium salinarum NRC-1}

O final da década de 1970 foi responsável por dar inicio a uma revolução que alteraria para sempre a forma com que organismos vivos seriam classificados, tendo como principal ponto de partida o trabalho do físico Carl R. Woese e do engenheiro químico George E. Fox [8]. O gatilho desta revolução foi a possibilidade de analisar informações contidas nas sequências genômicas dos organismos, graças ao recém desenvolvido sequenciamento de Sanger. Woese baseou-se principalmente nesta tecnologia para argumentar que a classificação dominante (eucariotas e procariotos) deveria ser substituída por uma nova, que considerasse a informação histórica (filogenética) entre os organismos, já que segundo Woese, Kandler e Wheelis [9] "O problema desta classificação surge porque o conceito de Eucariontes-Procariontes é fundamentalmente citológico, e somente de forma secundária filogenética, o que até faz sentido para os eucariotas, que compartilham estruturas similares, mas de forma alguma para os procariotos, que estão agrupados simplesmente por não possuírem estruturas eucariontes" - referindo-se ao então modelo dominante. Woese, estudando bactérias metanogênicas identificou semelhanças destes organismos tanto com eucariotas quanto procariotos, o que o levou a supor que outros organismos com as mesmas características deveriam existir, apesar de ainda não serem conhecidos, e, portanto, faria sentido agrupá-los num novo domínio, o das Archaebacterias (Terminologia atualizada para Archaea) [8]. Desde a proposta, outros organismos com semelhanças citológicas com os procariotos (ausência de membrana limitando o conteúdo nuclear) e molecular com os eucariotas (cromossomo com mais de uma origem de replicação) foram descobertos, confirmando a previsão de Woese e tornando necessário a criação de um novo domínio para agrupá-los, estabelecendo o domínio Archaea como uma nova divisão da vida (Figura 2.1). 
Do ponto de vista evolutivo, vale destacar a semelhança das arquéias com os outros dois domínios. A maior parte dos genes de um organismo é responsável por controlar suas vias metabólicas. No caso das arquéias estes genes tem maior relação com os procariotos, enquanto os genes responsáveis por controlar a expressão, mais similares aos eucariotas. Como dito previamente, a estrutura celular é muito semelhante com a dos procariotos, mais especificamente com as bactérias gram-positivas, já que ambas possuem uma dupla bicamada lipídica [10]. A hipótese mais aceita para explicar a diversificação destas então bactérias gram-positivas em arquéias está relacionada ao papel da pressão seletiva de antibióticos nestes seres; o principal argumento desta suposição baseia-se na observação de que as arquéias são resistentes a vários antibióticos produzidos justamente por bactérias gram-positivas. Desta forma, a pressão ambiental proporcionou uma série de mutações em genes alvos destes antibióticos, originando uma cepa ancestral das arquéias conhecidas atualmente $[11,12]$.

Já a relação com os eucariotas ainda não é clara, existindo duas hipóteses concorrentes. A primeira afirma que os eucariotas divergiram cedo das arquéias, tendo surgido através da fusão das últimas com as eubactérias, tal que o núcleo era composto pela parte relativa as arquéias e o citoplasma pela eubactéria [13]. A segunda, que é a hipótese do eócito, afirma que os eucariotas divergiram a partir dos Crenarchaeota (um filo do domínio Archaea), baseando-se no fato de que o RNA-ribossomal destes seres e dos eucariotas são mais semelhantes entre si do que entre outros organismos, sendo o principal contraponto à teoria de Woese e Fox [8] dos três domínios. Conseguir estabelecer uma teoria sobre o surgimento dos eucariotas se mostra difícil, tendo em vista que o fóssil mais jovem já encontrado apresenta 1,8 bilhões de anos, tempo mais do que suficiente para que as sucessivas mutações no DNA e consequentemente nas proteínas transcritas erradicasse quaisquer semelhanças existentes $[14,15]$.

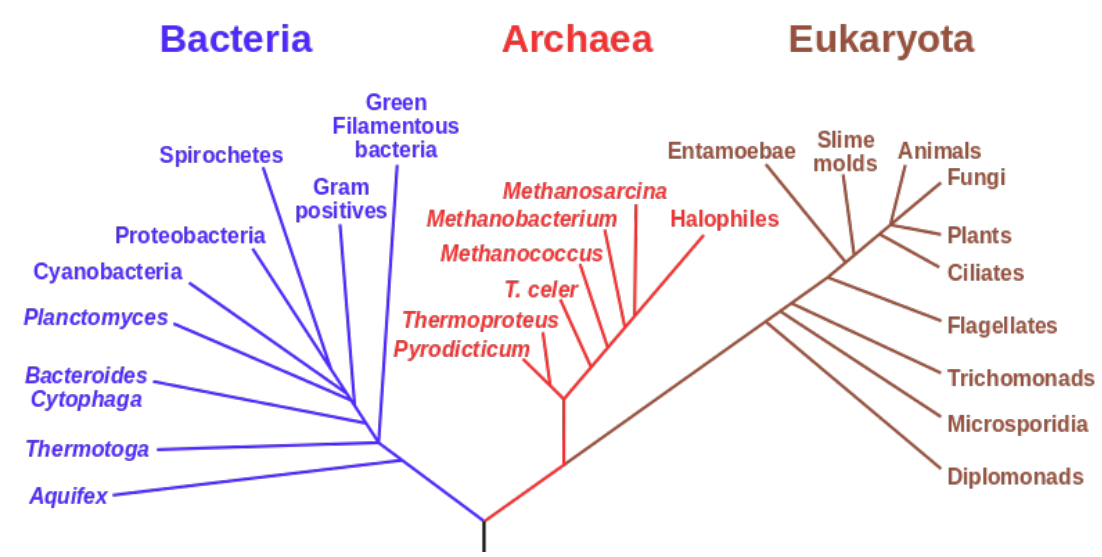

Figura 2.1 - Árvore Filogenética Universal, criada a partir do método proposto por Woese, Kandler e Wheelis [9] que compara sequências de rRNA. Fonte: <https://en.wikipedia.org/wiki/ Phylogenetic_tree>. 
Uma classe de interesse do domínio Archaea são as Halobactérias, extremófilos que vivem em altas concentrações de sal, de cinco a dez vezes maiores que a do mar, o que os tornam atrativos como organismos extremófilos modelo, tendo em vista a facilidade de replicar tal ambiente num laboratório. Para DasSarma et al. [16] "Estudos clássicos das Haloarchaeas contribuíram de forma significativa para o nosso entendimento dos mecanismos de adaptação, assim como características fundamentais da vida", atribuindo como principais contribuições destes organismos a descoberta da camada-S da parede celular [17] e a composição da membrana celular por lipídeos de éter de cadeia ramificada [18].

De forma geral, as Halobactérias compartilham características que começaram a ser descobertas a partir do sequenciamento de seus respectivos genomas, apresentando um cromossomo principal com conteúdo $\mathrm{G}+\mathrm{C}$ relativamente acima de $60 \%$ e replicons com conteúdo $\mathrm{G}+\mathrm{C}$ levemente menor. A Figura 2.2(a) apresenta o micro-organismo, enquanto a Figura 2.2(b) um cristal de sal onde a H. salinarum foi encontrada (motivo do cristal ser rosado).

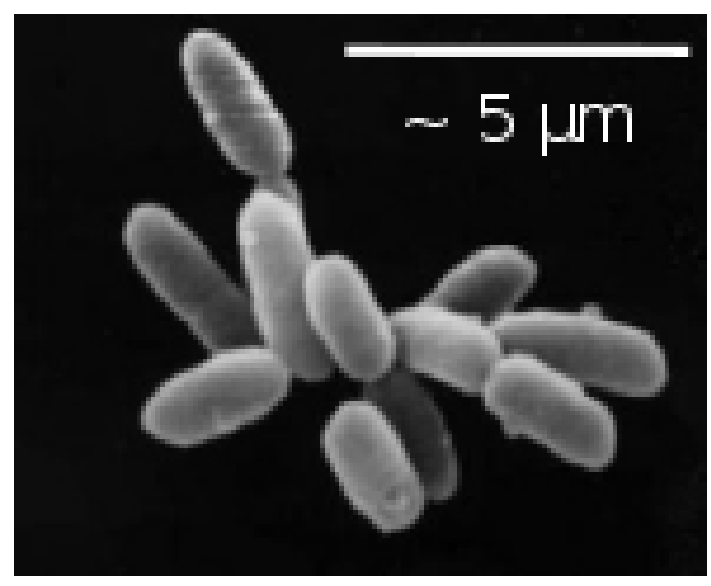

(a)

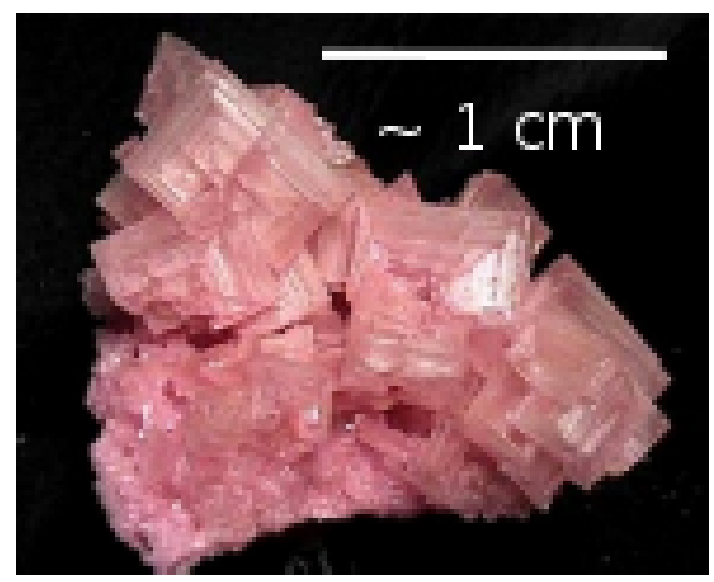

(b)

Figura 2.2 - Halobacterium salinarum NRC-1. (a) Microscopia eletrônica da H. salinarum NRC1. (b) Uma halita contendo H. salinarum, encontrada no lago Searles, na Califórnia. Fontes: $<$ https://microbewiki.kenyon.edu/index.php/Halobacterium $>,<$ http://www.webmineral.com/ data/Halite.shtml>

O principal organismo modelo das Halobactérias é a Halobacterium salinarum NRC1, representada na Figura 2.2(a), um dos primeiros descobertos neste domínio, encontrado em 1930 num pedaço de pele de búfalo curado com sal ${ }^{1}$. Desde então, enormes esforços foram despendidos para compreender seus mecanismos de regulação, tendo sido a primeira Halobactéria a ter seu genoma completamente sequenciado [19], tornando-se popular, e recebendo cada vez mais atenção de pesquisadores interessados em utilizar um organismo modelo cujo mecanismo de regulação fosse mais similar aos eucariotas. O genoma da H. salinarum tem um tamanho de $\sim 2,6 \mathrm{Mpb}$, contendo $\sim 2.600$ genes não redundantes, divididos num cromossomo principal, de $\sim 2 \mathrm{Mpb}$ e dois replicons, pNRC100 com $\sim 190$

1 <https://en.wikipedia.org/wiki/Halobacterium_salinarum> 
kpb e pNRC200, com $\sim 360 \mathrm{kpb}$, todos circulares, e como esperado, com genes essenciais localizados nos plasmídios.

Alguns habitats típicos das H. salinarum são o Mar Morto, Great Salt Lake, cristais de sal (Figura 2.2(b)) e de forma geral ambientes aquosos com alta concentração de sal $(\sim 4,3 \mathrm{M})$. Nestes ambientes é possível verificar que a coloração da água assume um tom rosado, similar ao da Figura 2.3(a), mais forte ou fraco a depender da quantidade de organismos. A coloração é devido à presença da proteína Bacteriorrodopsina, presente na membrana plasmática e responsável por captar energia solar para mover prótons para fora da membrana, transformando o gradiente em energia química. Além disso, também apresentam vesículas gasosas - Figura 2.3(b) - que permitem que o organismo flutue, otimizando sua absorção de energia solar [20].

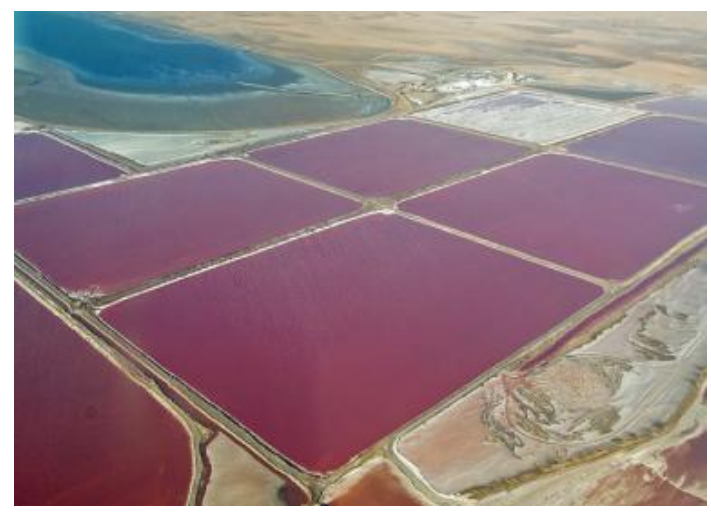

(a)

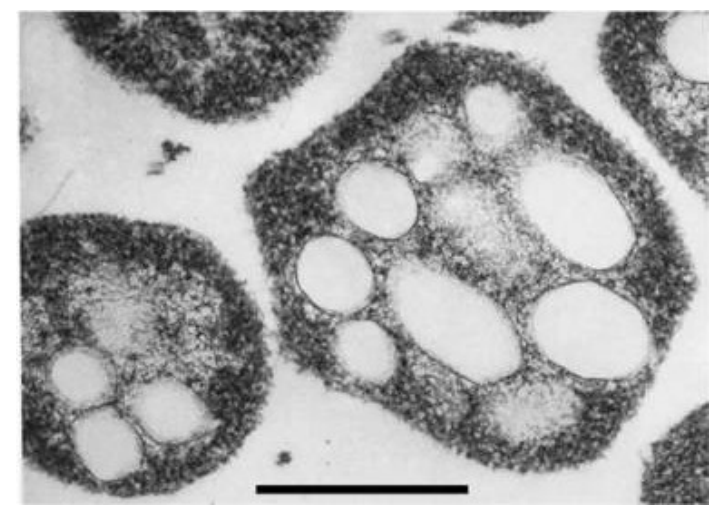

(b)

Figura 2.3 - Habitat típico da H. salinarum. (a) Visão aérea de uma Salina na Namíbia, habitat típico de Halobactérias. A coloração do lago é devido à produção da proteína Bacteriorrodopsina, presente na membrana plasmática das Halobactérias e responsável por transformar luz solar em energia química. (b) Microscopia eletrônica das vesículas de gás da H. salinarum. Fontes: <http: //media.ellerstrand.se/2013/11/5_Cities02-800x450.jpg > e adaptado de DasSarma et al. [20]

Como a GRN da H. salinarum será construída utilizando dados de interações físicas (ou proxis dela), torna-se mandatório realizar uma descrição sobre os mecanismos de regulação das arquéias e em específico na $H$. salinarum, apresentando primeiramente a regulação nos procariotos, por ser a mais simples, a dos eucariotas, mais complexa, e por fim a das arquéias, fornecendo paralelos entre as mesmas.

\subsubsection{Regulação da expressão gênica}

O ácido desoxirribonucleico (DNA) é a molécula mais fundamental à maioria dos seres vivos, armazenando informações genéticas que serão transmitidas aos seus descendentes. A molécula foi resolvida pelo biólogo James Watson e o físico Francis Crick, que constataram que a então "nova" molécula era composta por quatro subunidades básicas, repetidas milhões de vezes para formar a molécula que receberia o nome de DNA. 
Os nucleotídeos são as subunidades básicas que compõem o DNA, formadas através da ligação de uma pentose e um fosfato em conjunto com uma das quatro bases nitrogenadas: Adenina (A), Guanina (G), Timina (T) e Citosina (C). O DNA é composto por duas "fitas", cada uma contendo milhares de repetições destas quatro unidades básicas. A ligação entre se dá através formação de pontes de hidrogênio entre purinas ( $\mathrm{A}$ e $\mathrm{G}$ ) e pirimidinas $(\mathrm{C}, \mathrm{G})$, mais especificamente entre as seguintes moléculas: A,T e C,G. As propriedades físico-químicas destas ligações dão a forma da estrutura amplamente conhecida do DNA, a dupla hélice.

Não obstante terem sido os primeiros a resolver a estrutura desta molécula, o que alteraria para sempre o futuro da Biologia, também foram os primeiros a propor um mecanismo explicando o fluxo de informação num organismo vivo. Este importante conceito é conhecido como o Dogma Central de Biologia, que estabelece o fluxo da informação de maneira unidirecional, do DNA a proteína Figura 2.4.

A molécula de DNA tem duas funcionalidades, replicação e transcrição. A replicação é o mecanismo responsável pela transmissão da informação armazenada. Já a transcrição está associada a transformação da informação armazenada em mensagens. O produto deste processo é uma molécula intermediária, conhecida como mRNA (ácido ribonucleico mensageiro). À época da criação desta hipótese, esta era a principal molécula de RNA conhecida, entretanto, com o passar dos anos outros tipos foram sendo descobertos, como o rRNA (RNA ribossômico), tRNA (RNA transportador), e os ncRNA (RNA não codificante), etc. Cada RNA atua de forma específica na transformação da mensagem intermediária numa proteína, no processo conhecido como tradução. O resultado desta etapa gera como produto um polipeptídeo, que formará uma proteína ou parte dela, e que de fato é responsável por executar a ação contida na mensagem. As proteínas são as principais moléculas que realizam ações num organismo.

Este fluxo de informação também pode ser compreendido pela ideia de moldes, onde o DNA serve de molde para ele mesmo na síntese de novas moléculas de DNA (replicação), assim como para moléculas mensageiras (transcrição), que por sua vez são utilizadas na síntese de proteínas (tradução). Entretanto, esta proposta de fluxo da informação num sistema biológico vem sendo desafiada insistentemente, através de novas descobertas como o papel dos ncRNAs no controle da regulação e a já bem conhecida transcriptase reversa, que permite transformar a mensagem novamente numa molécula de DNA. Todavia, apesar deste modelo não ser totalmente condizente com o conhecimento corrente, ainda é uma boa aproximação para a maioria dos processos.

Um fato presenciado nos três domínios é que a regulação do nível de expressão de um gene (quantidade de "comandos" produzidos), ocorre, na maioria das vezes, antes da transcrição, fato que pode ser justificado sob à luz da evolução, já que um organismo que detêm capacidade de interromper o processo de transcrição é muito mais eficiente do ponto 


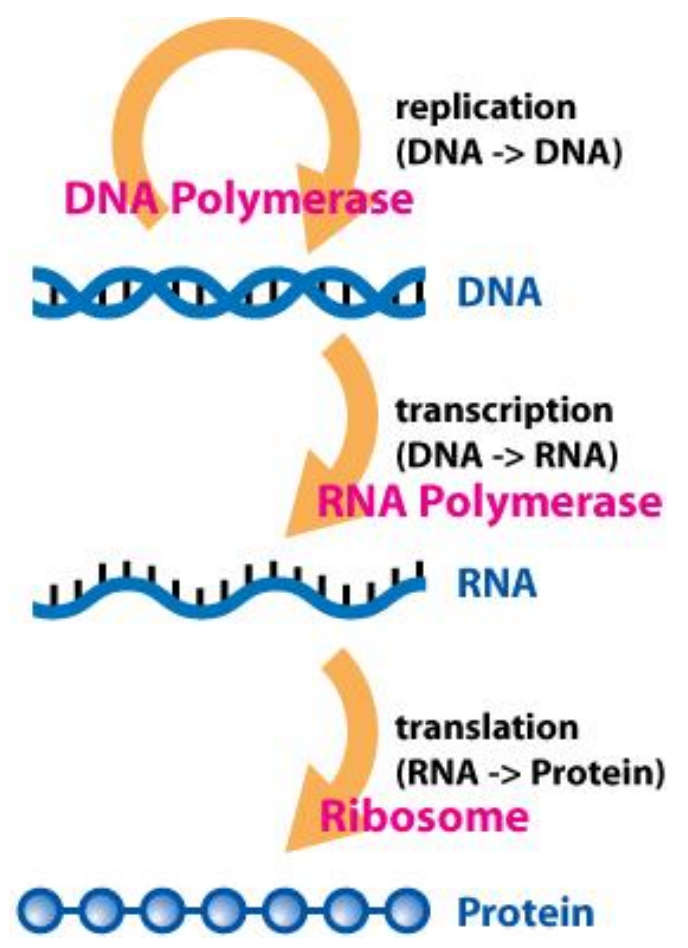

Figura 2.4 - Dogma Central da Biologia Molecular. O DNA armazena informação genética essencial a replicação, que através da ação da DNA polimerase transmite hereditariedade aos sucessores; a segunda etapa é resultante da ação da RNA polimerase, responsável por transcrever a informação presente no DNA numa molécula de RNA, representando um comando que deverá ser realizado; finalmente, os ribossomos traduzem o mRNA em proteína, transformando o comando numa ação. Fonte: <https://en.wikipedia.org/wiki/Central_dogma_of_molecular_biology>.

de vista energético que outro que controla a quantidade de transcritos após a produção dos mesmos. Esta forma de controle recebe o nome de regulação pré-transcricional, ou simplesmente transcricional, e apesar de ser o tipo mais comum, não é a única existente. Outra maneira de realizar o controle da quantidade de "comandos" é após sua transcrição, degradando ou impedindo de alguma forma que as moléculas mensageiras sejam transformadas em ações, sendo conhecido como controle pós-transcricional.

Em se tratando de controle transcricional, um grupo de proteínas ligantes ao DNA desempenha papel fundamental no controle da quantidade de mRNAs produzidos. Conhecidos como fatores de transcrição (mais conhecido em inglês como transcription factor), são proteínas que contém no mínimo dois domínios proteicos, um responsável por ligar-se ao DNA e outro a fatores alostéricos, que são moléculas originárias do metabolismo celular, sendo, portanto, um sítio responsável por identificar mudanças no ambiente celular. O controle na regulação é promovido pelas alterações físicas proporcionadas pela ligação com o DNA, atuando como promotores ou repressores, recrutando ou não a RNA polimerase (RNAP). Nas arquéias e eucariotas estas proteínas formam um complexo responsável pela transcrição basal dos genes, i.e., alguns TFs (básicos) em conjunto com a RNAP formam o chamado complexo de pré-iniciação da transcrição (mais conhecido em inglês como preinitiation complex - PIC), que tem como função transcrever genes a uma 
taxa constante, sendo necessário a ligação de TFs específicos (em alguns casos sensíveis a alterações ambientais) para elevar os níveis de transcrição aos níveis máximos ou mínimos, a depender do TF. Estes TFs ditos básicos são tão importantes para a vida que receberam o nome de Fatores de Transcrição Gerais (GTF), sendo encontrados em células humanas, de Drosophila, em Saccharomyces cerevisiae, etc [21], sempre envolvidos com o mecanismo de transcrição basal.

Apesar das particularidades dos mecanismos de regulação em cada um dos domínios, uma semelhança importante em todos é o papel da RNAP, proteína responsável pela transcrição da região codificante do gene, transformando a informação genética em componentes ativos na regulação do organismo. É evidente que os procariotos possuem uma RNAP mais rudimentar em termos evolutivos do que as arquéias e os eucariotas, entretanto, apesar das mutações ocorridas durante a evolução um fato permaneceu imutável, a necessidade de associação da RNAP com moléculas capazes de reconhecer as regiões promotoras dos genes. A associação da RNAP com a região de transcrição de interesse é mediada pelos GTFs, que posicionam a RNAP próximo a região de início de transcrição. Após a associação da RNAP a região promotora, tem início a transcrição, resultando num mRNA que será traduzido em proteína. Os mecanismos específicos de cada domínio serão apresentados a seguir.

Os procariotos controlam a transcrição de todos os seus genes a partir de uma única RNAP, constituída de duas subunidades $\alpha$, uma $\beta$ e outra $\beta^{\prime}$, além de um fator $\sigma$ (sigma) (único GTF necessário aos procariotos), responsável por reconhecer regiões promotoras. Os fatores sigma são moléculas responsáveis por reconhecer a região promotora de conjuntos de genes, desempenhando papel fundamental na maquinaria transcricional, posicionando a RNAP na região $[-35,-10]$ do TSS (sítio de início da transcrição). Existem distintos fatores sigma $\left(\sigma^{19}, \sigma^{19}, \sigma^{70}\right.$, etc), cada qual especializado em reconhecer um conjunto de genes. Entretanto, o simples mecanismo de especificidade do fator sigma não pode explicar o sucesso adaptativo destes seres nas mais diferentes condições ambientais, fornecendo evidências para a provável existência de outros dispositivos que adicionem complexidade a regulação. Esta adaptabilidade pode ser explicada através dos fatores de transcrição, que são proteínas capazes de induzir ou reprimir a expressão gênica, ligando ou desligando-se do sítio operador do gene, bloqueando ou não de forma física o deslocamento da RNAP.

A Figura 2.5 apresenta o mecanismo de transcrição e tradução dos procariotos, ilustrando de forma simplificada como os diferentes níveis de expressão necessários em diferentes condições ambientais são obtidos. A Figura 2.5(a) apresenta o posicionamento da RNAP (realizado pelo GTF $\sigma$-factor), a presença de um TF específico repressor impede que a RNAP "leia" a região codificante do gene. Com a alteração do estado ambiental ocorre a ligação de um fator alostérico a um sítio do TF repressor, fazendo com que o 


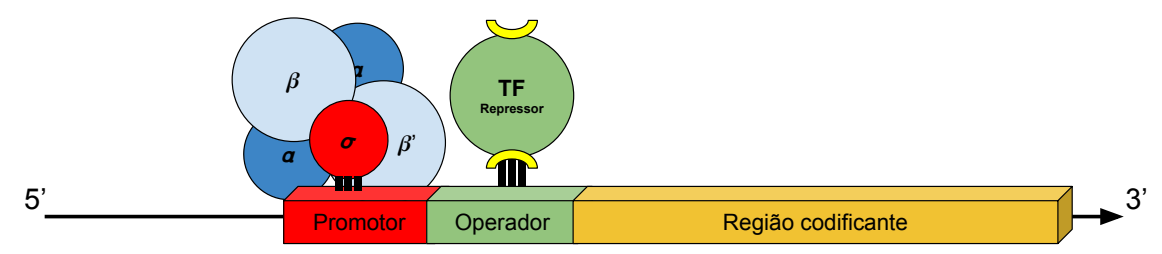

(a) Maquinaria transcricional em procariotos.

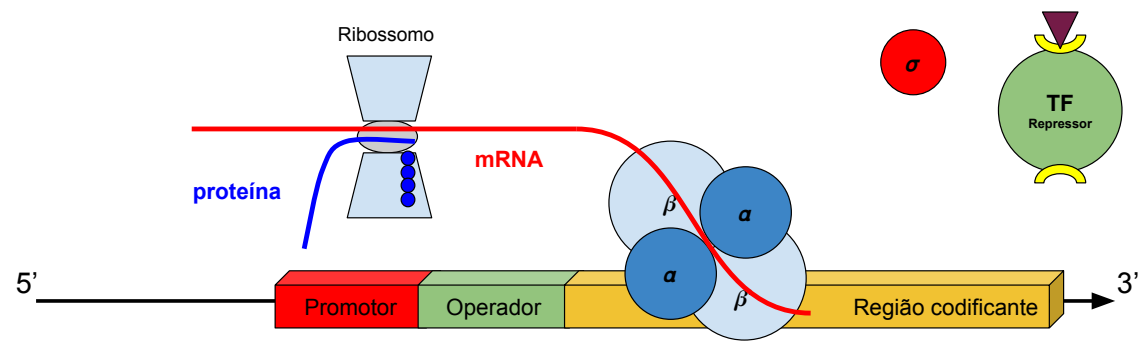

(b) Maquinaria transcricional e traducional em funcionamento.

Figura 2.5 - Maquinaria de transcrição e tradução em procariotos. (a) A RNAP liga-se a região promotora através do fator $\sigma$. A transcrição terá início quando o TF repressor for removido da região operadora. (b) A liberação da região promotora através da conexão de um fator alostérico ao sítio do TF permitiu que a RNAP iniciasse a transcrição, produzindo mRNA (em vermelho) que está sendo traduzido pelo ribossomo simultaneamente a transcrição, gerando um início de proteína (em azul). Fonte: Adaptado de [22].

mesmo deixe a região operadora Figura 2.5(b). Não existindo mais nenhuma limitação física a RNAP, o $\sigma$-factor desassocia-se do complexo e a RNAP liga-se diretamente ao DNA, iniciando a transcrição que resultará numa molécula de mRNA (em vermelho). Por último, o mRNA começa a ser processado pelos ribossomos, que traduzirão o mRNA numa proteína (em azul).

Tentativas de reproduzir o mecanismo de transcrição dos eucariotas ocorreram quando a Biologia Molecular ainda dava seus primeiros passos, ficando evidente através de experimentos in vitro que o mecanismo de transcrição não dependia exclusivamente da RNA polimerase II, e sim de um conjunto adicional de proteínas [21]. Além disso, ficou claro que a mecânica da transcrição manteve-se similar a dos procariotos, mas especializando e adicionando novos mecanismos capazes de lidar com a maior complexidade dos organismos. A coluna à direita da Figura 2.6 apresenta as principais etapas da transcrição nos eucariotas. Os eucariotas não apresentam uma única RNAP, existindo diversas variações responsáveis por transcrever genes específicos, diferente dos procariotos onde a RNAP transcreve tanto mRNA quanto ncRNA. A RNAP-II é a responsável por transcrever os genes codificadores de proteínas, e similar aos procariotos também não é capaz de reconhecer sozinha as regiões promotoras dos genes, que contêm diferentes regiões consenso, cuja representante mais conhecida nos eucariotas é a TATA-box. Aqui a transcrição também tem início com a ligação de uma proteína que cuja função é ligar-se ao DNA (TFIID), conhecida como TBP (TATA binding protein) Figura 2.6(a). Com a ligação da TBP ocorre o recrutamento da 
TFIIB - Figura 2.6(b) - que terá como papel recrutar outros TFs necessários a transcrição. A Figura 2.6(c) apresenta todos os GTFs e a RNAP-II, formando o PIC. Como última etapa ocorre a desnaturação do DNA, permitindo que a RNAP-II "leia" os nucleotídeos e os transcreva em mRNA.

Diferente dos procariotos, a tradução nos eucariotas não ocorre simultaneamente a transcrição, tendo em vista a própria organização celular distinta entre ambos. A transcrição nos eucariotas é localizada fisicamente no núcleo celular, enquanto a tradução no citoplasma, existindo a necessidade de transporte dos mRNAs até o citoplasma, onde os ribossomos traduzirão os mesmos em proteína (assumindo que nenhum controle pós-transcricional interfira).
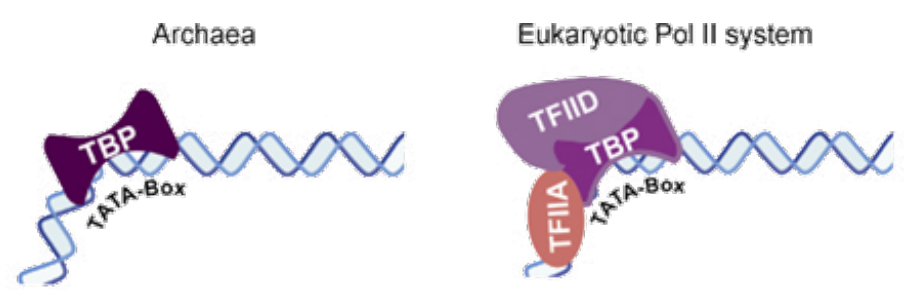

(a)
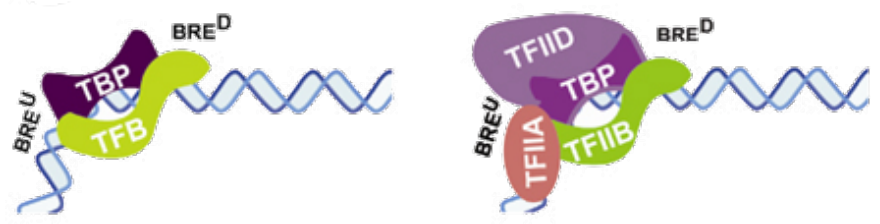

(b)
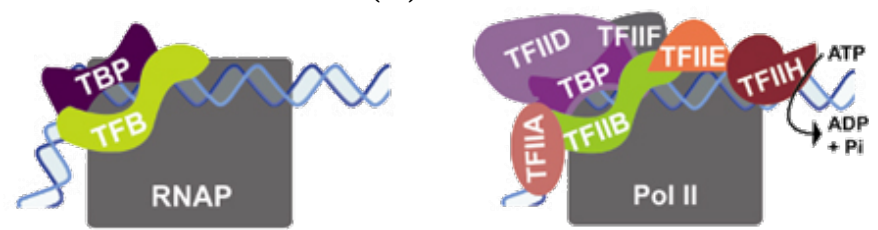

(c)
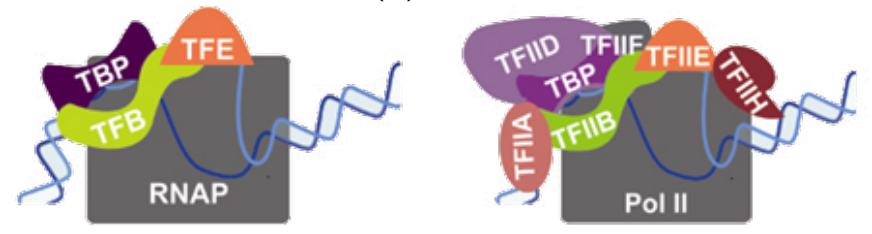

(d)

Figura 2.6 - Mecanismo de regulação em arquéias e eucariotos. A figura à esquerda apresenta as etapas necessárias para a transcrição de um gene nas arquéias enquanto a da direita apresenta as etapas necessárias para a transcrição de um gene nos eucariotas. (a) Ligação do TBP ao DNA (TATA-Box). (b) Ligação do TFIIB (TFB nas arquéias), responsável por recrutar a RNAP e outros TFs básicos. (c) Ligação da RNAP e de todos os TFs necessários para a transcrição basal, formando o PIC. (d) Desnaturação da fita de DNA através da ação do TFIIE (TFE) e consequente início de transcrição. Fonte: <http://www.uni-regensburg.de/biologie-vorklinische-medizin/mikrobiologie/ team-leaders/thomm/research/ $>$.

As arquéias apresentam um mecanismo de transcrição que detêm similaridades tanto com os eucariotas como com os procariotos, o que faz sentido, já que se acredita que 
elas sejam um ancestral comum dos eucariotas que divergiu de bactérias gram-positivas [23]. Assim como os procariotos, a transcrição é mediada por uma única RNA-polimerase, mas diferente, os fatores sigma são substituídos por três TFs ortólogos dos eucariotas, TBP (uma subunidade do TFIID nos eucariotas), TFIIB (do inglês, transcription factor II) e TFE (subunidade do TFIIE nos eucariotas), formando uma versão mais simplificada do PIC eucarioto, conforme apresentado à esquerda da Figura 2.6. As etapas para o início da transcrição são iguais as já apresentadas aos eucariotas, tendo como única diferença a menor quantidade de TFs associados a maquinaria, sendo vista como uma versão simplificada da PIC eucariota. É interessante notar que várias espécies de arquéias produzem diferentes isoformas das proteínas TBP e TFB, existindo resultados que sugerem que diferenças nos níveis de transcrição podem estar associados a ligação destes pares de isoforma as regiões promotoras [24], o que pode ser interpretado como uma reminiscência evolutiva dos fatores sigma nas bactérias.

Geralmente o papel completo dos GTFs é relativamente desconhecido em organismos complexos como seres humanos, entretanto, nos mais simples é possível determinar o papel dos mesmos em condições ambientais específicas. O trabalho de Facciotti et al. [25] avaliou o papel das seis e sete isoformas de TBP e TFB, respectivamente, da $H$. salinarum em condições ideais de crescimento. Através de experimentos de expressão gênica e de interação proteica com o DNA, foi possível concluir que somente cinco dos treze GTFs existentes são essenciais para a H. salinarum em condições ideais do laboratório, o que não implica de forma alguma que as outras isoformas presentes não são necessárias em condições específicas. Em relação aos TFs específicos existentes nas arquéias, o trabalho de Karr [26] apresenta uma revisão descrevendo o papel e em quais condições os TFs conhecidos até o momento são necessários.

O conhecimento existente sobre os mecanismos de tradução nas arquéias ainda é pequeno quando comparado aos outros domínios. Antes que os primeiros estudos fossem realizados, acreditava-se que os arquéias apresentariam um mecanismo de tradução igual ao das bactérias, tendo em vista a semelhança fenotípica. Semelhança que foi de fato confirmada a medida que os primeiros dados de estudos traducionais foram disponibilizados, entretanto, para surpresa de todos, descobriu-se que alguns mRNAs nas arquéias eram dotados de sequências de Shine-Delgardo (mais conhecido em inglês por motif SD) antes dos códons de iniciação, desta forma, facilitando o alinhamento do ribossomo com o códon de iniciação do mRNA. Com outros genomas sendo sequenciados, foi possível confirmar que existiam dois mecanismos distintos de início da tradução nas arquéias: um bacteriano, baseado em motivos SD e, portanto, operando nos cístrons internos de mRNAs policistrônicos, e outro, de natureza desconhecida, empregado para iniciar a tradução de cístrons leaderless [27]. Um fato interessante sobre mRNAs leaderless é que eles aparentam ser universalmente traduzíveis, independente de sua origem, pelos ribossomos de Procariotos, Eucariotos e Arquéias, fornecendo evidências de que este mecanismo não é 
um híbrido, mas sim uma forma muito antiga e ainda operante nos três domínios da vida.

De acordo com Jun et al. [28] "para sobreviver de forma efetiva num ambiente competitivo é necessário, ao mesmo tempo, balancear a produção gênica necessária para manter as atividades celulares e também evitar a produção de proteínas desnecessárias. A regulação da expressão gênica tem potencial para ocorrer em qualquer etapa, desde o início da transcrição até a degradação da proteína. A regulação no início da transcrição é a etapa mais importante da expressão gênica e, portanto, os organismos desenvolveram uma variedade de métodos para atingir um resultado efetivo", deixando evidente que apesar de mais comum, a regulação ao nível transcricional não é a única existente. Apesar de não serem os únicos mecanismos de controle pós-transcricional, este trabalho deu atenção a duas interações muito importantes e amplamente estudadas: a ligação de RNAs antisenso (asRNA) com mRNAS; e de proteínas ligantes ao RNA com moléculas de mRNA, ambas as principais novidades do modelo proposto por este trabalho.

Segundo Pelechano e Steinmetz [29], apesar dos transcritos antisenso em bactérias terem sido descobertos há mais de trinta anos, apenas graças aos avanços introduzidos, na última década, nas abordagens genômicas, é que foi possível descobrir que este mecanismo estava presente nos genomas das mais diferentes espécies. Os asRNA são classificados como RNAs não codificantes (ncRNAs), um grupo de RNAs que não codificam proteínas, estando diretamente envolvidos no controle da expressão gênica efetuada através do pareamento das bases com o mRNA alvo (cis) ou através da alteração da atividade de proteínas (trans) [30].

Os cis-RNAs são transcritos na mesma região gênica do seu alvo, interagindo na regulação gênica através do pareamento dos nucleotídeos de sua fita com o mRNA produzido na fita oposta, consequentemente impedindo a continuidade da transcrição devido a complementariedade das fitas. O papel dos asRNA na regulação gênica vem recebendo atenção ao ponto de ser indicado como principal motivo para as diferenças evolucionarias existentes entre os humanos e os primatas, hipótese reforçada pela substancial quantidade de transcritos antisenso identificados em regiões codificadores de proteínas [6]. O trabalho de Babski et al. [31] é uma boa revisão apresentando o levantamento histórico e apontando possíveis funcionalidades para os asRNAs nas arquéias, além de citar que de forma geral o papel dos asRNAs nas bactérias está associado ao "ajuste fino" da regulação gênica, uma vez que mutantes com o gene asRNA deletado não sofreram alterações claras no fenótipo quando comparadas com a cepa original.

Já os trans-RNAs são codificados em regiões distantes e por não apresentarem complementariedade com seus alvos, atuam através da ligação em proteínas. Dentre as proteínas que se ligam a RNAs (RBP do inglês $R N A$ binding protein) um grupo que merece atenção é o das chaperonas, responsáveis por alterar a estrutura secundária das moléculas de RNA e expor corretamente os sítios de interação dos ncRNAs com seus alvos. 
A família de proteínas LSm pertence a este grupo, ubíquas na natureza, são encontradas nos três domínios da vida, estando envolvidas em mecanismos fundamentais relacionados ao arranjo do RNA, como decaimento e splicing do mRNA, processamento do RNA, regulação antisenso da expressão gênica, etc [3].

A H. salinarum codifica uma única proteína LSm ( [5]), atuando diretamente no controle do metabolismo energético e na resposta ao estresse oxidativo, fato comprovado experimentalmente através de dados RIP-seq utilizados no presente trabalho. Outra conclusão do trabalho foi a detecção de interações da LSm com todos os rRNAs e 10 tRNAs da H. salinarum, fornecendo, em conjunto com [32], fortes evidências do papel ativo da LSm na regulação das arquéias. A LSm também interage com outros ncRNAs: TSSaRNAs, circRNAs e sotRNAs, evidenciando função similar a da Hfq nas bactérias, onde a degradação do mRNA e a facilitação da interação de sRNAs com seus antisensos são alguns papéis conhecidos desta proteína.

\subsection{Redes de Regulação Gênica}

A Biologia Sistêmica tem como objetivo modelar a fisiologia de um organismo de forma global. Esta visão só foi possível graças ao desenvolvimento de tecnologias de medição de larga escala, possibilitando avaliar a dinâmica das moléculas de forma abrangente. De acordo com Barabasi e Oltvai [33], a visão reducionista de um único componente celular e suas funcionalidades dominaram a pesquisa biológica por mais de um século, entretanto, hoje é conhecido que raramente o comportamento de um mecanismo pode ser explicado através de uma única molécula, e este é o principal desafio da Biologia moderna, ser capaz de compreender as complexas interações da dinâmica intracelular.

Um modelo sistêmico que desperta grande atenção são as redes de Regulação Gênica (mais conhecida em inglês como gene regulatory network - GRN). Seu objetivo é proporcionar uma visão global da fisiologia do organismo, revelando os mecanismos de controle através de uma visão de organismo como um "todo" e não partes separadas. Jong [34] aponta que a representação de GRNs através de grafos direcionados e acíclicos é a abordagem mais natural de modelagem, representando os genes ou elementos de interesse do problema como os nós, e as arestas como relações regulatórias entre os mesmos. Esta modelagem ignora, por exemplo, mecanismos de regulação tipo feedback, entretanto estas e outras simplificações são necessárias devido à alta complexidade do problema, de tal forma que a utilização destes modelos matemáticos seja uma aproximação útil do problema real. Nas subseções seguintes, os principais modelos de GRNs encontrados na literatura serão apresentados. 


\subsubsection{Redes de co-expressão}

Redes de correlação (co-expressão) são modelos onde as interações entre os genes são estabelecidas através de uma medida de interesse (correlação, informação mútua, euclidiana, etc) entre seus respectivos níveis de expressão. Uma particularidade deste modelo é sua incapacidade de representar relações causais, razão pela qual algumas referências não consideram este paradigma como uma GRN. As interações entre os genes são estabelecidas caso a medida entre o par de genes seja maior que um limiar arbitrário. A maneira adotada pelo modelo para estabelecer as interações nos remete imediatamente a representação empregada por grafos não direcionados [35], uma vez que converter a matriz contendo as medições dos pares de genes para um grafo é uma tarefa trivial.

A principal razão para modelar o fenômeno físico da regulação gênica através deste modelo é sua simplicidade computacional, uma vez que os recursos necessários para calcular e armazenar as medidas são muito baixos quando comparados aos outros modelos, especialmente considerando a escassez de amostras biológicos. Apesar dos benefícios computacionais, existem críticas sobre o "poder" representativo do fenômeno físico, principalmente no que está relacionado ao emprego de medidas que não são capazes de incorporar o conhecimento biológico do problema. A correlação, por exemplo, só consegue medir interações entre pares de genes, fato que é raramente verdadeiro na Biologia, onde as vias metabólicas são reguladas por relações altamente complexas. Outro problema associado a correlação é que um valor alto desta medida não implica que um gene interage com o outro (correlação não implica causalidade).

Outra razão frequentemente apontada como uma desvantagem deste modelo é sua incapacidade de incorporar relações temporais, o que de forma alguma condiz com o fenômeno físico modelado, mas que é geralmente assumida para simplificar a modelagem [36].

\subsubsection{Equações Diferenciais Ordinárias}

O uso de equações diferenciais possibilita uma maior flexibilidade na modelagem, tendo em vista dois principais fatores: a possibilidade de trabalhar com dados contínuos (o que pode ser um problema, se considerada a quantidade de dados necessários para estimar os parâmetros); e a capacidade de modelar interações não-lineares entre as entidades, através de equações diferenciais não-lineares.

Desta forma, as interações neste modelo são representadas de acordo com Equa- 
ção $2.1[36]$.

$$
\left\{\begin{aligned}
\frac{d x_{1}}{d t} & =\sum_{j=1}^{N} w_{1, j} \cdot x_{j}+b_{1} \cdot \mu \\
\frac{d x_{2}}{d t} & =\sum_{j=1}^{N} w_{2, j} \cdot x_{j}+b_{2} \cdot \mu \\
& \vdots \\
\frac{d x_{N}}{d t} & =\sum_{j=1}^{N} w_{N, j} \cdot x_{j}+b_{N} \cdot \mu
\end{aligned}\right.
$$

Onde $x_{i}, \mu$ e $w_{i, j}$ representam, respectivamente, os diferentes genes envolvidos no fenômeno, qualquer perturbação ambiental existente e os coeficientes associados aos genes presentes na equação. Assim, para qualquer gene $x_{i}$, seu nível de expressão será dado por uma combinação linear entre os outros nós da rede. Vale notar que este sistema contínuo pode ser facilmente aproximado por Equações de Diferenças, um procedimento muito útil, dado a natureza dos experimentos disponíveis para realizar medições de expressão gênica.

Desta forma, a maior dificuldade deste modelo é inferir os parâmetros a partir das medições disponíveis. De forma geral, o problema de estimação dos parâmetros exige uma quantidade de dados inexistente para a maioria dos organismos, principalmente se equações não-lineares forem utilizadas (o que geralmente não ocorre [34]). Entretanto, apesar das limitações, trabalhos como $[37,38]$ utilizam equações diferenciais para inferir a GRN. No primeiro trabalho, a metodologia proposta só consegue trabalhar com redes contendo apenas três genes, enquanto a segunda, no máximo dez. Como consequência este modelo caiu em desuso, dado que o objetivo de modelar GRNs é justamente descobrir relações de regulação globais e não apenas de uma quantidade pequena de genes.

\subsubsection{Redes Booleanas}

Introduzido através do trabalho de Kauffman [39], é considerado um dos modelos mais simples (do ponto de vista biológico) e ainda assim, capaz de capturar importantes características a respeito do comportamento dinâmico do organismo [40]. Numa Rede Booleana (mais conhecida em inglês como Boolean network - RBo) cada gene é representado por dois estados possíveis, 0 e 1 . Onde geralmente "1" significa ligado e "0", desligado, i.e., o gene está sendo transcrito ou não. Assim como outros modelos que serão apresentados a seguir, a RBo é considerada um modelo direcionado, ou seja, o sentido das setas ligando os genes da rede têm significado, que no modelo Booleano representa a dependência temporal da variável.

Um importante aspecto de uma RBo é seu comportamento dinâmico, ou seja, o estudo sobre a transição de seus estados ao longo do tempo, existindo duas formas de se realizar a atualização dos estados. A primeira é de forma síncrona e todos os nós da rede são atualizados simultaneamente, o que de modo algum representa o que ocorre num 
organismo, mas é uma simplificação necessária para possibilitar a análise da dinâmica do sistema [41]. Outra forma de atualizar os nós da rede é de maneira assíncrona, mais fiel ao problema biológico, mas ao mesmo tempo de difícil tratamento computacional, tendo em vista a enorme quantidade de estados possíveis a serem avaliados $\left(2^{n}\right.$, onde $n$ é o número de genes). Durante a evolução do sistema alguns estados podem não ser atingidos nunca, enquanto outros periodicamente (atratores), dependendo do estado inicial. Segundo Liang, Fuhrman e Somogyi [42], "atratores podem ser vistos como estados alvo de um organismo, i.e., tipos celulares ao fim do desenvolvimento ou até mesmo a adaptação da expressão metabólica de um gene mediante a mudança de nutrientes no ambiente de uma bactéria", tornando a detecção de estados atratores uma das principais motivações para criação de redes de regulação.

Uma RBo sintética contendo três genes é apresentada na Figura 2.7(a), onde é possível verificar que o estado de cada gene é dado através de uma função cujo comportamento depende exclusivamente da combinação de operadores booleanos e o valor de expressão do gene num instante de tempo anterior, como ilustrado pelas funções $F_{A}, F_{B}$, e $F_{C}$ presentes na figura. Exemplos reais de RBo na construção de GRNs podem ser encontrados na Figura 2.7(b), que apresenta a GRN da Schizosaccharomyces pombe, e em [43], que apresenta o comportamento dinâmico de uma via metabólica da Saccharomyces cerevisiae.

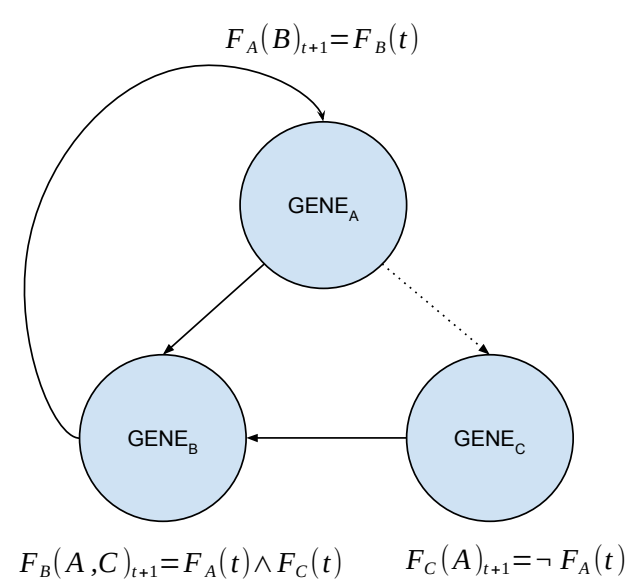

(a)

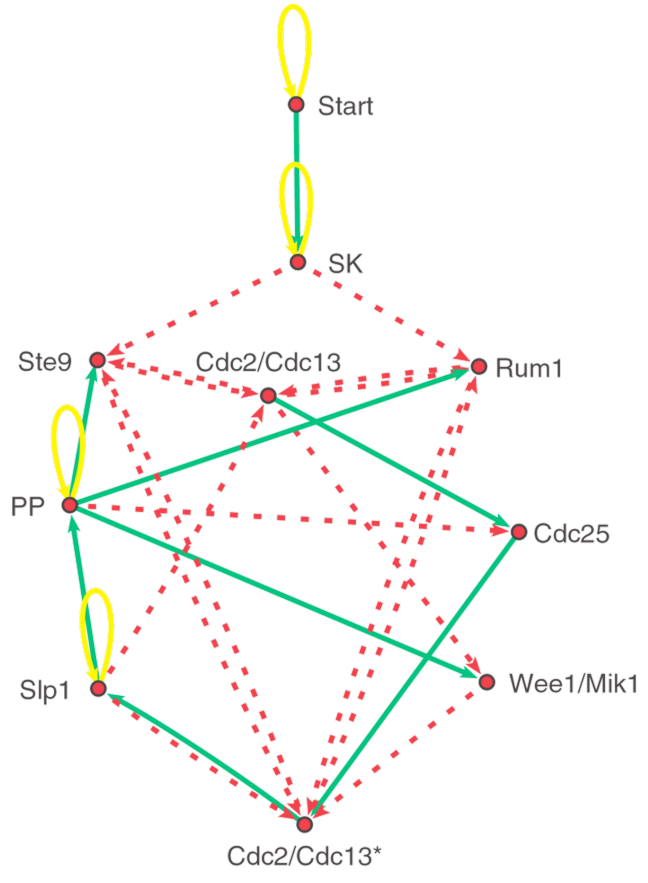

(b)

Figura 2.7 - Redes Booleanas. (a) Rede Booleana artificial representando interações entre três nós. (b) Via metabólica da Schizosaccharomyces pombe representada por uma Rede Booleana. Fonte: Davidich et al. [44].

Uma extensão do modelo Booleano é a adição de comportamento estocástico, associando múltiplas funções regulatórias a cada um dos arcos existentes, i.e., a cada 
transição uma função de regulação será escolhida probabilisticamente. Considerar que as funções de regulação não são determinísticas faz sentido do ponto de vista biológico, além de estar de acordo com o fato que geralmente o verdadeiro mecanismo de regulação do gene é desconhecido, não existindo sequer conhecimento a priori do pesquisador. Dois modelos se propõem a realizar a modelagem desta forma, as Redes Booleanas Probabilísticas (do inglês probabilistic Boolean network - PBN) [45] e as Redes Gênicas Probabilísticas [46].

Uma das principais limitações do modelo Booleano é o determinismo biológico associado as transições, já que o modelo assume que a função reguladora será sempre igual. Desta forma, as PBNs foram introduzidas para atacar esta limitação [45], não existindo mais uma única função associada ao nó, mas sim um conjunto; a seleção probabilística de um conjunto em cada instante de tempo representa melhor o fenômeno físico de interação e regulação entre os genes. Trabalhos atestando a utilidade e capacidade deste modelo revelar informações relevantes do organismo podem ser encontradas em [45, 47, 48].

A Figura 2.8 apresenta uma PBN exemplo, que tem como objetivo representar as transições possíveis entre três genes, cuja combinação de estados booleanos é representada pelos nós. Também é possível verificar o comportamento estocástico associado ao modelo, uma vez que para cada aresta existe uma probabilidade associada.

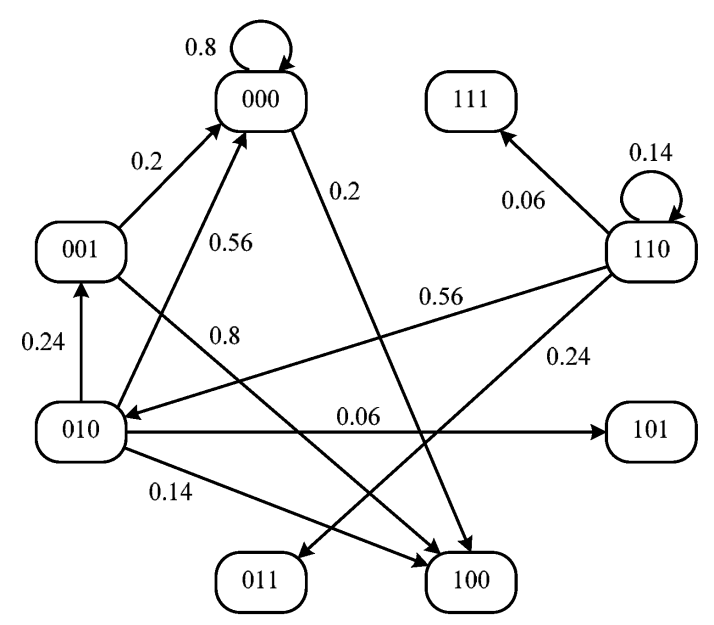

Figura 2.8 - Exemplo de Rede Booleana Probabilística. Cada um dos oito nós representa uma combinação entre os estados booleanos dos três genes modelados. Também é possível verificar o caráter estocástico do modelo, tendo em vista as probabilidades associadas as arestas, representando a transição probabilística entre os estados. Fonte: Kobayashi e Hiraishi [48].

A extensão probabilística permitiu a eliminação do comportamento determinístico do modelo, entretanto, ainda existe uma limitação importante, os estados estão restritos a on e off. Para combater esta limitação, as Redes Gênicas Probabilísticas (mais conhecida em inglês por probabilistic genetic network - PGN) foram propostas, generalizando os estados possíveis de um nó, não mais obrigatoriamente booleanos.

Formalmente, uma PGN $G=(X, \phi)$ com $n$ genes é definida através de um conjunto de nós $X=\left\{X_{i} \in R \mid i \in 1 \ldots n\right\}$ e um vetor de funções $\phi=\left(\phi_{1}, \phi_{2}, \ldots, \phi_{n}\right)$ com $\phi_{i}$ : 
$R^{k_{i}} \rightarrow R$, onde $k_{i}$ é o número de genes que regulam $X_{i}$. De forma geral, este modelo é uma cadeia de Markov-homogênea de primeira ordem, respeitando todos os axiomas necessários para ser considerada como tal. Assim, a função $\phi$ é invariante ao longo do tempo (homogênea) e depende exclusivamente dos valores de expressão num instante de tempo anterior (primeira ordem). A aplicação deste modelo em dados de Plasmodium falcíparum pode ser encontrada em [49].

\subsubsection{Redes Bayesianas e Bayesianas Dinâmicas}

Segundo Darwiche [50], Redes Bayesianas (mais conhecidas pelo termo, em inglês, Bayesian networks - BN) é um formalismo que busca representar o conhecimento de alguém sobre um domínio específico. Modelos que adotam este formalismo podem ser divididos em duas partes: qualitativa e quantitativa. A parte qualitativa é representada através de grafos acíclicos direcionados (mais conhecido em inglês como directed acyclic graph - DAG), onde os nós representam as variáveis de interesse ao problema e as arestas relações de dependência entre as mesmas. Uma interpretação natural desta estrutura é assumir relações de causalidade entre as variáveis, porém, apesar desta visão facilitar a compreensão, a definição de BNs é independente da noção de causalidade [51].

Como o modelo foi desenvolvido para representar crenças de um indivíduo sobre um problema, nada mais natural do que associar a estas relações medidas de probabilidade, portanto, a quantificação das relações existentes entre as variáveis é feita através de medidas de probabilidade. Uma vantagem deste modelo é a necessidade de definir apenas as probabilidades das variáveis conectadas por arestas, enquanto as influências indiretas sob a variável serão obtidas por algoritmos de inferência.

Existem três abordagens tipicamente utilizadas na construção de BNs durante a modelagem de um problema. A primeira forma, que é completamente subjetiva, baseia-se em modelar a rede a partir do conhecimento de um único indivíduo ou de um grupo, identificando as principais variáveis do problema e as probabilidades relacionadas aos eventos. A segunda refere-se a síntese de uma rede a partir de uma base de conhecimento formal, como por exemplo nas áreas de diagnóstico de sistemas, onde as decisões são obtidas através de decisões formais de design. Estas duas abordagens são conhecidas como "representação de conhecimento", existindo formalismos como a análise de sensitividade, capazes de analisar a robustez das probabilidades obtidas de forma relativamente subjetiva.

A terceira maneira de construir BNs se baseia em aprender a estrutura e as probabilidades a partir de dados, como registros médicos ou dados de expressão gênica. Estes princípios de indução de redes são baseados imensamente em aprendizado de máquina, tendo em vista a característica indutiva do problema. Grande parte dos métodos existentes nesta área são baseados em dois formalismos dominantes: estimativa de Máxima Verossimilhança (mais conhecido em inglês como maximum likelihood estimation - MLE) 
e abordagens Bayesianas. A abordagem por MLE resulta em redes que maximizam a verosimilhança de observação dos dados disponibilizados. Métodos Bayesianos tem a mesma proposta, com a diferença de permitir a adição de conhecimento a priori. Uma revisão mais completa a respeito de métodos de aprendizado da estrutura pode ser encontrada na subseção 2.2.6.

Seja $\mathcal{G}$ um DAG qualquer, as seguintes definições são válidas:

$$
\mathrm{Pa}(X)=\{y \in \operatorname{Pa}(X) \mid y \in \mathcal{G} \text { e seja um ancestral direto de } X\}
$$

$\operatorname{Desc}(X)=\{y \in \operatorname{Desc}(X) \mid y \in \mathcal{G}$ e seja um descendente direto de $X\}$

$$
\operatorname{NonDesc}(X)=\{y \in \operatorname{NonDesc}(X) \mid y \notin \operatorname{Pa}(X) \cup \operatorname{Desc}(X)\}
$$

Dado esta notação é possível formalizar a compactação obtida de uma modelagem através de BNs. Para uma BN qualquer, as relações representadas por este formalismo devem ser descritas por:

$$
X \Perp \operatorname{NonDesc}(X) \mid \operatorname{Pa}(X) \text { para todo } X \in \mathcal{G}
$$

Onde $X \Perp Z \mid Y$ significa que $X$ é independente de $Z$ dado $Y$. Desta forma, dado uma distribuição de probabilidade $P\left(x_{1}, x_{2}, \ldots, x_{n}\right)$ qualquer, uma BN é a decomposição desta distribuição em probabilidades condicionais do tipo $P(x \mid P a(x))$, facilmente demonstrável através da regra da cadeia das probabilidades que representa a distribuição original [51] (Equação 2.6).

$$
P\left(X_{1}, X_{2}, \ldots, X_{n}\right)=\prod_{X \in \mathcal{G}} P(X \mid \operatorname{Pa}(X))
$$

Para ilustrar as definições recém estabelecidas vale fazer uso de um exemplo clássico na literatura de BNs, a rede Sprinkler (Figura 2.9). O objetivo desta rede é modelar a probabilidade da grama estar molhada no período da manhã, mediante a existência de um sprinkler no gramado e a possibilidade de ter chovido na noite anterior.

As variáveis envolvidas no problema são Sprinkler, Rain e Grass e queremos decompor nosso conhecimento sobre a probabilidade deste evento ocorrer de forma compacta, através das dependências condicionais entre as variáveis. A Figura 2.9 apresenta um grafo contendo a decomposição da interpretação intuitiva do problema, i.e., o evento "choveu" $P(R)$ - não depende de nenhuma variável; já o evento "o sprinkler foi ligado" - $P(S)$ depende somente da quantidade de água no gramado (assumindo que não existem defeitos); por último, o evento "a grama está molhada" - $P(G)$ - depende, é claro, dos dois outros 


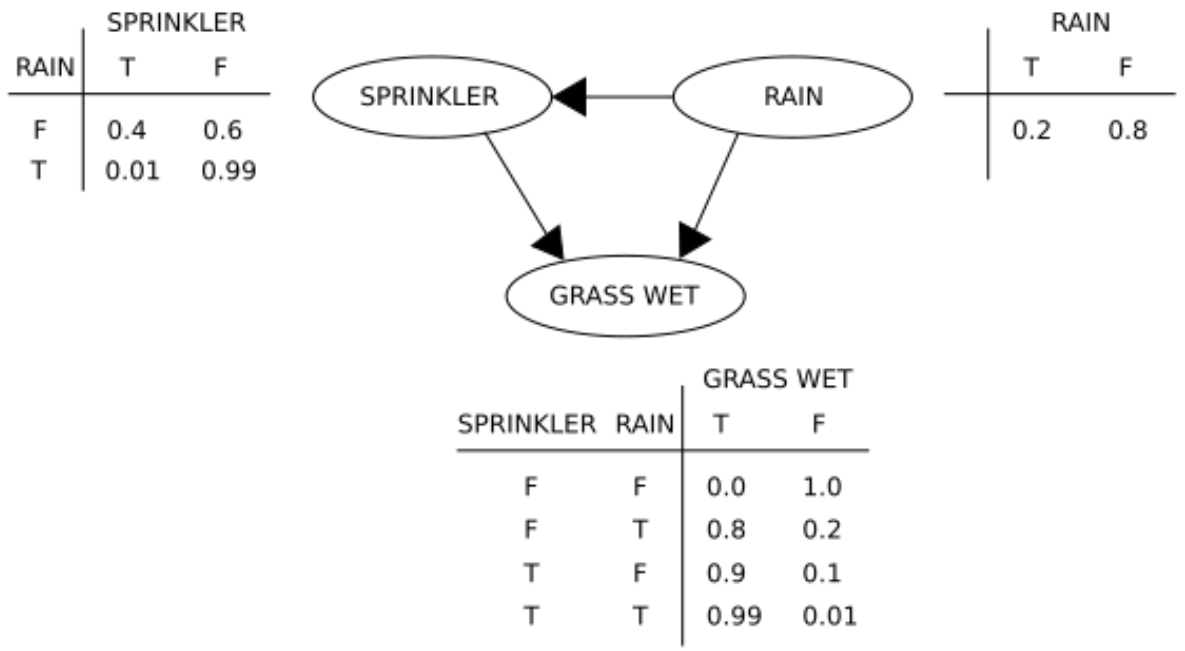

Figura 2.9 - Rede Bayesiana Sprinkler. Fonte: <https://en.wikipedia.org/wiki/Bayesian_ network\#/media/File:SimpleBayesNet.svg $>$.

eventos. Desta forma, as arestas existentes entre as variáveis representam relações de dependência condicional, tal que a variável $S$, por exemplo, é independente de $G$, dado que o estado de $R$ seja conhecido. Assim, seguindo as relações estabelecidas na figura, a probabilidade conjunta destes eventos é decomposta seguindo a Equação 2.7, onde todas as variáveis adotam a relação de independência da Equação 2.5. Neste exemplo, a prova de que a decomposição em probabilidades condicionais é válida pode ser realizada pela simples substituição das mesmas por suas respectivas definições.

$$
P(G, R, S)=P(G \mid R, S) P(S \mid R) P(R)
$$

Ao fazer uso de variáveis aleatórias discretas, como no exemplo, é comum representar a distribuição de probabilidade através de uma tabela de probabilidade condicional (mais conhecida em inglês como conditional probability table - CPT), apresentando a probabilidade da variável condicionada ao estado de seus pais, como, por exemplo, a CPT da variável "Grass" (localizada abaixo do nó "Grass Wet"), onde é possível verificar que $P(G=F \mid S=F, R=F)=1$, ou traduzindo em palavras: a probabilidade do evento "grama não estar molhada dado que o sprinkler não foi ligado e que não choveu" é igual a 1.

A representação através de CPTs é a mais comum, em grande parte por ser um recurso visual que permite a fácil visualização das probabilidades associadas a variável, entretanto, nem sempre é possível utilizá-la, uma vez que o caráter combinatório dos estados pode tornar a representação computacionalmente impraticável. É evidente que a representação através desta estrutura só é válida para variáveis aleatórias discretas, que apesar de serem mais comuns não são as únicas suportadas. Outras estruturas computacionais frequentemente utilizadas para representar variáveis discretas e contínuas 
de formas mais eficientes podem ser encontradas em [52].

Como citado no início desta seção, uma das maneiras mais naturais de representar GRNs é pelo uso de DAGs, característica que coloca as BNs a "frente" de outros modelos, em relação facilidade de interpretação, simplicidade de modelagem e ao número de aplicações. A facilidade de interpretação é resultante de seu caráter probabilístico, uma noção inerente a todos os seres humanos, principalmente tratando-se de estados discretos e finitos. Apesar de num primeiro momento a modelagem através de variáveis contínuas parecer mais promissora como representação do problema biológico, principalmente devido a não necessidade de estabelecer níveis de discretização (geralmente arbitrários), como no caso discreto, esta aparente vantagem logo se desfaz, uma vez que é possível representar apenas interações lineares entre variáveis contínuas (modelo gaussiano linear), o que de forma alguma se aproxima do problema biológico.

A simplicidade desta abordagem se dá principalmente devido à imediata incorporação de conhecimento a priori, sendo fácil, por exemplo, para uma pequena rede, estabelecer relações possivelmente corretas entre os nós e avaliar se as probabilidades obtidas através dos dados condizem com este conhecimento. Além disso, a necessidade de estabelecer exclusivamente relações do tipo $P$ (Proteína | Gene), simplificam a modelagem, tanto do ponto de vista computacional como científico.

Uma das primeiras aplicações de BN ao problema de GRNs pode ser encontrado em [53], neste trabalho, buscou-se encontrar a GRN da S. cerevisiae através do uso de métodos para aprendizado da estrutura, descobrindo interações gênicas antes desconhecidas e que se verificaram plausíveis através de experimentos posteriormente realizados. De forma geral, grande parte da literatura existente para GRNs baseadas em BNs, restringem-se apenas a utilização de métodos para o aprendizado da estrutura da rede [54]. Um trabalho que compara diferentes métodos para reconstrução de GRNs e em particular BNs é [55].

Um ponto negativo deste modelo é sua incapacidade de representar relações temporais e dependências cíclicas, que é o que de fato ocorre nos organismos e até mesmo nos dados de medição de expressão gênica (séries temporais), portanto, BNs são capazes somente de representar redes em estado estacionário. Uma alternativa desenvolvida para contornar este problema foi as Redes Bayesianas Dinâmicas (mais conhecida em inglês por dynamic Bayesian network - DBN).

Uma DBN é uma forma simples de representar um processo estocástico através de modelos gráficos direcionados, podendo ser considerado uma "simples" extensão de BN para lidar com dados temporais [56]. Apesar de seu nome, a estrutura e os parâmetros do modelo são fixos, seu caráter dinâmico se concentra em sua capacidade de lidar com interações fixas, mas que ocorrem ao longo do tempo.

A definição formal de DBNs é dada através da Equação 2.8, onde $\beta_{0}$ e $\beta \rightarrow$ represen- 
tam duas $\mathrm{BNs}$ - motivo pelo qual também é conhecida por 2TBN (do inglês two-time-slice Bayesian network). Mais especificamente, $\beta_{0}$ representa as interações entre as variáveis no estado estacionário, enquanto o modelo de transição $\left(\beta_{\rightarrow}\right)$, as interações temporais.

$$
\mathrm{DBN}=\left(\beta_{0}, \beta_{\rightarrow}\right)
$$

Novamente, para facilitar a compreensão do modelo, uma abordagem prática será adotada. A Figura 2.10 apresenta as duas redes necessárias para definir uma DBN.

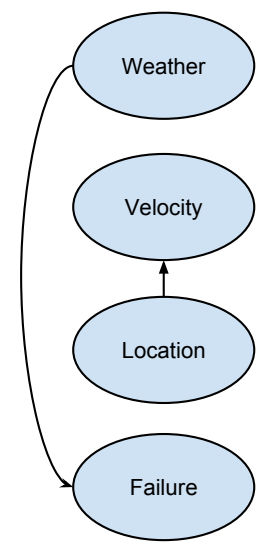

(a) $\beta_{0}$

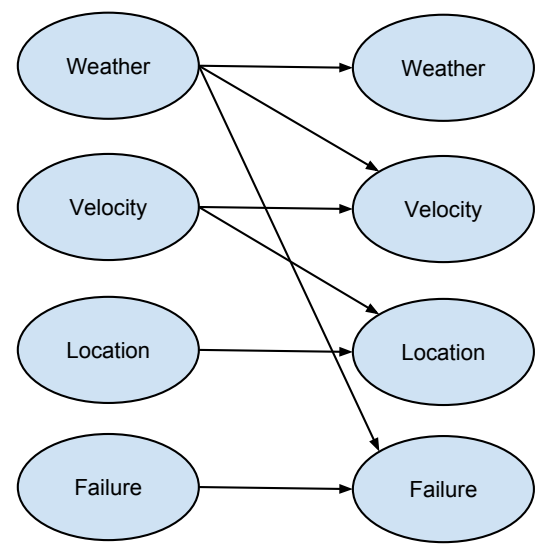

(b) $\beta \rightarrow$

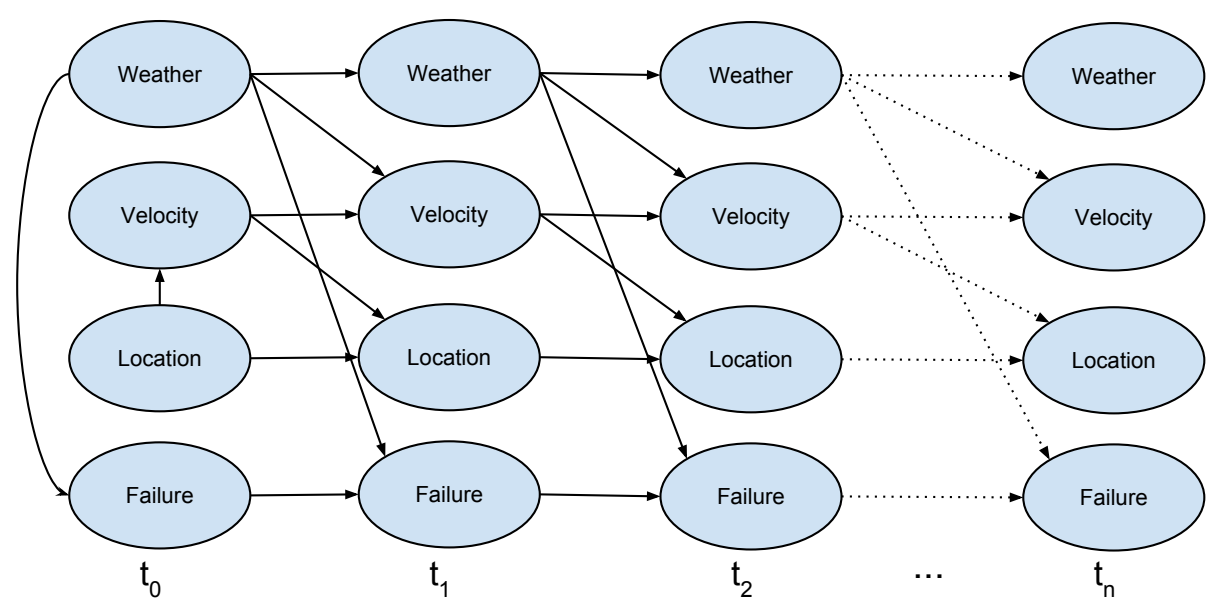

(c) $\mathrm{DBN}$

Figura 2.10 - Rede Bayesiana Dinâmica. (a) Apresenta as interações entre as variáveis em estado estacionário. (b) Apresenta as interações temporais entre as variáveis - modelo de transição. (c) Apresenta o modelo DBN completo, incluindo as interações estacionárias e temporais. Fonte: Adaptado de Koller e Friedman [52].

Este exemplo baseia-se na modelagem probabilística do comportamento de sensores existentes num carro, tal que as variáveis Weather, Velocity, Location e Failure representam, respectivamente, o Clima, o sensor de Velocidade, a Localização do carro e a possibilidade de Falha do veículo. Algumas relações merecem destaque, como por exemplo a influência da 
variável clima no sensor de velocidade $\left(\beta_{\rightarrow}\right)$, tal que a condição ambiental afeta diretamente a precisão da medição. Outras interações são mais óbvias, como a variável localização influenciando ela mesmo ou a velocidade do carro, enquanto o mesmo se encontra parado $\left(\beta_{0}\right)$.

A Figura 2.10(c), apresenta o modelo completo, composto de $\beta_{0}$ (a) e $\beta_{\rightarrow}$ (b), apresentando o caráter dinâmico do problema. De forma geral, uma DBN representa a seguinte distribuição condicional:

$$
P\left(X_{i}^{t+1} \mid X_{I}^{t}\right)=\prod_{i=1}^{N} P\left(X_{i}^{t+1} \mid \operatorname{Pa}\left(X_{i}^{t+1}\right)\right)
$$

As relações de independência representadas por esta decomposição são similares as existentes em BNs, com a única diferença de que agora são temporais.

Em se tratando de DBN é possível encontrar uma quantidade relativamente maior de trabalhos, tendo em vista que o modelo tem como base a utilização de informação temporal. Trabalhos como $[57,58]$ apresentam aplicações deste modelo para a GRN da S. cerevisiae. Assim como no caso anterior, a discussão em torno destes trabalhos gira ao redor da utilização ou criação de métodos para inferir a estrutura da GRN, na maior parte das vezes, sem nenhum conhecimento a priori sobre a estrutura. Alguns exemplos a respeito da aplicação ou desenvolvimento de métodos para inferir a estrutura da rede podem ser encontrados em [59-61].

O trabalho de Lähdesmäki et al. [62] apresenta um importante resultado teórico para a área de GRNs: a equivalência representativa existente entre os modelos de PBNs e DBNs, classificando a última como um caso particular de uma DBN, uma vez que seus estados são limitados ao caso booleano.

\subsubsection{Redes de interação Proteína-Proteína}

Uma abordagem diferente das apresentadas anteriormente, mas que faz parte da tentativa de compreensão dos fenômenos biológicos a partir de redes, são as Redes de interação Proteína-Proteína (mais conhecida em inglês como Protein-Protein Interaction PPI). A diferença deste modelo em relação aos outros reside no tipo de dado utilizado para inferir as interações, já que neste os dados mais comumente empregados são de interações físicas entre as proteínas, ao contrário do que ocorre nos outros modelos, onde as interações físicas entre os genes raramente são conhecidas, e, portanto, são estimadas de forma indireta (funcional) através de experimentos que não medem interações físicas.

Esta modelagem pode ser justificada através de dois motivos: o fato de que as interações que ocorrem entre proteínas são essenciais para a compreensão dos mecanismos celulares, e a vasta gama de dados de interações físicas ou funcionais de diversos organismos 
disponíveis publicamente. Uma importante aplicação deste modelo pode ser vista em [63], onde a rede de interação proteica da $S$. cerevisiae foi inferida através de experimentos de interação física; além da própria estrutura, o resultado mais importante consistiu em sua análise, sendo possível confirmar, através da simulação da estrutura da rede, resultados obtidos experimentalmente através da deleção de genes específicos, confirmando, através de um modelo, que este organismo é muito robusto (resistente a mutações).

Já as bases de dados que disponibilizam informações a respeito de interações proteicas podem ser divididas de três formas: primárias, que são bancos geralmente curados que fornecem dados de experimentos bioquímicos e genéticos; os secundários, que oferecem informações inferidas através de abordagens computacionais; e as bases que integram estes dados de ambas as fontes numa única plataforma, normalmente fornecendo um score associado a cada interação, representando a certeza associada a interação. Uma importante revisão sobre estas bases, os diferentes métodos existentes capazes de inferir interações e consequentemente a PPI do organismo pode ser encontrada em [7].

\subsubsection{Aprendizado da estrutura}

Engenharia Reversa no contexto de Redes Gênicas é um processo que visa estabelecer a estrutura da rede que melhor se adapte aos dados utilizados para alimentar o algoritmo, de forma automatizada e sem conhecimento a priori do processo biológico, baseandose exclusivamente em medidas tomadas de valores numéricos de expressão gênica, por exemplo. Cada modelo apresentado conta com sua própria literatura de métodos referentes a descoberta da estrutura, já que o problema de aprendizado da estrutura a partir dos dados é de amplo interesse a diversas áreas. Apesar das restrições impostas por cada modelo e a consequente peculiaridade de cada algoritmo um fator se mantém comum em todas as abordagens é a utilização de métricas baseadas em Teoria da Informação, usadas amplamente para averiguar a qualidade da topologia da rede em relação aos dados.

Os primeiros métodos para aprendizado da estrutura foram desenvolvidos para as RBo $[42,64]$, estabelecendo fundamentos que influenciaram metodologias posteriormente criadas, inclusive em outros modelos. O algoritmo [42] faz uso de medidas de teoria da informação para aprendizado de estruturas, utilizando a informação mútua para extrair relações de interação da rede, i.e., caso uma entidade detenha quantidade de "informação" suficiente a respeito de outra é estabelecido uma ligação entre as mesmas. Seguindo estes princípios, Barrera et al. [49] desenvolveram um método capaz de aprender estruturas de PGNs, fazendo uso da informação mútua levemente modificada para penalizar amostras pouco observadas. Da mesma forma, o aprendizado de BNs seguem os mesmos fundamentos, com o importante diferencial de poder incluir conhecimento a priori (através de probabilidades) para inferir as relações, um resumo destes métodos pode ser encontrado em [65]. Uma ferramenta útil para realizar o aprendizado de estruturas sob os modelos de 
BNs e DBNs é a BANJO [66].

É importante destacar que independente do modelo assumido para representar a GRN, todos os métodos requerem uma enorme quantidade de dados e recursos computacionais para realizar a inferência da topologia, e que mesmo quando há dados suficientes, não são capazes de identificar perfeitamente a estrutura da rede, principalmente se considerarmos apenas modelos direcionados, onde geralmente é impossível determinar a direção das relações, isto é, a causalidade da relação, sendo ainda um problema científico em aberto.

A área de pesquisa de aprendizado de estrutura de GRNs é extremamente ativa, existindo tanto métodos limitados aos modelos matemáticos descritos quanto a abordagens puramente baseadas em aprendizado de máquina, onde geralmente fazem uso de dados de diversas origens para inferir a rede, fundamentando-se em grande parte em técnicas de aprendizado de máquina não supervisionado e de mineração de dados, comumente não limitadas as restrições impostas pelos modelos matemáticos apresentados anteriormente, e tidos como tratamentos clássicos.

Duas abordagens puramente algorítmicas são os métodos EGRIN e EGRIN2 (do inglês Environment and Gene Regulatory Influence Network) [1,2] que para aprender a estrutura da rede consideram os níveis de mRNA, vias metabólicas existentes e associações conservadas de proteínas para identificar conjuntos de genes que são corregulados em condições específicas. A técnica de biclustering é utilizada para agrupar simultaneamente os níveis de expressão e diferentes condições experimentais (i.e., realiza o clustering de linhas e colunas de uma matriz). O modelo gerado através da aplicação deste método nos dados de H. salinarum foi capaz de predizer os níveis transcricionais de $80 \%$ dos genes do organismo.

Como este trabalho baseia-se exclusivamente em extrair arestas a partir de interações físicas fornecidas experimentalmente, evitamos revisar profundamente a vasta literatura de Redes de Regulação Gênica inferidas por expressão gênica (medida por microarray ou RNA-seq). 


\section{Estrutura da Rede}

Antes de discutir os métodos aplicados para estabelecer a nova GRN da H. salinarum, é necessário apresentar e contextualizar os dados utilizados nesta tarefa, apresentando suas etapas experimentais, a importância de serem incluídos na rede e o processamento adotado. Além disso, é importante compreender a diferença deste trabalho em relação às abordagens clássicas de construção de redes, estabelecendo interações entre os nós exclusivamente a partir da medição de associações físicas ou seus proxis.

\subsection{Descrição experimental}

A medição pareada entre os níveis de expressão gênica (correlação de Pearson, Spearman, distância Euclidiana, etc.) e a utilização de modelos de regressão (LASSO, ISTA - Iterative Soft Thresholding Algorithm, LAR - Least Angle Regression) para inferir associações entre TFs e genes, se mostraram como as abordagens mais comuns para construção de GRNs, tendo como representantes mais significativos a correlação de Pearson e a regressão LASSO, respectivamente [55]. Entretanto, ambos os métodos estão limitados a inferir redes com uma quantidade relativamente pequena de genes, não correspondendo, na maioria das vezes, ao desejo científico de transferir o conhecimento obtido destas modelagens para a compreensão global dos mecanismos de regulação. Estas limitações referem-se, respectivamente, a impossibilidade estatística de estabelecer relações causais entre os genes e a soluções múltiplas existentes na regressão, quando a quantidade de amostras é menor que a de reguladores.

Medidas sobre pares de genes, como a de Pearson, de forma geral não são capazes de inferir relações causais, nem a influência global do gene na rede, fato que se reflete na baixa qualidade das relações inferidas, já que para amostras pequenas de dados (comum na Biologia, quando se compara com a quantidade de variáveis) ruídos podem afetar significativamente a medida, uma vez que uma correlação alta não significa uma interação física. O desempenho da regressão LASSO também está sujeito a quantidade de dados, uma vez que se a abundância de amostras for menor que a de reguladores existentes, existirão múltiplas soluções, dificultando a tarefa de escolher a que tenha mais significado biológico.

Uma abordagem teórica para enfrentar a incapacidade de inferir relações causais 
exclusivamente dos dados seria a utilização do teste de causalidade de Granger. Entretanto, a quantidade de dados exigidos é, na maioria das vezes, uma limitação, já que é necessário realizar diversas medições temporais, com e sem a intervenção de interesse. Apesar desta escolha ser a mais típica para problemas que residem no domínio da Engenharia ou Computação, obter mais amostras em Biologia nem sempre é uma tarefa factível, tanto por ainda existirem limitações técnicas para medir determinados fenômenos, quanto pela necessidade de equilibrar o custo de múltiplas medições ao interesse econômico/social em um organismo. Uma alternativa tipicamente empregada na Biologia é a integração de dados heterogêneos, agrupando medições de diferentes tecnologias e condições experimentais na mesma modelagem.

O experimento de imunoprecipitação de cromatina (ChIP) é uma técnica amplamente utilizada para identificar interações entre proteínas e o DNA de uma célula in vivo, detectando a região em que uma proteína alvo interage com o DNA. A combinação do protocolo ChIP com técnicas de medição em larga escala como microarray ou sequenciamento paralelo tem se mostrado uma importante alternativa para construção de GRNs, possibilitando detectar ao longo do genoma, regiões em que há interação entre a proteína e o DNA, permitindo que relações entre os nós da rede estejam em maior concordância com o fenômeno biológico observado.

Mediante a melhor representação biológica obtida através desta abordagem e a ampla disponibilidade de dados ChIP_* em diferentes condições ambientais para o organismo de interesse, H. salinarum, este trabalho utilizará o cistromics (conjunto de todas as sequências de DNA associadas a um regulador de transcrição) deste organismo para estabelecer relações do tipo "TF regula gene", um abuso consciente e proposital de linguagem, tendo em vista as limitações da tecnologia. Desta forma, como a metodologia é essencial ao projeto, o desenvolvimento histórico e as etapas do protocolo ChIP serão descritas a seguir.

Em 1984 John T. Lis e David Gilmour criaram um método que utilizava radiação UV e um agente de crosslinking para identificar proteínas ligadas ao DNA de bactérias in vivo, mapeando, pela primeira vez, a distribuição da RNAP em genes de interesse [67]. A importância desta técnica foi tamanha que antes do fim da década já existiam outros dois protocolos aperfeiçoando a metodologia original, o XChIP e o NChIP, ambos divergindo principalmente na preparação da cromatina, necessidade que surge da diferença entre as categorias de proteínas.

O protocolo XChIP (cross-linked ChIP) tem como alvo proteínas que se ligam fracamente ao DNA (numa única fita - como TFs), tornando necessário a criação de um mecanismo de controle que permita identificar se a expressão diferencial da sequência é motivada pela ligação de um proteína ou por qualquer outro motivo. Para isso o mecanismo conhecido como ligação cruzada (mais conhecido em inglês por crosslinking) do DNA é 
utilizada, possibilitando que sequências associadas com proteínas sejam identificadas. A ligação cruzada é geralmente realizada através da adição de um formaldeído ou aplicação de radiação ultravioleta. Um problema inerente desta escolha é a impossibilidade de identificar a qual fita está associada o TF.

Já o protocolo NChIP (native ChIP) tem como alvo proteínas que se ligam fortemente ao DNA (histônicas), e portanto, não há necessidade de realizar a ligação cruzada, uma vez que a proteína está associada a ambas as fitas de DNA, sendo necessário apenas verificar se as mesmas encontram-se diferencialmente expressas ou não. Uma descrição sobre as principais vantagens e desvantagens de cada protocolo podem ser encontradas em [68], sendo útil destacar que ambas podem ser aplicadas em quaisquer proteínas, entretanto, a escolha adequada facilitará as etapas seguintes de processamento dos dados.

Como os dados de ChIP-* de H. salinarum obtidos da literatura são exclusivamente de TFs, as etapas serão descritas tendo como base o protocolo XChIP (doravante chamado simplesmente de ChIP), lembrando que a única diferença com o NChIP se encontra na primeira etapa. O protocolo ChIP pode ser descrito resumidamente através de cinco etapas: (i) cross-link através da aplicação de um formaldeído ou raios ultravioleta, fixando complexos DNA-proteína numa única fita Figura 3.1(a); (ii) aplicação de ultrassom para quebrar a fita de DNA em fragmentos de aproximadamente 500bp; (iii) adição de um anticorpo específico da proteína de interesse à solução, imunoprecipitando os fragmentos onde a mesma está ligada; (iv) purificação (remoção da proteína) dos complexos DNAproteína obtidos na ultima etapa, obtendo-se sequências de DNA que serão utilizadas para medir os níveis de ligação Figura 3.1(d); (v) amplificação dos fragmentos para posterior aplicação de métodos de medição em larga escala. Uma descrição detalhada do protocolo pode ser encontrada em [69].

Apesar das diferenças existentes entre os protocolos de imunoprecipitação, há também distintas formas de medir a quantidade de proteína presente nos fragmentos de DNA, através de chips de microarray (ChIP-on-chip) e sequenciamento paralelo de larga escala (ChIP-seq). O protocolo ChIP-on-chip pode ser visto de forma simplificada como a aplicação do método ChIP em todo o genoma. Mais especificamente, após a imunoprecipitação, a sequência de DNA associada a proteína de interesse é hibridizada, e então o nível de hibridização (que seria nível de expressão na aplicação original dos microarrays) é medido. Já o ChIP-seq diferencia-se por um única etapa do ChIP-chip, substituindo o uso de chips pelo sequenciamento paralelo de larga escala. Segundo Ho et al. [71] "a metodologia ChIP-seq geralmente produz perfis apresentando uma melhor proporção entre sinais e ruídos, o que proporciona melhores resultados quando estes sinais são processados, permitindo detectar picos mais bem definidos e consequentemente resultados mais precisos", apesar de ambas gerarem resultados finais equivalentes.

Além de incorporar dados de interação física para estabelecer relações de regulação 


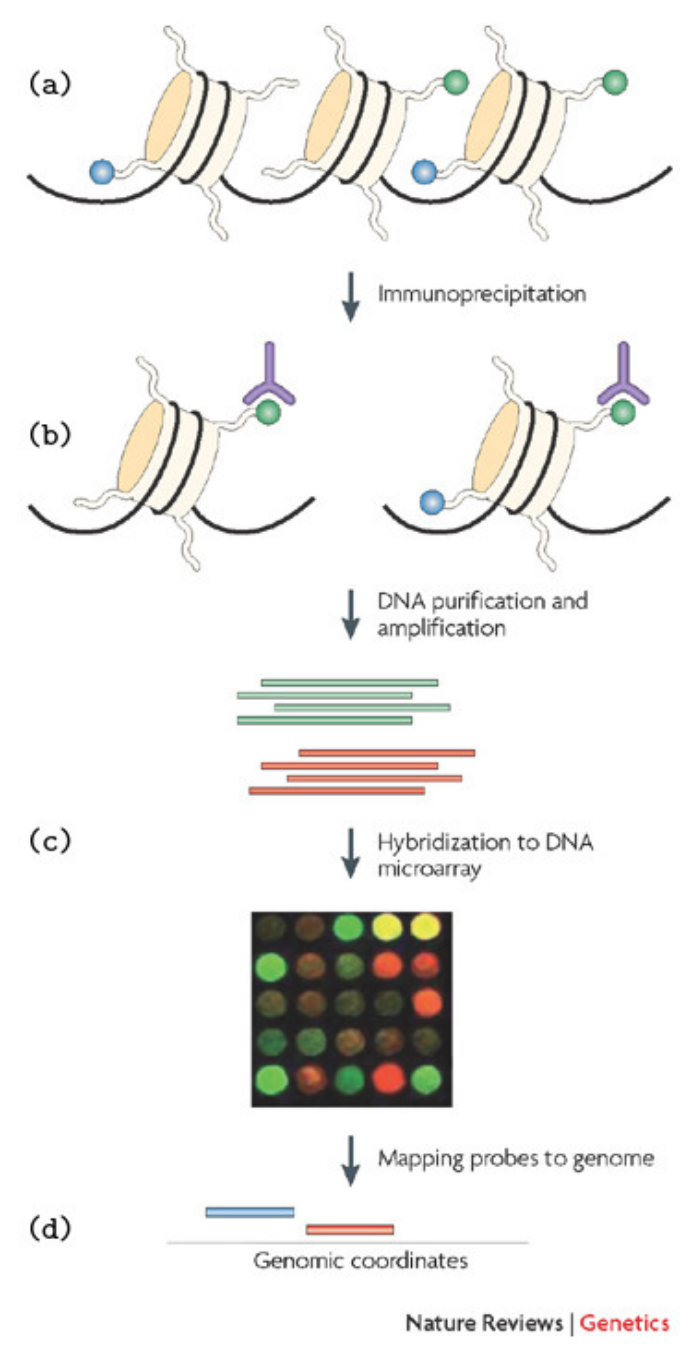

Figura 3.1 - Protocolo ChIP-on-chip. (a) Fixação dos complexos DNA-proteína através da aplicação de formaldeído. (b) Aplicação de ultrassom e imunoprecipitação através do uso de anticorpos específicos. (c) Purificação e ampliação das sequências de DNA associadas a proteína alvo, além da inserção destas sequências nos spots de microaray para hibridização. (d) Mapeamento das sondas (mais conhecido em inglês como probe) em coordenadas genômicas. Fonte: Schones e Zhao [70].

entre TFs e genes, outra novidade proposta neste trabalho é a utilização, na construção da GRN, de dados de RIP-seq e dRNA-seq para estabelecer, respectivamente, relações entre a proteína LSm e os mRNAs e entre os transcritos antisenso (asRNAs) e os mRNAs. Desta forma, a modelagem atual incluirá interações na GRN da H. salinarum até o momento, inexistentes, avançando mais um passo em direção a compreensão global dos mecanismos de controle de expressão do organismo.

Os experimentos RIP-seq e dRNA-seq são responsáveis por medir interações de RNAs com uma proteína de interesse (LSm) e detectar sítios de início de transcritos primários, respectivamente. O primeiro pode ser definido como a fusão das metodologias RNA-seq e RIP [72] (do inglês RNA Immunoprecipitation), tendo como alvo proteínas que se ligam em RNAs (mRNAs). Seu surgimento deve-se principalmente ao crescente interesse 


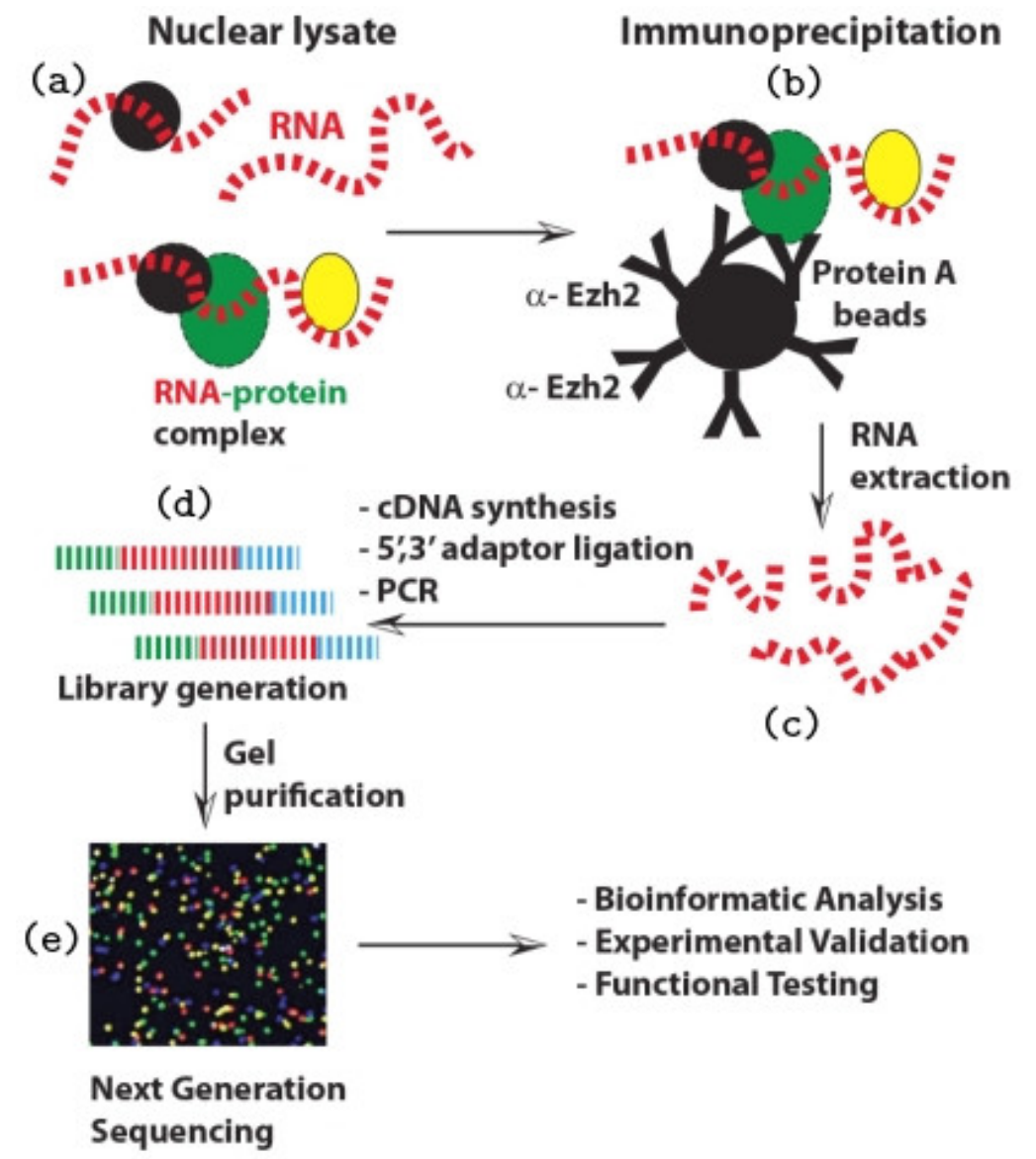

Figura 3.2 - Protocolo RIP. (a) crosslinking através de formaldeído ou raios ultravioleta. (b) aplicação de ultrassom para fragmentar a cromatina e imunoprecipitação da proteína de interesse. (c) remoção das proteínas associadas ao RNA. (d) Síntese de cDNA. (e) medição dos níveis de expressão. Fonte: Da Sacco, Baldassarre e Masotti [30].

no papel dos RNAs na regulação pós-transcricional, estando possivelmente envolvido no metabolismo de doenças como o câncer [73]. Um trabalho justificando a importância do desenvolvimento deste protocolo assim como o papel das moléculas de RNA (em especial lncRNAs) em vias metabólicas é Da Sacco, Baldassarre e Masotti [30].

Por também ser uma técnica de imunoprecipitação, as etapas do RIP-seq são em grande parte similares ao ChIP. Sua descrição pode ser feita resumidamente através das seguintes etapas: (i) aplicação de formaldeído (ou luz ultra-violeta) para fixar os complexos RNA-proteína - crosslinking; (ii) isolamento e lise do núcleo (desnecessária para a $H$. salinarum, já que a mesma não apresenta núcleo); (iii) adição de inibidores de Ribonuclease para evitar a degradação das moléculas de RNA e aplicação de ultrassom para quebrar a fita de RNA em pequenos fragmentos que conterão complexos RNA-proteína; (v) aplicação de DNase-I para degradar o DNA e posterior adição de um anticorpo para imunoprecipitar a proteína alvo; (vi) purificação do complexo (remoção da proteína) e síntese de cDNA através de transcrição reversa para sequenciamento. A Figura 3.2 ilustra as etapas descritas anteriormente, valendo observar que assim como no protocolo ChIP, a última etapa de 
sequenciamento paralelo pode ser trocada pela medição através de chips de microarray, resultando no protocolo RIP-chip.

A análise do transcritoma de um organismo através do uso de tiling array e RNA-seq forneceram importantes medições sobre os níveis de expressão dos genes e de moléculas de asRNA em diversos organismos, revolucionando a análise quantitativa e qualitativa tanto em Procariotos como Eucariotos. Além da identificação de novos transcritos, o RNA-seq permitiu a detecção e anotação em larga escala de operons (e suas exceções), fornecendo mais um nível de detalhamento na complexa tentativa de compreender de forma global os mecanismos de regulação de um organismo. Entretanto, de acordo com Wade e Grainger [74] "Estes resultados têm sido controversos e excitantes na mesma medida, já que uma grande quantidade de transcritos não canônicos têm sido encontrados no transcritoma, espalhados por todos os domínios da vida, facilmente distinguíveis, já que são não-codificantes, não limitados a regiões gênicas e frequentemente antisenso.". A identificação de transcritos em regiões não canônicas era tão surpreendente que por muito tempo estes dados foram ignorados, relegados como ruídos resultantes da própria tecnologia. Entretanto, estes ruídos começaram a ser detectados numa variedade de organismos, através de diferentes técnicas, dando origem a hipótese da transcrição pervasiva.

A hipótese da transcrição pervasiva afirma que a maioria do genoma é codificante, ao contrário do conhecimento comum de que apenas regiões codificantes eram responsáveis pela transcrição. Estes transcritos identificados ao longo do genoma foram denominados transcritos "dark matter" (a maioria massiva destes transcritos é de ncRNAs), uma referência a matéria existente no espaço, uma vez que apesar de sua existência ser detectada, ainda são desconhecidas, em geral, suas funções [75]. Entretanto, não diferente de outras hipóteses, existem trabalhos tanto a favor como contra. Os resultados contrários argumentam que os transcritos identificados não são ncRNAs e sim ruídos experimentais, consequentemente não interferindo na regulação gênica [76,77]. Já os favoráveis refutam complemente a possibilidade de ser ruído, afirmando que as medidas que confirmam a hipótese surgiram de diferentes técnicas, e não de uma única, realizadas também em vários organismos, o que dá suporte a hipótese da transcrição pervasiva [75].

Tendo em vista o provável papel dos ncRNA na regulação gênica, era necessário desenvolver um método capaz de detectar claramente estes RNAs de interesse, separandoos de eventuais produtos de degradação/processamento. Neste contexto, o dRNA-seq (differential RNA-seq) foi desenvolvido com a função de distinguir transcritos primários de processados, diferenciando RNAs que apresentam um grupo trifosfato na região 5' como primários e os que detêm um único grupo monofosfato como processados. O trabalho de Sharma et al. [78] é um exemplo bem-sucedido da aplicação desta técnica para mapear globalmente sítios de início de transcrição (mais conhecido em inglês como transcription start site - TSS), sendo uma importante abordagem para melhor caracterizar a transcrição 
pervasiva, permitindo o mapeamento global dos TSSs por todo o genoma do organismo. A identificação dos TSSs é feita através da comparação entre os sequenciamentos de uma biblioteca enriquecida com transcritos primários ("+") e uma controle ("-"), onde uma posição é dita ser um TSS caso exista uma maior contagem na biblioteca enriquecida.

É possível classificar um TSS através da análise de sua posição relativa a um gene, sendo as seguintes classificações mais comumente aplicadas: TSSs primários (pTSSs) como aqueles localizados upstream a uma região anotada; TSSs internos (iTSSs) como aqueles internos a um gene; e TSSs antisenso (aTSSs) como aqueles antisenso a regiões codificantes. Uma classe que receberá atenção deste trabalho é a de aTSSs, uma vez que estas posições podem estar associadas a produção de pequenas moléculas de RNA não codificante (asRNAs). Os asRNAs constituem uma classe de moléculas que foi negligenciada por cerca de trinta anos, pois, acreditava-se que, de modo geral, sua atuação era limitada a poucos genes, fato refutado apenas recentemente, graças a ampla disponibilidade de transcritoma. Mais especificamente, a regulação através de asRNAs ocorre após a transcrição, onde o asRNA produzido se ligará a uma parte ou a todo o mRNA transcrito na fita oposta, impedindo que a "mensagem" produzida seja traduzida em proteína.

Segundo Georg e Hess [6], a análise sistemática da expressão antisenso foi ignorada por tanto tempo por três razões: falta de algoritmos capazes de predizer a existência de asRNAs; crença de que as medições de asRNA nos experimentos de microarray eram artefatos gerados durante a síntese de cDNA; e a interpretação errônea dos resultados. As duas primeiras eram limitações técnicas existentes à época, e recentemente superadas. Entretanto, a terceira, só começou a ser atacada recentemente, com o aumento significativo de trabalhos baseados em múltiplas técnicas de medição, aprofundando cada vez mais e fornecendo maiores evidências do papel destas moléculas.

Com a ampla disponibilidade de resultados existentes na literatura confirmando o papel dos asRNAs e da transcrição pervasiva, é útil avaliar o papel destas moléculas no organismo de interesse do trabalho. A maneira mais simples de visualizar estes dados é através de um browser genômico, representando os níveis de expressão através de cores. A ferramenta Gaggle Genome Browser (GGB) [79] permite este tipo de visualização, integrando dados de diferentes origens experimentais numa plataforma única de representação. A Figura 3.3 apresenta uma visualização obtida através da ferramenta. Os retângulos representam genes, amarelo para os da fita forward e laranja para a reverse; os triângulos em rosa, as posições resultantes do experimento ChIP-*; os triângulos em azul, os TSSs detectados; o heatmap das cores verde e vermelha representam a intensidade dos níveis de expressão, verde para os genes com log ratio negativo e vermelho para positivo.

O eixo horizontal de medições representa as diferentes sondas ao longo do genoma, enquanto o vertical as medições temporais, destacando que a visualização exibe distintos experimentos, com o heatmap acima do gene representando medições da fita forward e 


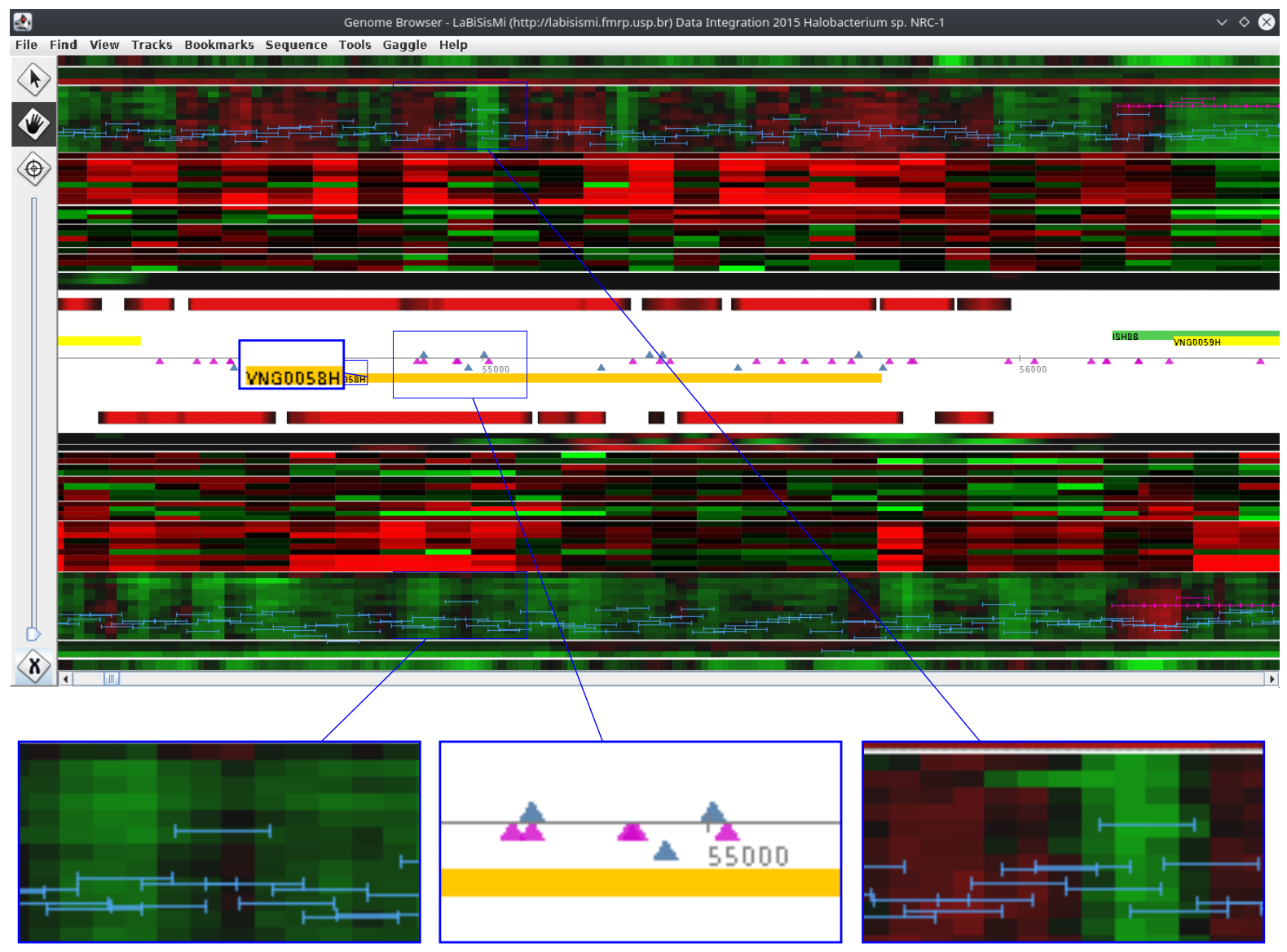

Figura 3.3 - Exemplo de visualização com dados de H. salinarum na ferramenta GGB. Os retângulos abaixo da imagem principal apresentam o possível papel dos aTSSs na regulação gênica. O retângulo localizado à esquerda apresenta os níveis de expressão na fita reverse; ao meio, o retângulo que apresenta a região interna ao gene "VNG0058H" onde existem dois aTSSs; a direita é apresentado a mesma região na fita forward.

abaixo, da fita reverse. Uma descrição detalhada destes experimentos será realizada na seção 4.2 .

\subsection{Obtenção dos dados}

As medições referentes aos experimentos ChIP_* foram coletadas e unificadas exclusivamente da literatura, diferente dos de RIP-seq e dRNA-seq, fornecidos através da colaboração com o grupo de pesquisa LaBiSisMi (Laboratório de Biologia Sistêmica de Microrganismos), sediado na Faculdade de Medicina de Ribeirão Preto (FMRP) e coordenado pela Profa. Tie Koide.

Os dados de ChIP-chip empregados neste trabalho podem ser divididos em dois grupos, considerando o tipo de TF medido. O primeiro corresponde aos TFs básicos, contando com as seguintes medições: todos os TFBS (tfbA, tfbB, tfbC, tfbD, tfbE, tfbF, 
e tfbG), um TBP (tbpB) e três TRs (Trh3, Trh4, e VNG1451C), medidos na condição experimental $\mathrm{DO}=0,5,37^{\circ} \mathrm{C}$, doravamente considerada referência [80].

O segundo grupo refere-se ao dos TFs específicos, cujas medições são as seguintes: RosR na condição ambiental estresse oxidativo (presença de $\mathrm{H}_{2} \mathrm{O}_{2}$ ), frequente em seu habitat [81]; Idr1 e Idr2, que sob baixa quantidade de ferro interagem de forma complementar, ajudando a manter a homeostase do metal [82]; AsnC, VNG1179C, VNG1237C, Trh[2, $3,4,6,7]$ no estado superexpressão de Feast/Famine (abundância/carência nutricional), que são fatores de transcrição envolvidos na identificação da concentração de aminoácidos existentes no organismo [83].

Ao contrário dos dados de ChIP-chip que apresentam diversas fontes, os de ChIPseq foram obtidos de um único trabalho. As medições realizadas em [84] são referentes aos seguintes TFs: tfbB, tfbG, tfbD, colhidos sobre a condição experimental referência. Segundo Seitzer et al. [84] a medição destes TFs foi realizada novamente devido à necessidade de obter posições mais precisas para identificação de motifs comuns entre os três TFs. A Tabela 2 apresenta de forma compilada todos os experimentos, suas condições e respectivas referências.

\begin{tabular}{ccccc}
\hline Proteínas & Tipo & Condição & GEO & Referência \\
\hline tfb[A-G], tbpB e TRs & ChIP-chip & Condição referência & GSE7045 & Koide et al. [80] \\
AsnC, VNG1179C, VNG1237C, & & & & \\
Trh[2, 3, 4, 6, 7] & ChIP-chip & Feast/Famine & GSE62051 & Plaisier et al. [83] \\
RosR & ChIP-chip & $\mathrm{H}_{2} \mathrm{O}_{2}$ & GSE33980 & Sharma et al. [81] \\
Idr1 e Idr2 & ChIP-chip & Quantidade de ferro & GSE29705 & Schmid et al. [82] \\
tfbB, tfbG, tfbD & ChIP-seq & Condição referência & - & Seitzer et al. [84] \\
\hline
\end{tabular}

Tabela 2 - Dados de ChIP-chip e ChIP-seq para Halobacterium salinarum NRC-1.

O trabalho de Zaramela [5] foi responsável por estabelecer o protocolo RIP-seq para o organismo H. salinarum. As etapas executadas para obtenção dos dados utilizados no trabalho foram as seguintes: (i) Cultivo das linhagens de H. salinarum NRC1-cmyc (superexpressando cauda cmyc) e LSm-cmyc (superexpressando VNG1496G, gene codificante da LSm) até densidade ótica de 0.75; (ii) após transferir as suspensões celulares para placas de Petri, as mesmas foram irradiadas com luz UV no Crosslinker GE Healthcare UV $800 x 100 \mu \mathrm{J} / \mathrm{cm}^{2}$; (iii) aplicação de solução lise, inibidor de proteínase e RNAse (OUT Invitrogen $2 \mu L / 10 m L$ ), o primeiro para degradar o núcleo (desnecessário na $H$. salinarum), o segundo e terceiro, para impedir a degradação das proteínas e dos RNAs, respectivamente; (iv) aplicação do anticorpo anti-cmyc (Sigma - M4439); (v) isolamento do RNA imunoprecipitado, aplicando $15 \mu L$ de Proteinase K (Fermentadas); (vi) finalmente, a purificação do RNA foi realizada por extração orgânica ou utilizando o kit MinElute Reaction Cleanup - Qiagen. 
As bibliotecas foram construídas seguindo o procedimento padrão, com a criação de um total de quatro bibliotecas, duas para cada uma das fitas, através do kit TruSeq Stranded mRNA. Para quantificar as bibliotecas e analisar o tamanho dos fragmentos gerados, os kits KAPA SYBR FAST Universal qPCR e Agilent High Sensitivity DNA foram, respectivamente, utilizados. A quantificação e análise dos fragmentos é de suma importância para o posterior sequenciamento, tendo em vista a necessidade de garantir uma quantidade balanceada de reads oriundos de cada amostra. O sequenciamento simultâneo das quatro bibliotecas gerou um total de 12 milhões de reads com qualidade phred $>30$, todos foram aparados e alinhados utilizando as ferramentas FASTX-Toolkit e Bowtie $(\mathrm{m}=1,50$ ciclos $)$, respectivamente. Maiores detalhes a respeito das etapas experimentais e de processamento podem ser encontrados em [5].

Finalmente, as medidas de dRNA-seq foram obtidas através do trabalho de Caten [85], responsável por identificar TSSs, seguindo as seguintes etapas: Para extraí-los o kit mirVana miRNA (micro RNA) Isolation (Ambion) foi utilizado em réplicas de um único pellet, através do protocolo de extração de RNA total, gerando amostras quantificadas através de um espectrofotômetro; para garantir que não existissem contaminações, as amostras foram tratadas com Turbo ${ }^{\mathrm{TM}}$ DNase Ambion ${ }^{\circledR}$, eliminando qualquer DNA genômico ou plasmídico; em seguida, reações PCR foram utilizadas para confirmar a não existência de contaminação, utilizando como controle positivo o DNA genômico da $H$. salinarum. As etapas previamente descritas são a base para qualquer procedimento de extração de RNA, entretanto, como o objetivo deste experimento é diferenciar RNAs processados de primários, mais uma etapa é necessária, a aplicação da enzima TEX+.

Com a amostra de RNA livre de qualquer contaminação é necessário dividi-la em duas parte para identificar os transcritos. A primeira é tratada com a enzima TEX+ (Terminator 5'-Phosphate-Dependent Exonuclease) enquanto a segunda com tampão TEX, servindo de controle para as próximas etapas. Para garantir que houve a depleção de RNAS processados (rRNAs) ambas as partes foram comparadas através de eletroforese. A quantificação das bibliotecas foi realizada com o kit Quant-iT RiboGreen RNA Assay (Invitrogen), que por se tratar de uma marcação fluorescente específica para RNA minimiza a interferência por nucleotídeos livres ou contaminantes como proteínas, fornecendo uma quantificação mais precisa.

Para garantir que o sequenciamento mantivesse proporções iguais entre as duas bibliotecas, foi realizada uma quantificação através de qPCR com o kit KAPA Library Quant (Kapa Biosystems), que através do uso de adaptadores ligados nas moléculas permite a quantificação exata de moléculas para sequenciamento, possibilitando o ajuste dos volumes; finalmente, o sequenciamento das bibliotecas foi feito através do kit MiSeq Reagent v2 300 cycles Paired-end (Illumina) no sequenciador MiSeq. Os reads então obtidos passaram por uma pipeline clássica de processamento, sendo realizado primeiro a remoção 
dos adaptadores utilizados na etapa anterior através da ferramenta FASTX-Toolkit e posterior alinhamento ao genoma referência de H. salinarum através do software Bowtie, desconsiderando qualquer read que se alinhasse em mais de uma posição. Maiores detalhes sobre cada uma das etapas descritas acima podem ser encontrados em Caten [85].

Relações do tipo Proteína-Proteína podem ser obtidas a partir de uma série de bancos de dados primários, que de forma geral disponibilizam dados de interação obtidos através de experimentos bioquímicos. Uma alternativa às bases primárias são as secundárias, cuja principal característica é a mineração de dados nas bases primárias para posterior aplicação de modelos matemáticos responsáveis pela predição de scores de qualidade de interações não observadas experimentalmente.

A base STRING [7] é um exemplo bem conhecido deste grupo, aplicando um modelo computacional sob os seguintes dados: interações experimentais extraídas de bases primárias; informação sobre vias metabólicas de bases de dados curadas; mineração de dados em artigos para descobrir possíveis relações; e predição algorítmica. Cada uma destas fontes é então combinada, associando uma probabilidade a interação proteica predita; uma revisão de outros métodos que têm como princípio predizer interações através da combinação de dados pode ser encontrada em [7].

A interface intuitiva e o amplo uso desta ferramenta pela comunidade foram atributos essenciais para sua escolha como fonte de dados deste trabalho. Os dados obtidos correspondem a 322.926 interações entre pares de proteínas existentes na H. salinarum, cada um associado a um conjunto de probabilidades que foram preditas para os diferentes grupos de dados utilizados. Ressalta-se que, como será explicado em seguida, utilizouse neste trabalho somente o subconjunto de informações referentes a experimentos de interação, ignorando predições e inferências indiretas.

\subsection{Pré-processamento}

Grande parte das ferramentas descritas nesta seção basearam-se em métodos responsáveis pela deteç̧ão de picos, uma vez que o resultado da maioria deles geraram sinais (mais conhecido na área de sequenciamento como perfil - Figura 3.4). Este sinal nada mais é do que uma representação visual da quantidade de sequências alinhadas a regiões específicas do genoma referência (ou intensidade média de expressão), permitindo a aplicação da teoria de Processamento e Análise de Sinais para identificação de regiões de interesse, que neste contexto são representadas por áreas onde há um crescimento repentino do sinal, problema amplamente conhecido na área de sinais como detecção de picos.

A identificação de sítios de ligação através dos dados de ChIP-chip foi obtida por Reiss, Facciotti e Baliga [86]. O procedimento se baseia numa deconvolução do perfil 
- Cell lysis

- Sonication/shearing of DNA

- Isolate protein-DNA complex
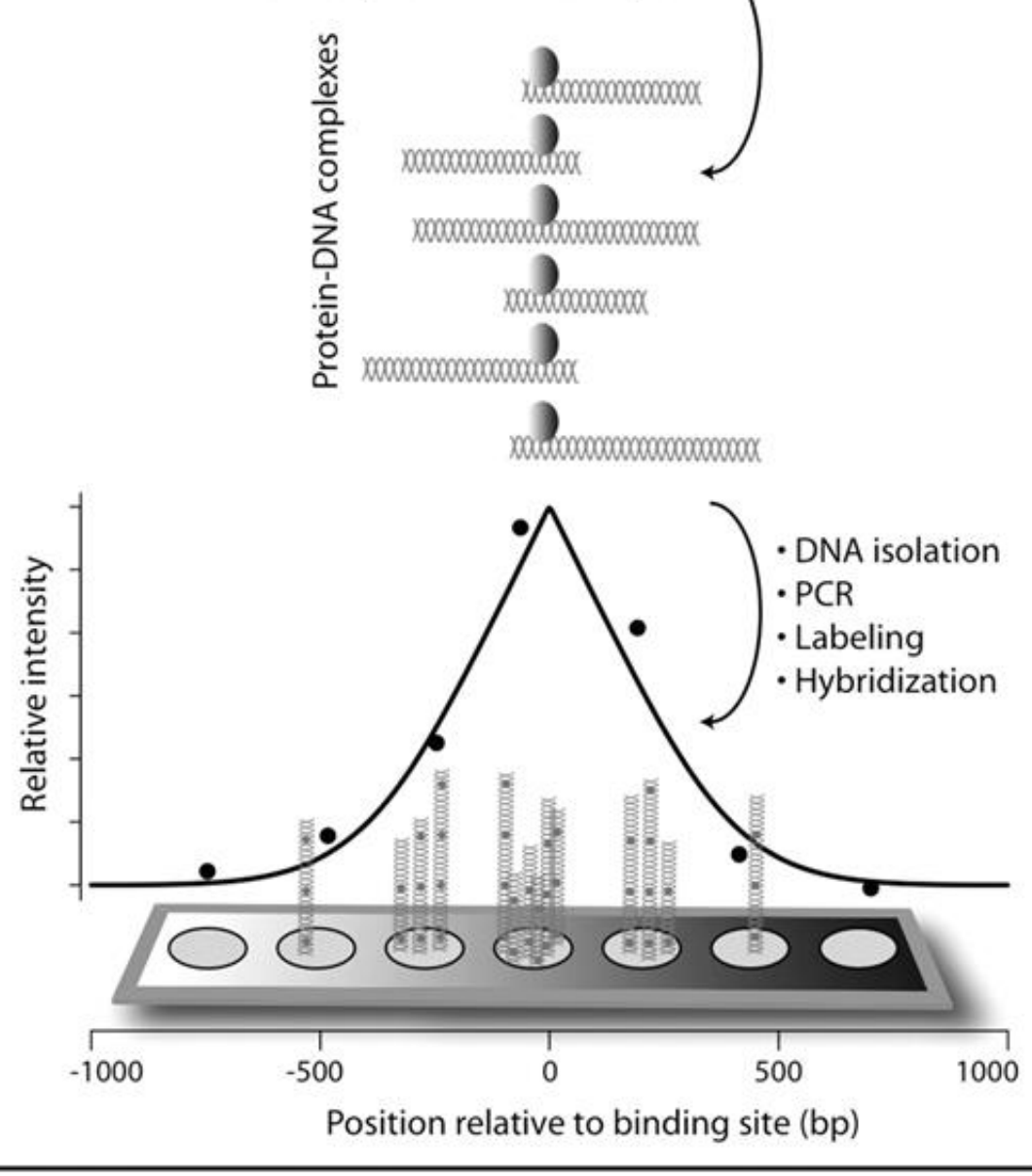

Figura 3.4 - Perfil de sinal. A parte superior apresenta as etapas de um experimento ChIP-chip, que tem como resultado complexos DNA-proteína. Após a purificação destes complexos ocorre a medição dos níveis de expressão gênica, resultando num sinal que corresponde ao nível de intensidade de cada fragmento de DNA. Fonte: Adaptado de Reiss, Facciotti e Baliga [86].

ChIP-chip, buscando realizar a regressão do sinal através de uma função "perfil de pico". Este mesmo trabalho também demonstrou que este algoritmo pode aumentar a efetividade na detecção de sítios de ligação em até cinco vezes, se comparado com as técnicas existentes à época. Os p-valores resultantes da aplicação do procedimento foram transformados em estimativas LFDR (do inglês local false discovery rate), e em seguida um limiar foi utilizado para filtrar apenas os valores relevantes, resultando em 17.343 posições (Start, End), já que a localização exata do sítio de ligação está sujeita a imprecisões inerentes da tecnologia.

De acordo com Amman et al. [87] um problema inerente a análise de dados de dRNA-seq era em grande parte devido à detecção manual entre os sinais verdadeiros e ruídos acidentais provocados pela degradação incompleta de transcritos processados. O procedimento para anotação manual consiste em mapear os reads de cada biblioteca ao genoma referência através da inspeção visual auxiliada por um browser genômico, tornando-o altamente repetitivo e sujeito a erros, além de comprometer a reprodução dos 
resultados graças a subjetividade da tarefa.

Com a evidente necessidade de utilizar uma ferramenta para automatizar o procedimento, o método TSSAR [87] (TSS Annotation Regime) foi escolhido para a tarefa. A ferramenta se baseia em um modelo estatístico para a diferença entre as bibliotecas $[+]$ (enriquecida com TSS primários) e [-], assumindo uma distribuição de Poisson Inflada de Zeros (mais conhecida por em inglês por ZIP) [88] para cada uma delas e consequentemente uma distribuição Skellam para a diferença. Assim como seria feito numa inspeção visual, a região é classificada como um TSS primário caso exista um pico mais pronunciado na biblioteca $[+]$, comparado com a [-]. Existem três principais parâmetros de entrada para a ferramenta. Esta análise foi realizada pelo Dr. Felipe ten Caten do LaBiSisMi [85]. O primeiro é o p-valor, que determinará a "confiança" com que aceitaremos o ponto avaliado, neste caso p-valor $=0,001$. O segundo parâmetro é um limiar para garantir a eliminação de ruídos, cujo valor foi de 10 reads por posição. Já o último parâmetro refere-se a uma janela de agrupamento de TSSs, neste caso, pontos que estivessem a uma distância de 10pb eram agrupados num único. A ferramenta está disponível em $<$ http://www.nibiru.tbi.univie.ac.at/TSSAR/>.

Para identificar regiões enriquecidas do experimento RIP-seq uma abordagem de segmentação de sinais foi utilizada. O perfil de contagem da biblioteca LSm-cmyc foi analisado e segmentado para todo o genoma. A segmentação do perfil seguiu a abordagem padrão sob o prisma de segmentação de sinais, adotando um critério que consistia na separação de regiões que não apresentavam reads das que continham ao menos um read mapeado. Entretanto, este critério sozinho não é suficiente para segmentar regiões contínuas, uma vez que o sinal é discreto, e, portanto, segmentos distintos e separados por até 10pb foram agrupados num único.

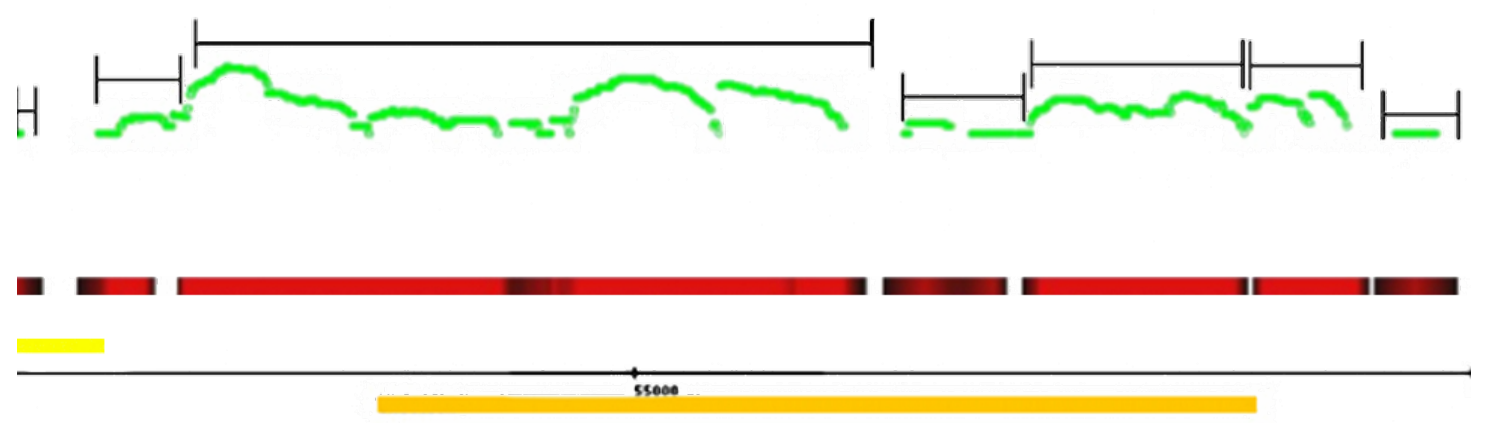

Figura 3.5 - Segmentos de sinal obtidos no processamento RIP-seq. Os pontos em verde representam os dados de RIP-seq ainda não normalizados. Os retângulos em vermelho, amarelo e laranja, representam os dados normalizados, os genes da fita forward e os da fita reverse, respectivamente.

A segmentação do perfil gerou um total de 1.760 segmentos (iguais aos da Fi- 
gura 3.5), 1.234 no cromossomo (599 forward e 635 reverse), 98 no plasmídeo pNRC100 (53 fwd. e 45 rev.) e 429 no plasmídeo pNRC200 (212 fwd. e 217 rev.). Para classificá-los como enriquecidos ou não, a razão entre os valores de abundância dos segmentos (obtidos do perfil de contagem das bibliotecas) foram comparados com o da biblioteca de controle negativo, descartando todos os segmentos com $\log _{2}($ ratio $) \leq 0$. Este critério resultou em 1.060 segmentos considerados enriquecidos, distribuídos da seguinte forma: 779 no cromossomo (376 fwd. e 403 rev.); 41 no plasmídeo pNRC100 (23 fwd. e 18 rev.); 240 no plasmídeo pNRC200 (118 fwd. e 122 rev.). Esta análise foi realizada pela Dra. Lívia Zaramela do LaBiSisMi [89].

O último dado que necessita ser processado refere-se as interações proteicas. Como a hipótese subjacente a modelagem baseia-se exclusivamente no uso de dados de interações físicas, é mandatório filtrar este conjunto de dados visando a eliminação daqueles que não se enquadram neste critério. Uma vantagem de utilizar dados da base STRING é a forma com que os mesmos são disponibilizados, pois, apesar de combinar diferentes dados num único valor, as probabilidades associadas a cada um deles são fornecidas separadamente. Desta forma, o pré-processamento consiste na eliminação de todas as interações cujos valores de probabilidade preditos através de dados experimentais forem menores que 0,85 . Este cutoff escolhido resultou em 3.602 interações, obtidas de um total de 322.926.

\subsection{Estrutura da rede}

Para que fosse possível alcançar o objetivo científico proposto por este trabalho, um conjunto de ferramentas computacionais capazes de processar, integrar e analisar dados de diferentes origens experimentais foi desenvolvido. Todo o ferramental necessário foi implementado na linguagem Python, facilitando extensões futuras uma vez que a mesma é amplamente utilizada na Bioinformática.

A modelagem proposta assumirá que a GRN da $H$. salinarum pode ser representada através de um DAG, o que até certo ponto limita o poder de representação do fenômeno biológico (como relações de feedback), entretanto, a complexidade do fenômeno físico obriga que a modelagem seja simplificada para reduzir os recursos computacionais empregados assim como facilitar sua interpretação. Desta forma, todas as arestas desta GRN podem ser interpretadas como potenciais relações de causa e efeito, estabelecidas a partir de experimentos físicos, e não aprendidas através de medições de expressão gênica.

Apesar da modelagem proposta não considerar uma variedade de elementos atuantes na regulação (ainda não descobertos ou medidos), extrair conhecimento biológico através da visualização da estrutura resultante não se mostrou uma tarefa fácil devido ao grande número de relações e elementos existentes na rede. Em vista desta limitação, este trabalho produziu como subproduto um script para facilitar a navegação de um usuário por esta 
rede. A ferramenta é utilizada através da linha de comando, e a interação se dará pela simples inserção do nome de um nó existente na rede, resultando na imagem de um grafo que detém todos os elementos que se relacionam com o nó de interesse. Esta simples ferramenta foi também implementada em Python, fazendo uso direto do pacote pygraphviz.

Os dados resultantes do pré-processamento por si só não fornecem nenhuma informação a respeito da interação com outras entidades, sendo necessário adotar "regras" específicas a cada um dos experimentos para estabelecer ou não a interação entre os elementos da rede. O termo processamento será aplicado para representar o conjunto de regras definidas para o experimento. Os resultados de cada regra serão apresentados de forma construtiva, cada uma delas estendendo os resultados obtidos na anterior, tendo a seguinte ordem de apresentação:

1. Processamento de dados ChIP-*;

2. Processamento de dados dRNA-seq;

3. Processamento de dados RIP-seq;

4. Processamento de dados Proteína-Proteína.

Como os dados ChIP-* fornecem medições de quais regiões de DNA interagem com proteínas de interesse, os mesmos serão utilizados para estabelecer interações entre os TFs (única categoria medida) e os genes do organismo. De fato, a quantidade de medições destes experimentos são tão abundantes que representarão a maior fonte de informação sobre a estrutura. Os dados de entrada nesta etapa já foram pré-processados [2,86], resultando num conjunto de pontos em que se acredita existir interação entre o DNA e o TF alvo, existindo para cada um destes uma medida de erro associada, inerente tanto ao experimento quanto ao algoritmo de pré-processamento.

Estes pontos são representados através de triângulos rosas na Figura 3.6, onde a linha hachurada ligada ao mesmo representa o erro (ou incerteza) associado a medição. Nos experimentos de ChIP-chip e ChIP-seq estes erros são de, respectivamente, 50 e 25 pbs (representado por $\alpha$ ), tal que o triângulo está localizado no ponto médio da região de erro. Portanto, como todas as medições estão associadas a uma região, a maneira mais simples de estabelecer interações entre os TFs e os genes é através de um critério de distância, i.e., será dito que um TF está interagindo (e eventualmente regulando) com um gene caso este esteja a uma distância aceitável da região codificante, sendo uma tentativa de representar o fenômeno biológico de interação física entre a proteína e a região promotora do gene.

Os parâmetros $\delta e \epsilon$ foram estabelecidos para controlar a distância (em pares de base) com que um TF será incluído ou não como controlador do gene, representando respectivamente, a distância aceitável antes e após o início do gene, resultando num 
intervalo de aceitação da forma $\left[\mathrm{Gene}_{\text {start }}-(\delta+\alpha)\right.$, Gene $\left._{\text {start }}+(\epsilon+\alpha)\right]$ no sentido upstream e $\left[\right.$ Gene $_{\text {start }}-(\epsilon+\alpha)$, Gene $\left._{\text {start }}+(\delta+\alpha)\right]$ downstream. Portanto, estabeleceu-se que o TF está controlando upstream o gene quando sua posição final é maior ou igual ao ponto Start $-\delta$ e sua posição inicial menor ou igual a Start $+\epsilon$, intervalo representado de forma visual através das linhas verticais vermelhas na Figura 3.6(a). Na fita reversa, a relação complementar é usada, ou seja, um TF é dito controlador do gene caso sua posição final seja menor ou igual a Start $+\delta$ e maior ou igual a Start $-\epsilon$, intervalo representado novamente através de linhas vermelhas na figura Figura 3.6(b).

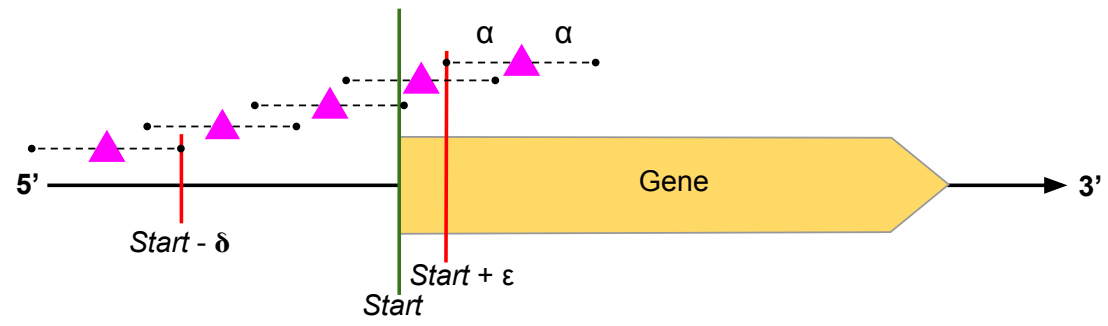

(a) Critério forward

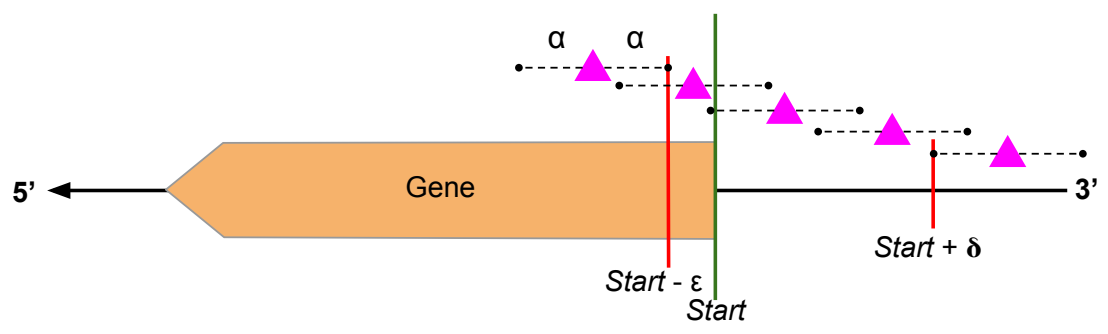

(b) Critério reverse

Figura 3.6 - Critério utilizado para estabelecer interações entre TFs e genes utilizando dados de ChIP-chip e ChIP-seq. (a) Critério de controle na fita forward, todos os TFs cujas posições finais e iniciais pertençam ao intervalo $[$ start $-\delta$, start $+\epsilon]$ terão relações estabelecidas com o gene. (b) Critério de controle na fita reverse, todos os TFs cujas posições finais e iniciais pertençam ao intervalo $[$ start $-\epsilon$, start $+\delta]$ terão relações estabelecidas com o gene.

A escolha de uma região anterior ao início do gene é necessária já que a verdadeira localização da região promotora não é conhecida para a maioria esmagadora dos genes. Num primeiro momento, aceitar um TF que está localizado após o início do gene pode não fazer sentido, entretanto, é importante manter este critério pela simples possibilidade de existirem erros nas anotações dos genes, de tal forma a ser possível que a verdadeira região promotora do gene esteja localizada dentro de si mesmo, seguindo a anotação (potencialmente errônea) atual.

A Figura 3.7 apresenta o resultado desta primeira etapa de processamento para o gene de interesse VNG0637G (NADH dehydrogenase/oxidoreductase; 562 aminoácidos), contendo nós que buscam representar as diferentes etapas do fenômeno de regulação gênica: 
os que têm nomes iniciados por "VNG" representam os genes do organismo; os ancestrais diretos dos últimos são os TFs, específicos e gerais, cujos nomes são iguais aos apresentados na seção 3.2; os nós com prefixo "rna" e "prot" representam o produto da transcrição do gene e da tradução do RNA, respectivamente.

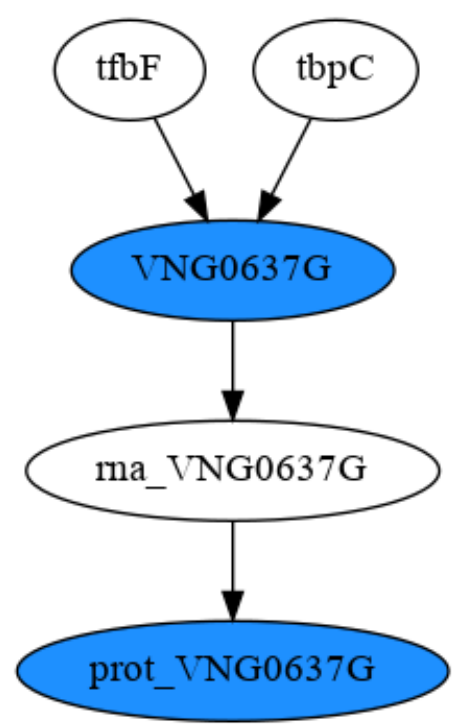

Figura 3.7 - Rede contendo interações dos experimentos ChIP_* para o gene VNG0637G. Os nós tfbF e tbpC representam os reguladores identificados pelo critério, enquanto os nós com prefixo "rna" e "prot" representam, o mRNA transcrito e a proteína resultante da tradução, respectivamente.

É importante ressaltar que o resultado parcial apresentado pela Figura 3.7 é apenas um exemplo escolhido para ilustrar as relações extraídas dos dados ChIP_*, "TF controla gene", obtendo-as para todos os nós que representam genes na rede. Vale também lembrar que estas arestas são uma tentativa de representar o fenômeno físico de controle da regulação gênica exercido por um TF, sendo o principal fator que norteou a escolha dos parâmetros adotados pela regra. Os parâmetros escolhidos foram: $\delta=0$ e $\epsilon=0$, instituindo como reguladores pontos ChIP cujo início encontrava-se a $[-100,+100]$ pbs em relação ao início do gene para medições ChIP-chip e $[-50,+50]$ pbs para ChIP-seq.

Tendo representado o mecanismo mais essencial de controle (pré-transcricional), é oportuno adicionar mais complexidade a modelagem proposta, incluindo agora um dos vários mecanismos de controle pós-transcricional, a interação dos asRNAs com os RNAs transcritos pelos genes na fita oposta. A informação para estabelecer as arestas representando este fenômeno físico será obtida através dos dados pré-processados de dRNA-seq, que representam posições onde possivelmente existem TSSs.

A Figura 3.8 ilustra as posições das já descritas três possíveis maneiras de classificação dos TSSs: pTSSs, iTSSs e aTSSs. A classificação de interesse para este trabalho, e que constituiu uma das novidades propostas por esta dissertação, é a utilização dos TSSs classificados como antisenso (aTSSs) como reguladores dos níveis de transcrição. De fato, 
a hipótese subjacente a esta interação é que todos os aTSS transcrevem um asRNA que pareará com seu complementar, o que não é necessariamente verdade sempre. Uma ressalva importante é que não houve validação experimental desta hipótese então trata-se aqui de algo que deve ser entendido como "potencial", e não como "medição". Esta interação é um dos vários mecanismos existentes de regulação pós-transcricional, e ocorre especificamente através do pareamento do asRNA com o RNA transcrito pela fita oposta, impedindo que o último seja traduzido numa proteína. Existem trabalhos fornecendo evidências para a confirmação deste mecanismo [6,31], que recentemente voltou a receber atenção devido à hipótese da transcrição pervasiva - Figura 3.3.

É importante destacar que não há necessidade alguma do asRNA ter o mesmo tamanho do RNA da fita oposta para interferir na tradução do mesmo. De fato, um organismo será muito mais eficiente do ponto de vista energético se o mesmo for capaz de "atrapalhar" a tradução do RNA ligando um pequeno asRNA, o que será suficiente para que a tradução deste complexo seja impedida ou gere uma proteína truncada.

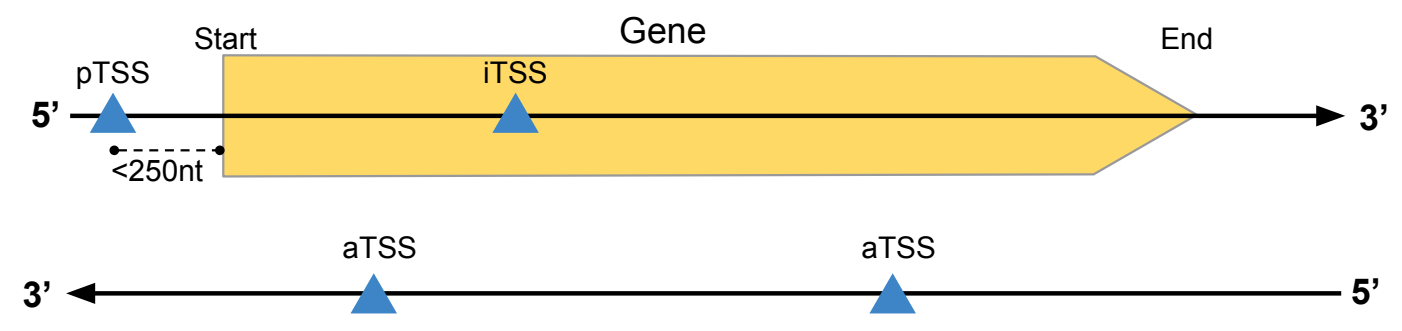

Figura 3.8 - Critério utilizado para estabelecer interações entre aTSSs e RNAs através do dRNA-seq.

Desta forma, as arestas entre aTSSs (asRNAs) e os RNAs produzidos pelos respectivos genes serão estabelecidas caso exista algum aTSS para o gene, ou seja, quando um aTSS estiver antisenso e limitado à região gênica anotada, então será dito que o mesmo interage com o mRNA deste gene, lembrando que esta afirmativa é um abuso de linguagem proposital, mas verossímil, tendo em vista as simplificações admitidas para estabelecer estas relações.

O grafo apresentado na Figura 3.9 além de conter interações que representam o controle pós-transcricional dos asRNAs também é uma extensão do grafo anterior, contendo tanto interações dos dados ChIP-* quanto de dRNA-seq. Os nós que tem como prefixo "TSS" representam os asRNAs transcritos pelas posições identificadas no dRNA-seq. Da mesma forma que os RNAs convencionais possuem reguladores para controlar seus níveis de transcrição, o mesmo é válido para os asRNAs, e, portanto, o critério adotado para estabelecer interações será igual ao estabelecido para o experimento ChIP-*. 


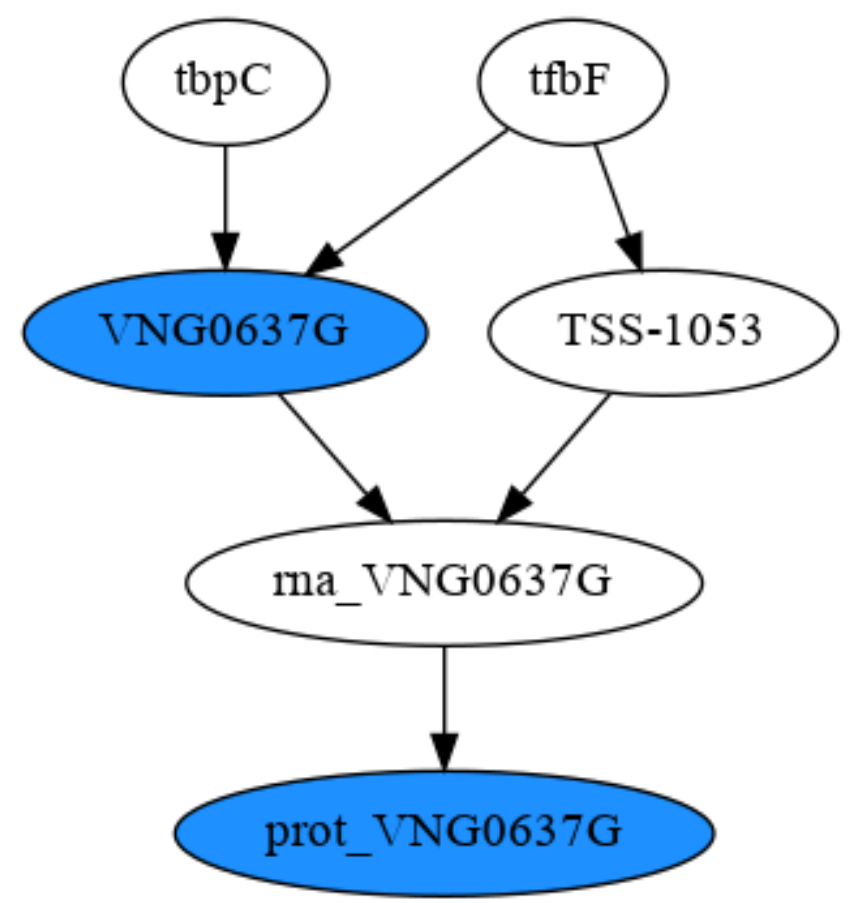

Figura 3.9 - Rede contendo interações dos experimentos ChIP-* e dRNA-seq para o gene VNG0637G. O nó com prefixo "TSS" representa o asRNA transcrito por este sítio de transcrição.

Uma segunda forma de regulação pós-transcricional que será incluída no modelo corresponde ao papel exercido pelos trans-RNAs. RNAs deste tipo conseguem desempenhar seu papel regulatório quando associados a proteínas cuja função é facilitar a ligação dos mesmos aos seus alvos. Uma proteína atuante neste mecanismo na $H$. salinarum é a LSm, uma chaperona responsável por expor os sítios de ligação do RNA regulador ao RNA alvo. Esta interação associada ao fino ajuste da regulação será obtida a partir dos dados pré-processados de RIP-seq, cujo resultado foi um conjunto de segmentos ditos enriquecidos (posições onde $\log _{2}($ ratio $) \geq 0$ ).

Devido às características do experimento, um critério natural de se adotar é estabelecer uma interação entre a LSm e um RNA através do cálculo da média dos segmentos enriquecidos que se encontram localizados dentro de uma região gênica anotada, estabelecendo de fato a relação caso o valor obtido esteja acima de um cutoff escolhido. Este processamento tem como hipótese subjacente que a biblioteca utilizada como referência para normalização do experimento RIP-seq refere-se a uma linhagem de $H$. salinarum sem a superexpressão da LSm, não havendo sentido considerar medições com $\log _{2}$ (ratio) $\leq 0$.

As extensões realizadas na estrutura exibida na Figura 3.10 são referentes a adição dos nós LSm e VNG1496G, responsáveis por representar a proteína de fato e o gene que a produz, onde a aresta existente entre LSM e rna_VNG0637G retrata o fenômeno físico de interação entre um complexo LSm-RNA e o RNA alvo.

A última interação incluída na rede corresponde a existente entre as diferentes 


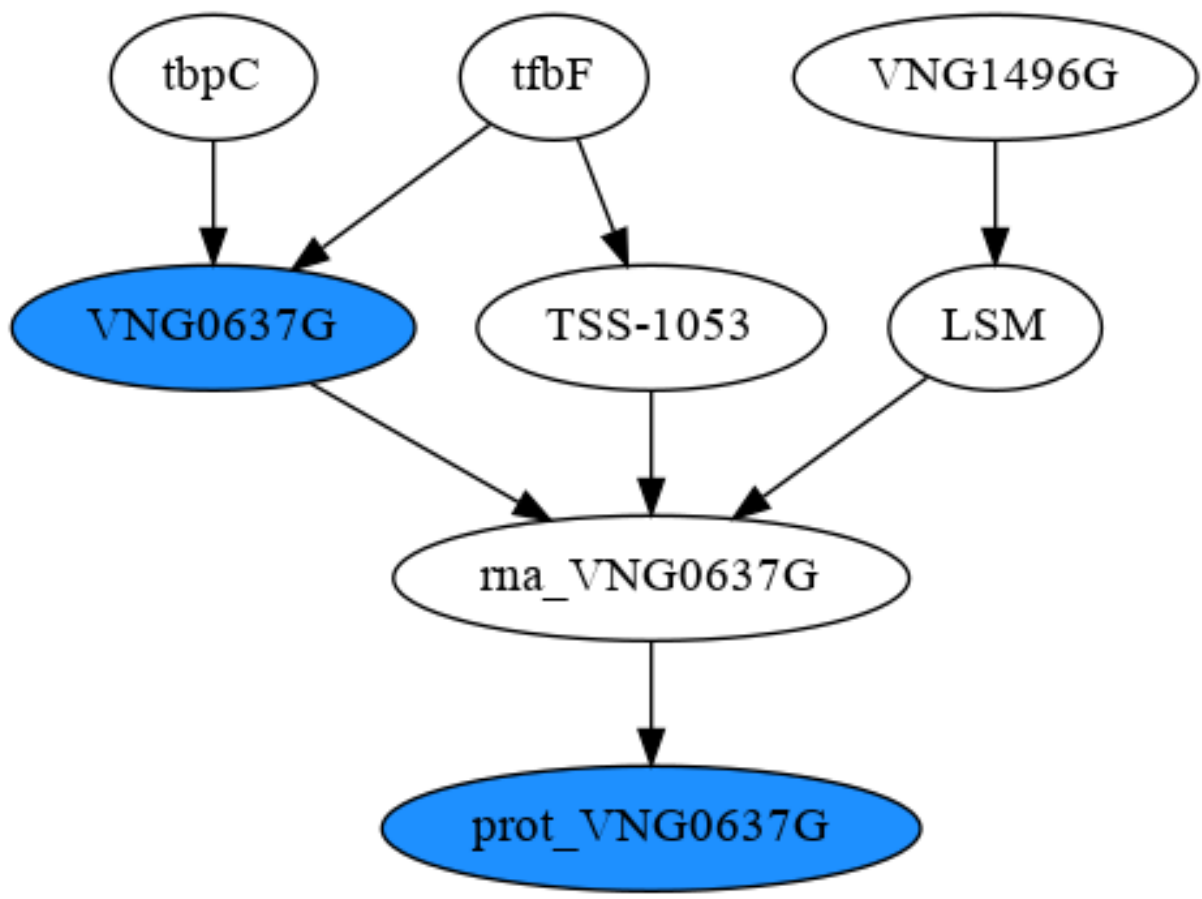

Figura 3.10 - Rede contendo interações dos experimentos ChIP-*, dRNA-seq e RIP-seq para o gene VNG0637G. Os nós LSM e VNG1496G representam a proteína e o gene que a codifica.

proteínas do organismo. Adicioná-las ao grafo é uma tarefa simples mediante o préprocessamento já realizado, fazendo com que o processamento desta etapa consista da extração dos valores contidos no arquivo de texto para um formato adequado (lista de arestas). A Figura 3.11 é um exemplo do resultado obtido nesta etapa, não havendo a adição de nenhum tipo novo de nó, apenas a inclusão de interações nos já existentes.

Como os grafos apresentados até o momento são apenas exemplos utilizados para facilitar a visualização das interações obtidas em cada uma das etapas, é necessário apresentar a estrutura global da rede final (Figura 3.12), contendo as interações descritas anteriormente para todos os genes. Vale destacar que a estrutura aqui proposta não é completa, isto é, diversas interações não foram incluídas, tendo como principal exemplo a ausência de vários TFs. Além, tendo em vista o paradigma de compreensão sistêmica do processo de regulação gênica, serão extraídas estatísticas comumente utilizadas na literatura [90,91]: coeficiente de clustering, quantidade média de vizinhos, diâmetro e componentes conexas.

Inicialmente proposta por Watts e Strogatz, pioneiros da área, o coeficiente de clustering $c(v)$ tinha como objetivo medir a probabilidade de dois vizinhos quaisquer de $v$ estarem conectados, entretanto, geralmente usa-se a versão "global", $C(G)$, definida como a média $c(v)$ sobre todos os nós. Segundo Costa et al. [92], algumas redes representando fenômenos biológicos tendem a apresentar altos valores, como a PPI da S. cerevisiae, cujo valor para o coeficiente é 0,18 , tal que $0 \leq c(v) \leq 1$. Sua definição é dada pela razão 


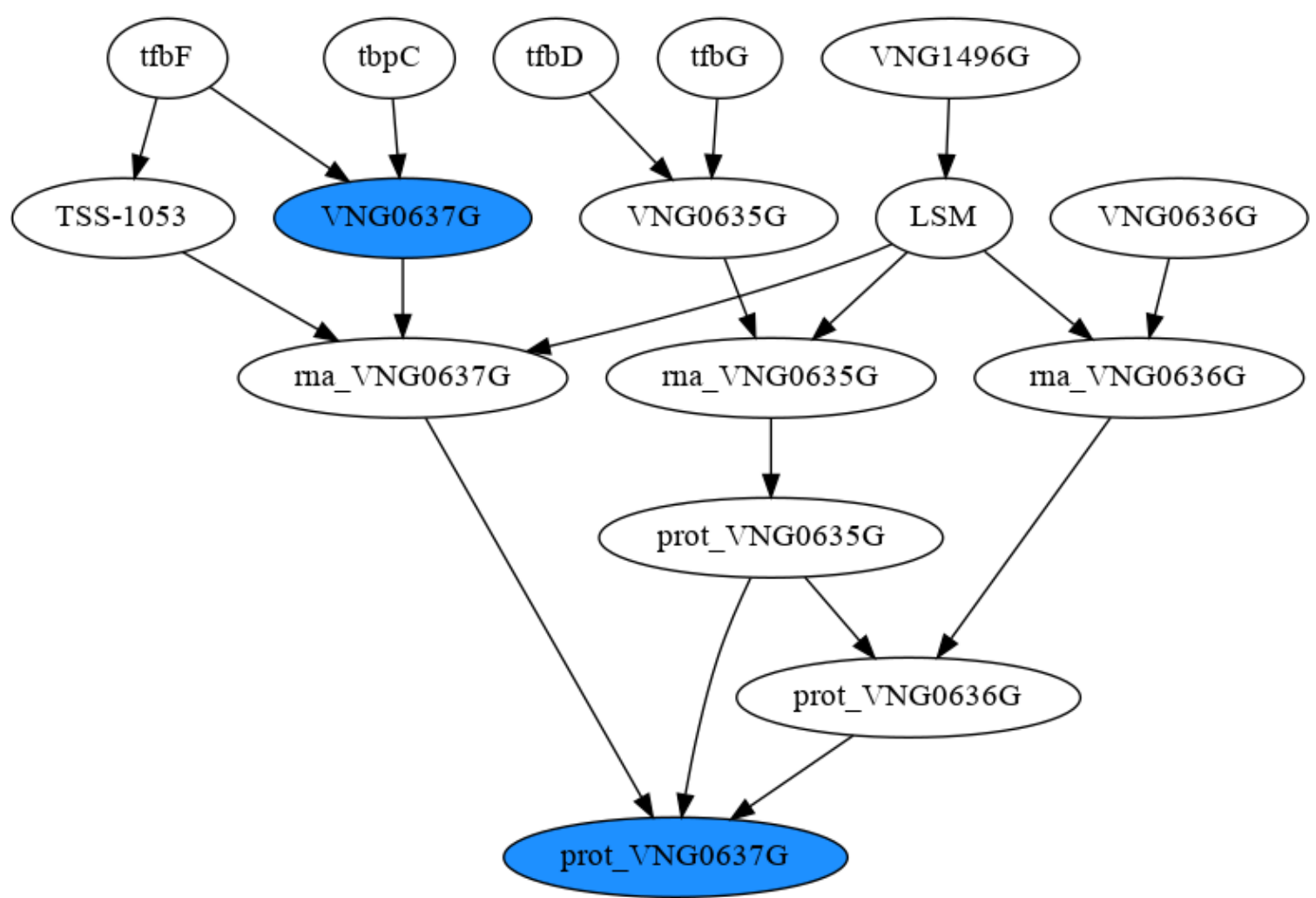

Figura 3.11 - Rede obtida através das relações extraídas de dados ChIP-* , dRNA-seq, RIP-seq e de interação Proteína-Proteína para o gene VNG0637G.

apresentada na Equação 3.1.

$$
c(v)=\frac{\text { Quantidade de arestas entre vizinhos }}{\text { Quantidade máxima de arestas entre vizinhos }}
$$

O grau de um nó $i$ é definido como a quantidade de nós que se conectam a ele, dada pela Equação 3.2. Além, no caso de um grafo direcionado a definição pode ser fragmentada em duas, uma para os nós incidentes de $i$ (mais conhecido em inglês in degree), e outra para os nós que $i$ incide (mais conhecido em inglês por out degree).

$$
k_{i}=\sum_{j} a_{i j}
$$

Uma extensão natural desta estatística local para uma global é considerar o grau médio de todos os nós da rede, dado pela Equação 3.3 .

$$
\langle k\rangle=\frac{1}{\mathrm{~N}} \sum_{i} k_{i}
$$

O diâmetro de uma rede é definido como o caminho mais longo dentre todos os caminhos mais curtos de uma rede. Desta forma, é a maior distância entre todos os pares 
de nós existentes na rede. Sua definição matemática é dada pela Equação 3.4.

$$
\operatorname{diam}(\mathcal{G})=\max \{d(u, v) \mid u, v \in V\}
$$

Os seguintes valores foram obtidos: 0,005, 3,070 e 9,0, respectivamente, para coeficiente de clustering, quantidade média de vizinhos e diâmetro. Uma vez que o objetivo da dissertação não é utilizar diretamente as estatísticas apresentadas, evitamos revisar profundamente estas e outras métricas, tendo em vista a vasta literatura de métricas para redes complexas, uma boa revisão em torno destas pode ser encontrada em Costa et al. [92].

A motivação que permeou o desenvolvimento da nova estrutura consistiu em incluir interações regulatórias até o momento inéditas, graças a dados não publicados de experimentos de interações físicas. A GRN proposta fornece um "mapa" regulatório mais condizente com o fenômeno físico, transferindo conhecimento a priori mais real para futuros desenhos experimentais de expressão gênica na $H$. salinarum, tendo em vista que as relações modeladas foram obtidas através de medições de interações físicas ou seus proxis, e, portanto podem ser consideradas como mais confiáveis que as estimadas computacionalmente, como nas abordagens tidas como estabelecidas.

Além dos resultados associados a criação da GRN da $H$. salinarum, um subproduto resultante da pergunta científica de interesse foi o conjunto de ferramentas desenvolvidas para o processamento e integração destes dados. O conjunto de scripts é responsável por implementar a série de critérios adotados nas etapas de processamento, permitindo que os mesmos sejam aplicados em outros organismos, desde que os dados estejam no padrão adotado pela ferramenta. 


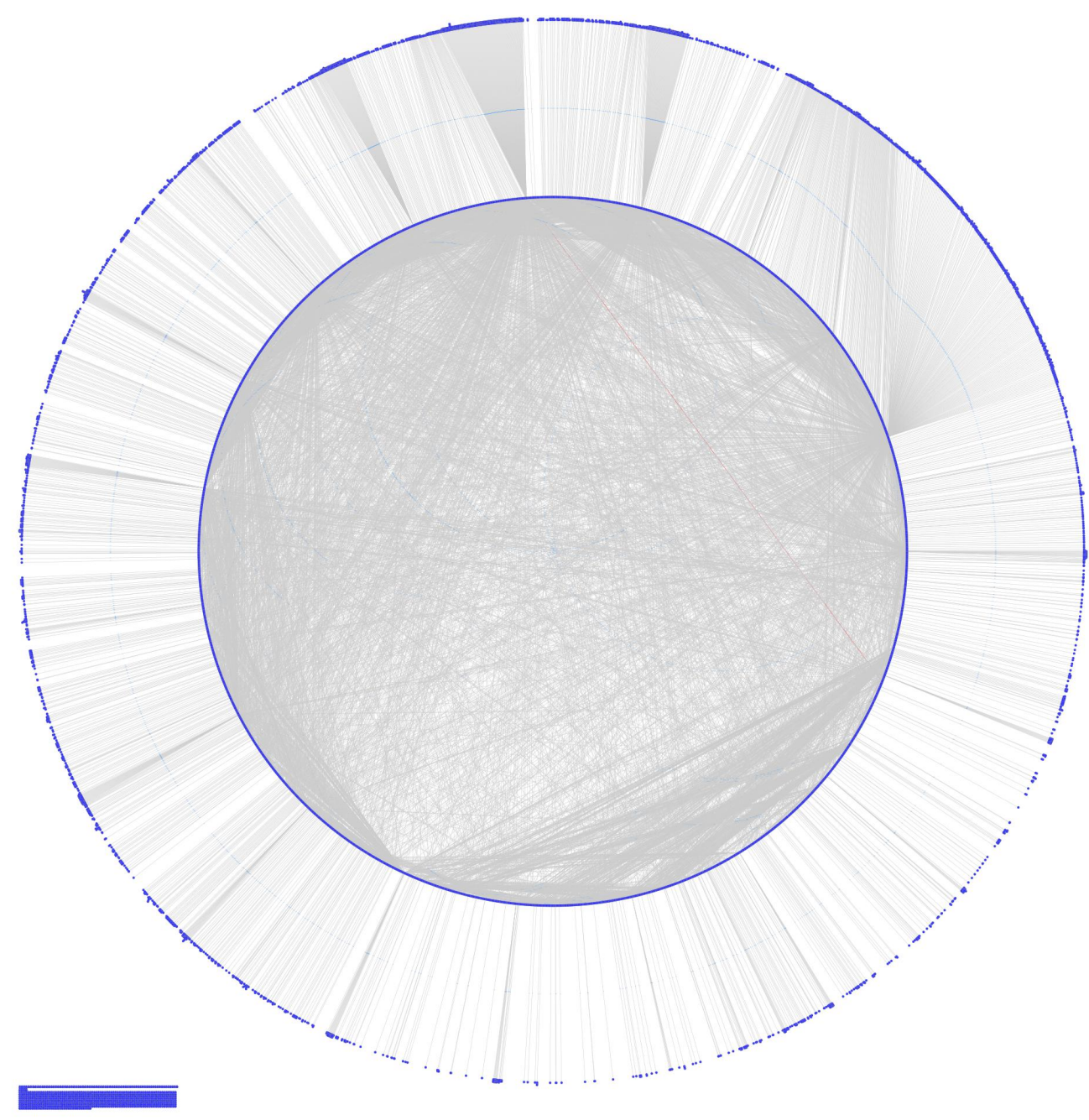

Figura 3.12 - Rede de Regulação Gênica proposta para a H. salinarum. A visualização foi obtida através da ferramenta Cytoscape, aplicando um layout circular sobre a estrutura do grafo que contém 9.097 nós (pontos em azul na figura) e 13.962 arestas. 


\section{Análise da Rede}

Uma motivação científica intrinsecamente associada a criação de uma GRN é a validação desta estrutura, seja por experimentos biológicos ou análises computacionais, buscando averiguar a qualidade das relações propostas. Como a estrutura resultante foi um DAG, o modelo de BN foi a escolha lógica para a análise, consistindo em estimar probabilidades a partir de dados de microarray para então identificar genes que são de fato controlados pelos reguladores propostos. Antes de discutir a análise probabilística, é necessário apresentar os dados utilizados para essa tarefa e contextualizá-los, apresentando o fenômeno da expressão gênica e as etapas experimentais necessárias para medi-lo.

\subsection{Descrição experimental}

Apesar dos recentes avanços no sequenciamento paralelo de larga escala (NGS, acrônimo para o termo em inglês next-generation sequencing), os dados utilizados por este trabalho contam exclusivamente com medições de tiling array. De forma geral os chips de microarray ainda são frequentemente utilizados, não somente devido à experiência e conforto dos pesquisadores, mas também por limitações ainda existentes no processamento e análise dos dados; e também pelo alto custo financeiro, onde os chips ainda são vantajosos, apesar da rápida queda dos preços para o NGS. O nome tiling array representa um dos múltiplos chips de microarray disponíveis, portanto, para descrevê-los é necessário primeiramente apresentar a tecnologia de microarranjos de DNA.

A tecnologia de microarranjos de DNA (microarray) vem sendo utilizada há vários anos em estudos de expressão gênica, sendo o grande responsável pela popularização e ampla disponibilidade de dados deste tipo. O sucesso desta tecnologia se deve em grande parte ao conceito bioquímico de hibridização específica de sequências de nucleotídeos: a ligação entre sequências complementares será estável, enquanto as não complementares, instáveis.

Num experimento de microarray, diversos genes de interesse são selecionados para que a partir de suas respectivas sequências sejam desenhadas sondas (DNA imobilizado) que detectarão a expressão do gene. Cada um destes detectores é fixado nos elementos da lâmina (mais conhecido em inglês por spots) para detectar o gene de interesse. Num cenário ideal, a correspondência sondas-genes deve ter o comportamento de uma relação bijetora, 
i.e., todos os genes são reconhecidos por uma única sonda. Entretanto, devido limitações técnicas do fenômeno de medição, ou por características da própria sonda, isso nem sempre é possível. Devido a alta precisão exigida para a tarefa, um robô é utilizado para posicionar as sondas nos spots, tal que sondas com a mesma sequência sejam posicionadas no mesmo spot - Figura 4.1(b).

A maneira mais comum para medir os níveis de expressão é através de amostras de RNA, exigindo que o mesmo seja transformado em cDNA, uma molécula sintética de DNA mais estável que o RNA complementar e facilmente obtida através da ação da transcriptase reversa. Durante a síntese de cDNA são incluídos nucleotídeos modificados, carregando moléculas fluorescentes (Cy3, Cy5), tornando possível a diferenciação visual dos grupos para posterior processamento computacional, esta etapa é conhecida como "marcação do RNA" - Figura 4.1(a).

O contato das moléculas fluorescentes com a lâmina faz com que as mesmas "visitem" os spots existentes, fixando-se somente naqueles onde existem sequências complementares, graças a propriedade da hibridização específica - Figura 4.1(b). Após a hibridização ocorre a excitação dos fluoróforos através de um laser, onde a intensidade de fluorescência do material capturado no detector é proporcional a quantidade de mRNA associado ao gene Figura 4.1(c).

A necessidade de quantificar a abundância de mRNA referente a uma condição referência surge da dificuldade de estimar a quantificação absoluta original. Este tipo de quantificação é conhecido como microarray "duas cores", uma vez que a medição final é uma razão entre a intensidade de uma população sobre a outra (referência ou controle). Excitar cada spot permite a análise computacional das imagens resultantes, que após o processamento computacional serão utilizadas para calcular o log ratio entre as duas amostras - Figura 4.1(d).

Outra técnica de microarranjo que merece destaque é o tiling array. Enquanto o chip clássico de microarray é utilizado para medir a expressão de genes específicos, no tiling array as sondas são desenhadas para cobrir uma região genômica, realizando a medição dos níveis de transcrição em todo o segmento, independente ou não da existência de um gene. As formas de posicionamento das sondas pode ser classificada de três maneiras: sobrepostas, espaçadas e fim-a-fim. Na Figura 4.2(a) há sobreposição das sondas, e consequentemente maior resolução experimental, já que diferentes sondas estão medindo a mesma região do genoma. A segunda forma, representada pela Figura 4.2(b), contém sondas alinhadas tal que o final da anterior toca o início da próxima, não ocorrendo sobreposição nem existindo espaçamento entre as mesmas. A organização com menor resolução é a espaçada (Figura 4.2(c)), onde existe um intervalo entre uma sonda e outra, variando o espaçamento conforme o custo ou necessidade do estudo.

Algumas aplicações típicas desta tecnologia são: identificação de novas sequências 


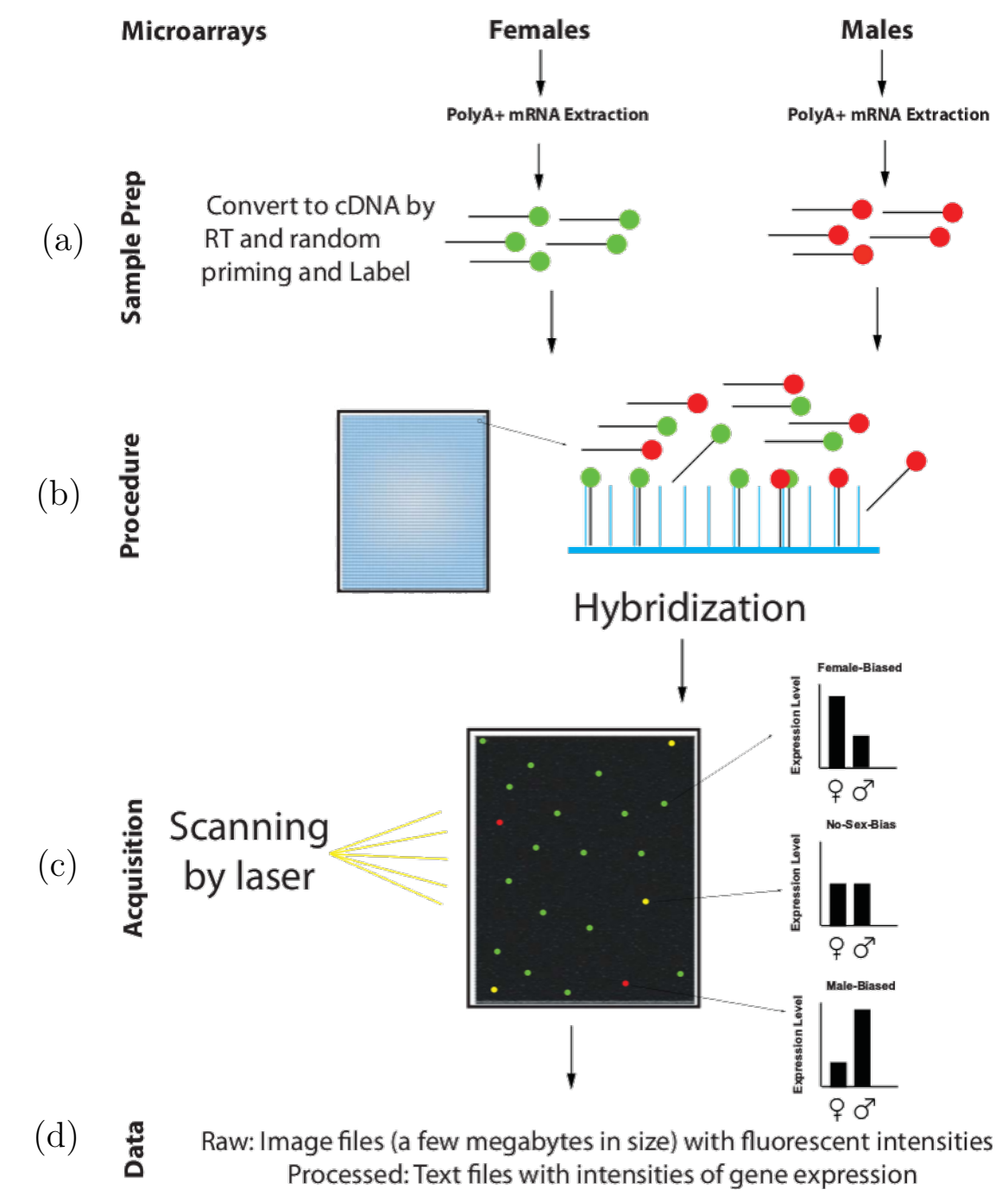

Figura 4.1 - Principais etapas do experimento microarray. (a) Extração do RNA obtido da célula e conversão em cDNA, cada círculo representa um gene, ou seja, o mesmo gene medido pelo spot verde (controle) será também medido pelo spot vermelho (condição de interesse). (b) Inserção das sondas na lâmina de microarray para hibridização. (c) Excitação dos fluorófilos através de um laser. (d) Análise computacional das imagens e conversão dos níveis de expressão (intensidade de fluorescência) para o formato de texto. Fonte: Malone e Oliver [93].

transcritas e elementos regulatórios; anotação experimental do genoma; e determinação da estrutura dos transcritos de genes. Outra aplicação bem sucedida ocorre através do acoplamento destes chips com o protocolo ChIP, tornando possível identificar sítios de ligação com o DNA ao longo do genoma, como já descrito anteriormente. Ainda, vale destacar que as etapas experimentais deste método são equivalentes a do microarray, tendo em vista que os fundamentos envolvidos são iguais, distinguindo-se somente pelo tipo de chip utilizado. 


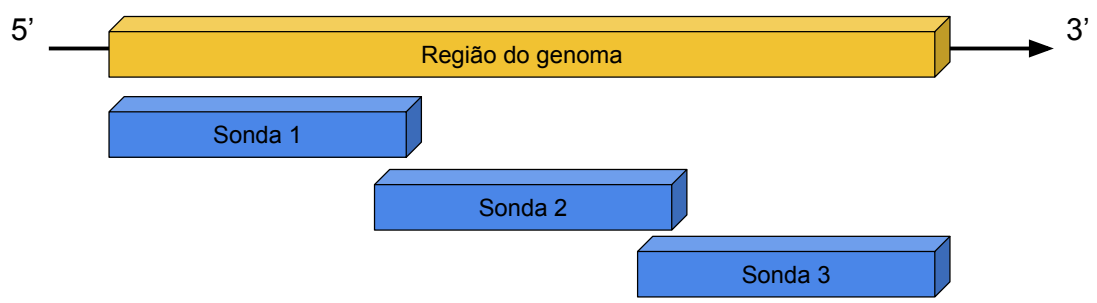

(a) Sobrepostas

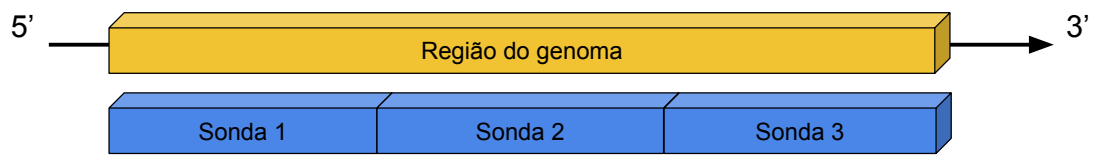

(b) Fim-a-fim

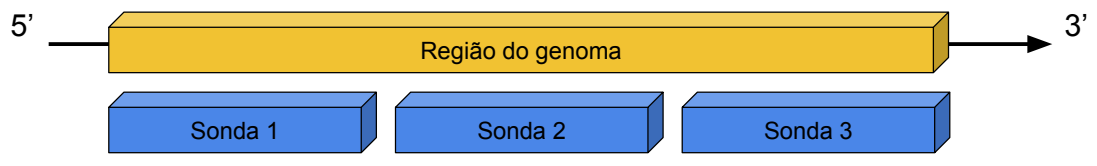

(c) Espaçadas

Figura 4.2 - Tipos de posicionamento para sondas de tiling array. (a) Posicionamento tipo sobreposto, há sobreposição entre as sondas, existindo uma ou mais medições para a mesma posição. (b) Posicionamento tipo fim-a-fim, não há espaçamento nem sobreposição das sondas. (c) Posicionamento tipo espaçado, há espaçamento entre a posição final de uma sonda e a posição inicial da próxima.

\subsection{Obtenção e processamento dos dados}

As primeiras medições utilizando tiling array em H. salinarum foram disponibilizadas através de Koide et al. [80], e desde então houve uma crescente popularização no uso desta metodologia para medir os níveis de transcrição de um organismo, de forma geral em grande parte devido às razões citadas previamente, mas em específico para este trabalho, uma, que é a possibilidade de conseguir quantificar o nível de expressão de genes que foram reanotados ou anotados pela primeira vez.

Os seguintes dados públicos de tiling array foram utilizados neste trabalho: (i) 12 medições colhidas durante a curva de crescimento [80]; (ii) 1 medição superexpressando tfbD [80]; (iii) 4 medições sob estresse oxidativo [83]; (iv) 9 medições obtidas alterando a salinidade do ambiente [94]; (v) 2 medições sobre o papel do gene VNG2099, codificador da proteína RNAse [95]; (vi) 4 medições obtidas após deleção de TFs [96]; (vii) 3 medições alterando a concentração nos níveis de oxigênio - não publicados; (viii) 4 medições sobre o papel do gene VNG1496G, codificador da LSm - não publicados.

As oito condições ambientais distintas fornecem um total de 38 medições para cada um dos genes. Cada condição utilizou uma resolução diferente, medindo os níveis de 
expressão para os três cromossomos da H. salinarum. Uma descrição compilada destes experimentos pode ser encontrada na Tabela 3.

\begin{tabular}{lccc}
\hline Condição & GEO & $\Delta t$ & Referência \\
\hline Curva de crescimento & GSE12923 & 12 & Koide et al. [80] \\
Superexpressão tfbD & GSE15788 & 1 & Koide et al. [80] \\
Estresse oxidativo & GSE61975 & 4 & Plaisier et al. [83] \\
Alteração de salinidade & GSE53544 & 9 & Beer et al. [94] \\
$\Delta$ VNG2099 (RNAse) & GSE45988 & 2 & Wurtmann et al. [95] \\
Deleção de TFs & GSE31308 & 4 & Turkarslan et al. [96] \\
Alteração de oxigênio & - & 3 & Não publicado \\
$\Delta$ lsm & - & 4 & Não publicado \\
\hline Total & - & 39 & -
\end{tabular}

Tabela 3 - Dados de tiling array para Halobacterium salinarum NRC-1.

É importante destacar que todos os experimentos foram normalizados utilizando uma única condição referência $(\mathrm{DO}=0.6$ colhidas durante a primeira fase $l o g$ de crescimento) [80], fato que pode parecer estranho num primeiro momento, entretanto, a justificativa reside na tentativa de criar uma base de experimentos onde todos possam ser comparáveis, de tal forma que ao longo do tempo fosse possível obter um conhecimento sólido a respeito dos mecanismos de regulação.

O $\log$ ratio de cada sonda $\left(\log _{2} \frac{\text { curva crescimento }}{\text { curva referência }}\right)$ foi calculado após a normalização quantil dos experimentos. Esta técnica é amplamente utilizada e foi desenvolvida especificamente para experimentos de expressão gênica via microarray, mas sua aplicação estendeu-se rapidamente para outras áreas. Os fundamentos desta normalização residem na suposição de que variações globais existentes entre os experimentos são resultados de limitações técnicas, e por isso devem ser removidas; e que as distribuições estatísticas dos experimentos são iguais. Especificamente, as distribuições observadas são "forçadas" a serem iguais à distribuição média, obtida através da média dos quantis [97].

Os valores obtidos após a normalização são números reais representando a variação fold da sonda, entretanto, uma limitação importante de BNs é sua incapacidade de representar interações complexas para distribuições de probabilidade contínuas. A "versão" contínua de BNs recebe o nome de Redes Bayesianas Gaussianas, que assume que cada uma das variáveis é normalmente distribuída. Neste modelo, a decomposição da distribuição conjunta em condicionais deve ser normal, com média igual à combinação linear dos pais da variável de interesse: $P\left(Y \mid X_{i} \ldots X_{k}\right)=\mathcal{N}\left(\sum_{i=1}^{k} \beta_{i} X_{i}+\beta_{0} ; \sigma^{2}\right)$. Esta imposição limita consideravelmente a representação do fenômeno biológico, uma vez que boa parte dos mecanismos de regulação estão associados a interações altamente complexas e não lineares.

Uma alternativa importante e bem conhecida na literatura para enfrentar esta limitação é o emprego do modelo multinomial de BNs. Nele, cada distribuição condicional 
será representada por uma multinomial com estados arbitrários e finitos. Apesar da perda de informação inerente ao procedimento de discretização, dois benefícios desta escolha quando comparada com a alternativa contínua são: melhor representação do fenômeno modelado, uma vez que se limitar a interações lineares não condiz com a realidade do problema; menor custo computacional devido à limitação de estados finitos, permitindo que mais entidades sejam incluídas e consequentemente analisadas pelo modelo.

Tendo em vista as limitações representativas e computacionais do modelo contínuo, este trabalho empregará o modelo multinomial com os três estados representativos: "+1", para genes upregulated; "0" para genes que não apresentam variação significativa dos níveis de expressão; "-1", para genes downregulated. Desta forma, uma etapa importante no processamento foi a escolha adequada do método e dos valores de discretização ( $c u$ toff), considerando para a decisão o fato que pequenas alterações são capazes de alterar significativamente o comportamento do organismo.

Os seguintes métodos foram implementados para discretizar os dados: discretização com desvio padrão local e global; discretização fold change; e discretização duas médias [98]. Nos procedimentos baseados no desvio padrão, os instantes de tempo foram discretizados quando seus respectivos valores estavam acima ou abaixo de uma quantidade escolhida de desvios padrão. Seja $g(t)$ o nível de expressão de um gene, $\mu$ a média, $\sigma$ o desvio padrão e $\alpha$ um número real, a quantificação assumida pela discretização $g^{\prime}(t)$ é dada pela Equação 4.1.

$$
g^{\prime}(t)= \begin{cases}+1, & \text { se } g(t) \geq \mu+\alpha \cdot \sigma \\ 0, & \text { se } \mu-\alpha \cdot \sigma \leq g(t) \leq \mu+\alpha \cdot \sigma \\ -1, & \text { se } g(t) \leq \mu-\alpha \cdot \sigma\end{cases}
$$

A diferença existente entre a abordagem "global" e "local" baseia-se em como a média e o desvio padrão são calculados. No global, as estimativas da média e do desvio padrão são calculadas considerando todas as amostras, enquanto na alternativa local, a média e o desvio padrão são estimados para cada amostra. A motivação de uso do método local reside na menor variação nos níveis de expressão dos genes que são TFs, e portanto faz sentido limitar a média aos valores de expressão do experimento.

A discretização fold change baseia-se na bem conhecida e amplamente utilizada "regra 2-fold" para detecção de genes diferencialmente expressos. Esta estratégia consiste na escolha de uma razão arbitrária (threshold - usualmente de 2 vezes) que será utilizada como corte, onde os genes com razão acima deste valor são considerados diferencialmente expressos. A adaptação desta regra para a discretização consiste na simples alteração dos valores dos genes acima do threshold para os valores +1 e -1 , representando genes nos estados upregulated e downregulated. Este procedimento é resumido matematicamente pela 
Equação 4.2 .

$$
g^{\prime}(t)= \begin{cases}+1, & \text { se } g(t)>\log _{2}(\text { fold }) \\ 0, & \text { se }-\log _{2}(\text { fold }) \leq g(t) \leq \log _{2}(\text { fold }) \\ -1, & \text { se } g(t)<-\log _{2}(\text { fold })\end{cases}
$$

A discretização com duas médias baseia-se no método proposto por MartinsJr [98]. Neste trabalho são calculadas duas médias, uma para os valores de expressão gênica positivos $(h)$ e outra para os negativos $(l)$. A partir destes valores os intervalos de discretização são definidos de acordo com a Equação 4.3.

$$
g^{\prime}(t)= \begin{cases}+1, & \text { se } g(t)>h \\ 0, & \text { se } l \leq g(t) \leq h \\ -1, & \text { se } g(t)<l\end{cases}
$$

A importância de construir as CPTs (subseção 2.2.4) através de diferentes procedimentos de discretização está na necessidade de explorar a perda de informação sob diferentes prismas, já que de forma geral identificar o melhor método e threshold é um processo empírico guiado pela avaliação dos resultados, e portanto totalmente dependente dos dados utilizados.

\subsection{Tabelas de Probabilidade Condicionais}

Para que a análise das CPTs seja possível é necessário primeiramente construir uma BN. Para tal, dois elementos básicos são necessários (subseção 2.2.4): a parte quantitativa, representada pelas medições de expressão gênica discretizadas; e qualitativa, que fornecerá as relações de controle entre os genes e seus reguladores conhecidos. Uma escolha natural seria adotar a GRN proposta no capítulo anterior, mas como a ideia foi representar o fenômeno biológico da regulação gênica, não houve preocupação alguma sobre a existência ou não de medidas associadas a cada "classe" de nó, fator essencial a análise neste capítulo. Outro item que merece reforço, é que as relações existentes na rede escolhida, e dada a priori, não foram em nenhum momento inferidas, mas sim obtidas exclusivamente de medições de interações físicas (Capítulo 3).

Tendo em vista os dados escolhidos para análise neste capítulo, é necessário realizar simplificações na estrutura da rede proposta. As simplificações referem-se a exclusão de nós que representam os RNAs e as proteínas. Manter os primeiros é desnecessário, uma vez que podemos associar (sem perda de sentido) os níveis de transcrição ao próprio nó que representa o gene, o que matematicamente é equivalente a assumir que $\operatorname{Pr}($ Gene $\mid$ TFs $) \equiv$ Pr(rna_Gene | TFs). Já os nós que representam proteínas serão descartados porque não 
há uma quantidade estatisticamente significativa de experimentos de proteômica sob as mesmas condições experimentais de transcritômica (apenas [99]).

O critério de simplificação adotado encontra-se ilustrado pela Figura 4.3, sendo importante destacar mais uma vez que este é apenas um exemplo, e que o mesmo procedimento foi utilizado globalmente. Além disso, um fato que merece atenção na figura é a presença dos nós que representam os TFs, o que de fato é uma imprecisão biológica, pois, estes também são proteínas codificadas por genes, mas é uma imposição necessária para que a estrutura não contenha nenhum ciclo.

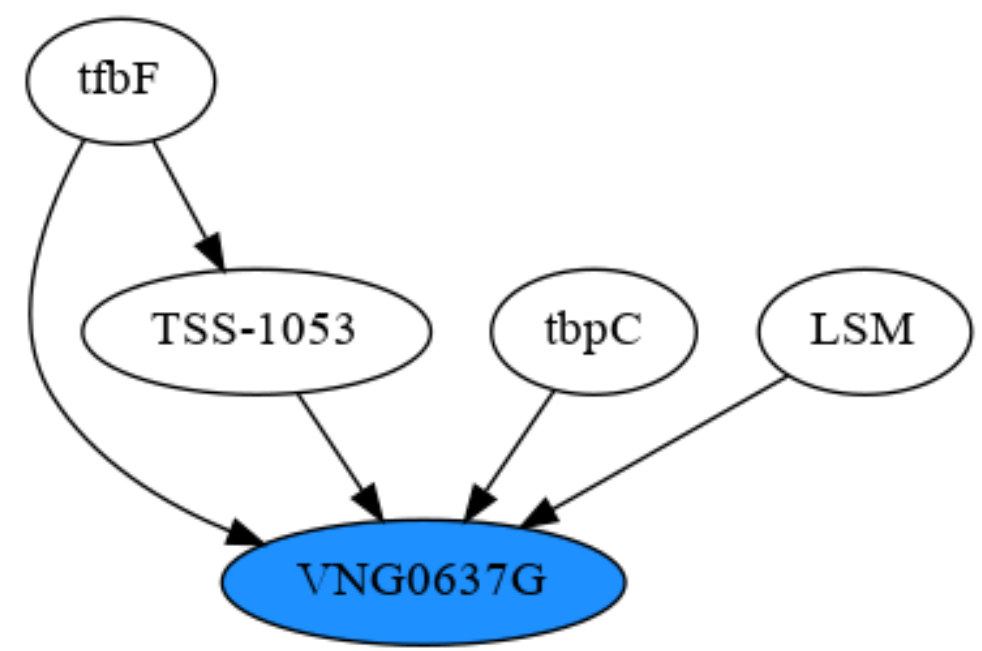

Figura 4.3 - Exemplo de BN utilizada na análise probabilística. A estrutura exibida é um exemplo da simplificação realizada na estrutura da etapa anterior, consistindo na remoção dos nós que representavam os RNAs e as proteínas.

Como consequência desta escolha, a GRN original será representada pelo modelo probabilístico de BNs, o que tornará possível responder se é plausível ou não determinar o estado transcricional de um gene a partir de seus reguladores conhecidos. Sejam $G$ e $T F$ variáveis aleatórias representando um gene e um TF, a Equação 4.4 representa matematicamente o fenômeno da regulação sob a ótica de BNs.

$$
P\left(G_{1}, \ldots, G_{k}, T F_{1}, \ldots, T F_{n}\right)=\prod_{i=1}^{k} P\left(G_{i} \mid P a\left(G_{i}\right)\right) \prod_{j=1}^{n} P\left(T F_{j}\right)
$$

Vale destacar que como a BN é uma representação do fenômeno de regulação gênica, a função $P a($.$) pode ser interpretada como os reguladores do nó de interesse, uma$ vez que agora os ancestrais de um nó representam os reguladores (TFs) do mesmo. Em termos quantitativos, a rede contém 2.781 nós e 6.554 arestas. Como a análise consiste em avaliar a BN sob a ótica do modelo multinomial, uma escolha natural para inferir as probabilidades de cada distribuição condicional é através da estimativa de máxima verossimilhança. 
O método de máxima verossimilhança é um importante conceito estatístico associado a estimativa de parâmetros de um modelo, dado um conjunto de observações. As estimativas dos parâmetros são obtidas através da maximização da função de verossimilhança em relação ao modelo, o que de forma geral resulta em estimativas que maximizam a probabilidade das observações sob a distribuição imposta sob o mesmo. Como esperado, este princípio também é aplicado para estimar os parâmetros de uma BN. O estimador de máxima verossimilhança para as distribuições de probabilidade condicionais (mais conhecida em inglês como conditional probability distribution - CPD) é dado pela Equação 4.5.

$$
\begin{aligned}
\mathcal{L}\left(\theta_{X \mid U}: D\right) & =\prod_{x \in \operatorname{Val}(X), u \in \operatorname{Val}(U)} \theta_{x \mid u} \\
\hat{\theta}_{x \mid u} & =\prod_{u \in \operatorname{Val}(U)}\left[\prod_{x \in \operatorname{Val}(X)} \theta_{x \mid u}^{M[u, x]}\right] \\
\hat{\theta}_{x \mid u} & =\frac{M[x, u]}{\sum_{x \in \operatorname{Val}(X)} M[x, u]}
\end{aligned}
$$

Onde $x$ é uma variável não terminal da rede (gene), $u=\operatorname{Pa}(x)$ e $M[x, u]=$ $\sum_{m} \mathbb{1}\{X[m]=x, U[m]=u\}$, ou seja, a contagem do número de casos em que as variáveis aleatórias $X$ e $U$ são iguais aos valores observados. Assim, o estimador de máxima verossimilhança para a CPD multinomial corresponde a uma "simples" contagem do número de vezes que o estado do nó condicionado aos estados de seus pais são observados nos dados, normalizando pela quantidade de observações dos estados dos ancestrais. Para variáveis terminais (TFs) a derivação é mais simples e equivalente ao estimador de máxima verossimilhança de uma variável multinomial. As etapas completas para cada tipo de variável podem ser encontradas em [52].

Um importante efeito negativo surge ao admitir que os genes são regulados de forma combinatorial por seus controladores: a quantidade de estados cresce exponencialmente com o número de reguladores. Este fato exige que sejam admitidas restrições computacionais para limitar a quantidade máxima de controladores associados a um gene, tornando a representação uma aproximação do verdadeiro fenômeno biológico.

Outra consequência deste crescimento é a diminuição exponencial do número de observações de uma instância. Este fenômeno é amplamente conhecido na literatura por dois nomes, o Problema da Fragmentação dos Dados ou a Maldição da Dimensionalidade, ambos referindo-se a maneira com que estes pontos encontram-se distribuídos num espaço altamente particionado pela enorme quantidade de dimensões. Um problema inerente deste fenômeno é a incapacidade de estimar os parâmetros de forma confiável, sendo uma limitação chave no aprendizado da estrutura de Redes Bayesianas a partir de valores numéricos [56]. 


\begin{tabular}{cccll}
\hline VNG1830G $=-1$ & VNG1830G $=0$ & VNG1830G $=+1$ & & \\
\hline $0.33 \overline{3}$ & $0.66 \overline{6}$ & 0.0 & $\mathrm{tfbD}=-1$ & TSS-2547=-1 \\
$0.33 \overline{3}$ & $0.33 \overline{3}$ & $0.33 \overline{3}$ & $\mathrm{tfbD}=-1$ & TSS-2547 $=0$ \\
$0.33 \overline{3}$ & $0.33 \overline{3}$ & $0.33 \overline{3}$ & $\mathrm{tfbD}=-1$ & $\mathrm{TSS}-2547=+1$ \\
$0.33 \overline{3}$ & $0.33 \overline{3}$ & $0.33 \overline{3}$ & $\mathrm{tfbD}=0$ & $\mathrm{TSS}-2547=-1$ \\
0.25 & 0.75 & 0.0 & $\mathrm{tfbD}=0$ & $\mathrm{TSS}-2547=0$ \\
0.0 & 1.0 & 0.0 & $\mathrm{tfbD}=0$ & $\mathrm{TSS}-2547=+1$ \\
0.0 & 1.0 & 0.0 & $\mathrm{tfbD}=+1$ & $\mathrm{TSS}-2547=-1$ \\
0.625 & 0.375 & 0.0 & $\mathrm{tfbD}=+1$ & $\mathrm{TSS}-2547=0$ \\
0.0 & 1.0 & 0.0 & $\mathrm{tfbD}=+1$ & $\mathrm{TSS}-2547=+1$ \\
\hline
\end{tabular}

Tabela 4 - Exemplo de CPT representando a regulação do gene VNG1830G.

Uma imposição necessária para estimar os parâmetros de forma correta é a presunção de independência estatística entre os distintos experimentos, tanto por serem executados em diferentes condições experimentais ou coletados em múltiplos instantes de tempo na mesma condição. Assumir este fato como verdadeiro não é totalmente condizente com o fenômeno biológico medido, principalmente quando se considera a independência entre os instantes de tempo, mas é uma imposição necessária para viabilizar a estimativa destes parâmetros.

Para que fosse possível responder a pergunta científica de interesse, era necessário primeiramente desenvolver o ferramental computacional essencial à análise. A escolha da linguagem Python como base deve-se principalmente à disponibilidade da biblioteca PGMPY [100], que implementa o modelo de BNs. Decisão tomada principalmente em vista das possibilidades futuras do projeto, uma vez que além de Redes Bayesianas, também são disponibilizados outros, como DBNs e Campos de Markov, que poderão ser utilizados no futuro como modelo base de análise da rede.

A Tabela 4 apresenta uma CPT resultante do aprendizado das probabilidades. Sua leitura deve ser efetuada da seguinte forma: P(VNG1830G | tfbD, TSS-2547), lendo primeiramente o cabeçalho e então a combinação de estados à direita. No total, 2.781 tabelas foram obtidas, uma para cada um dos nós na rede.

Um detalhe sutil, mas importante, é a representação do caráter combinatorial da regulação gênica, sendo uma tentativa de simular o real fenômeno biológico, onde o estado do gene é completamente dependente da combinação dos seus reguladores. Desta forma, se de fato o gene for controlado pelos reguladores sugeridos, então a probabilidade observada se concentrará num único estado do gene, deslocando-se para outro a partir da modificação nos seus reguladores, mas sempre permanecendo concentrada num único. Observar este efeito dependerá de dois fatores, a escolha adequada dos controladores e a qualidade da estimativa.

Como o método de estimação escolhido para construir as tabelas baseou-se na 
estimativa de máxima verossimilhança, é importante que antes da análise seja realizada uma etapa de processamento da CPT, tendo em vista a pequena quantidade de amostras em relação ao número de estados. Desta forma, as probabilidades serão calculadas num segundo momento, após a aplicação de um filtro cujo objetivo é eliminar linhas em que o número absoluto de observações está abaixo de um limite predeterminado, que nesta análise será de 6 observações, ou $15 \%$ da quantidade de experimentos.

Um critério amplamente conhecido capaz de medir a concentração de uma distribuição de probabilidade é a entropia de Shannon. A entropia de uma variável aleatória representa o grau de desordem (incerteza) associado a mesma. Dizer que existe alta incerteza associada a uma distribuição de probabilidade significa que as probabilidade associadas aos diferentes estados são muito similares, ou no caso extremo, iguais (Distribuição Uniforme). Uma maneira de medir a entropia de uma variável é dado pela Equação 4.6, conhecida como Entropia normalizada. Utilizar esta medida permite que a entropia de variáveis com diferentes estados sejam comparáveis, o que não fornece nenhum benefício imediato para a análise apresentada, mas servindo de base para futuras modelagens que não assumam uma quantidade idêntica de estados.

$$
\eta(X)=-\sum_{i=1}^{n} \frac{p\left(x_{i}\right) \cdot \log _{b}\left(p\left(x_{i}\right)\right)}{\log _{b}(n)}
$$

A análise das tabelas para identificar genes que são realmente controlados pelos reguladores propostos será realizada em duas etapas: a primeira consiste em calcular a entropia da variável gene para cada combinação de estados dos controladores, desconsiderando o estado "0" da variável, uma vez que este não fornece informação útil sobre o controle; então o valor mínimo de entropia (onde $b=2$ ) da tabela será comparado ao cutoff previamente estabelecido, dizendo que um gene é controlado por seus reguladores caso o mínimo seja maior que este valor.

Esta análise será aplicada nas tabelas computadas através dos diferentes conjuntos de dados gerados pelos distintos métodos de discretização. Especificamente, a análise foi realizada nos seguintes dados: fold com limiar 1,5; desvio padrão local com limiares 0,5 , 1,0, 1,5 e 2,0; desvio padrão global com limiares 0,5, 1,0, 1,5 e 2,0; e duas médias (sem limiar). O cutoff escolhido para a entropia foi de 0,3 .

O resultado obtido por esta análise foi um conjunto de genes considerados como de fato regulados pelos controladores sugeridos. Um exemplo de tabela que apresenta este fenômeno pode ser visto na Tabela 5, enquanto a Figura 4.4 exibe de forma compilada a quantidade de tabelas identificadas por cada método e limiar de discretização.

Através da Figura 4.4 é possível averiguar que o desvio padrão global ao nível 0,5 foi o que detectou mais tabelas, 72, correspondendo a um pequeno percentual do número total de nós da rede (2.781). Os resultados apresentados fornecem evidências contrárias a 


\begin{tabular}{cccl}
\hline VNG1314H=-1 & VNG1314H=0 & VNG1314H=+1 & \\
\hline 1.0 & 0.0 & 0.0 & $\mathrm{tfbG}=-1$ \\
0.1304 & 0.7826 & 0.0869 & $\mathrm{tfbG}=0$ \\
0.0 & 0.0714 & 0.9285 & $\mathrm{tfbG}=+1$ \\
\hline
\end{tabular}

Tabela 5 - Exemplo de CPT identificada através da análise.

utilização de BNs como modelo para identificação de genes controlados pelos reguladores propostos, uma vez que a abordagem mostrou-se incapaz de detectar de forma geral os controladores de um gene, apesar da grande quantidade (relativa a experimentos em outros organismos) de interações físicas existentes para a $H$. salinarum.

Mediante os resultados obtidos, foram estabelecidas duas principais causas para explicar este comportamento: uma quantidade pequena de experimentos de hibridização (38), resultando em estimativas de probabilidade que podem não representar o fenômeno físico, por conseguinte prejudicando a análise; e a quantidade insuficiente de interações físicas entre os controladores e os genes, impossibilitando a identificação dos reais reguladores de um gene. Para verificar se de fato o problema reside nos dados ou no modelo escolhido para representar o problema, aplicamos a mesma metodologia em outros organismos, o que validará a escolha.

A apuração de ambas as hipóteses encontram-se disponíveis na seção de apêndices desta dissertação. O Apêndice A trata da avaliação de uma BN aplicada num conjunto maior de dados de hibridização, onde 1.495 medições de microarray para a H. salinarum foram utilizadas para estimar as CPTs [2], através da mesma pipeline estabelecida previamente.

O Apêndice B refere-se a averiguação da quantidade insuficiente de medições de interações físicas, correspondendo a aplicação de BNs em medições publicamente disponíveis para a bactéria patógena Mycobacterium tuberculosis, organismo que até o momento apresenta a maior quantidade relativa de interações físicas medidas para seus TFs, 206 (de um total de 214), contando também com medições de hibridização realizadas nas mesmas condições experimentais [101].

Os resultados obtidos em ambos os apêndices não foram suficientes para confirmar o presente método como mecanismo geral para detecção de genes, fornecendo evidências contrárias a aplicação de CPTs e, portanto, BNs, para o objetivo proposto neste capítulo. Três hipóteses são sugeridas para explicar a observação deste fenômeno: a perda de informação associada a discretização dos dados, não refletindo a sutileza do fenômeno da expressão gênica; a maldição da dimensionalidade, exigindo uma quantidade de medições de hibridização indisponível para a maioria dos organismos, uma vez que na abordagem proposta o número de estados de controle cresce exponencialmente $\left(3^{n}\right.$, onde $n$ é a quantidade de reguladores do gene); e por último, o fenômeno da ligação inativa (dormant binding em tradução livre) [101]). 
O termo ligação inativa, surgiu após a observação de que algumas ligações físicas entre TFs e o DNA não produziam alteração alguma aos níveis de expressão, sugerindo que estes TFs estejam associados a condições ambientas específicas ou ao fino ajuste da expressão gênica.

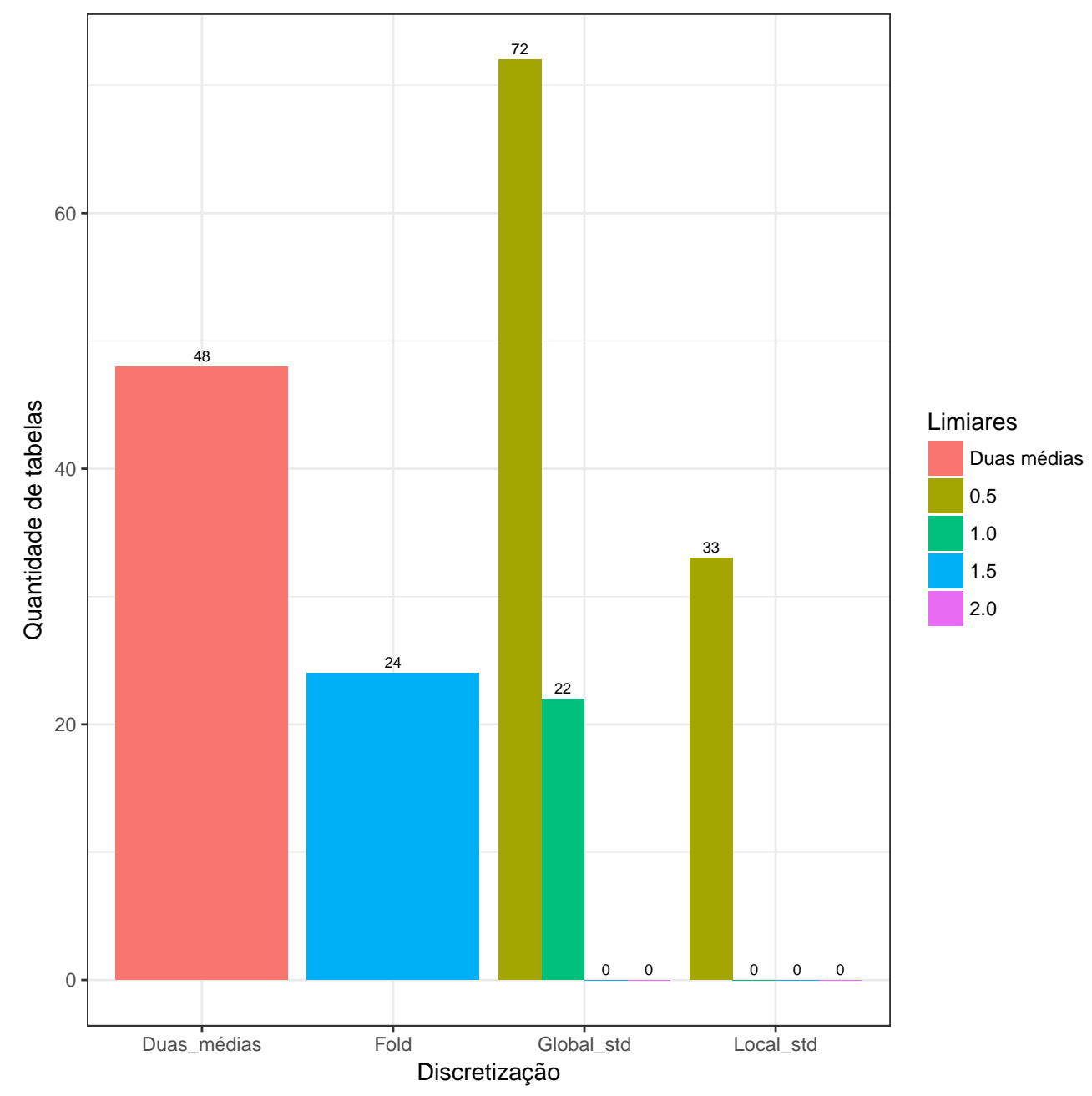

Figura 4.4 - Genes classificados como controlados pelos reguladores propostos. Estes valores foram obtidos através da análise de entropia nas tabelas computadas nos dados de tiling array discretizados.

Por fim, é importante destacar que, assim como no capítulo anterior, além da sistemática proposta para analisar as tabelas representando o comportamento de expressão de um gene, um subproduto resultante foi o conjunto de scripts capazes de analisar CPTs de uma BN. Estas ferramentas foram implementadas de forma genérica, permitindo a aplicação em outros organismos (Apêndices A e B). 


\section{Conclusão e Perspectivas}

O principal objetivo desta dissertação, estabelecer uma nova GRN para o organismo H. salinarum, através de conceitos da área de Biologia Sistêmica, foi considerado bemsucedido. Já o objetivo secundário, a identificação automática de genes controlados pelos reguladores propostos através dos fundamentos teóricos de Redes Bayesianas (BN), foi considerado malsucedido. Assim, conclui-se que apenas um dos objetivos propostos foi alcançado efetivamente.

De forma compilada, as contribuições desta dissertação à Bioinformática são:

1. a criação, através de dados inéditos, de uma nova Rede de Regulação Gênica (GRN) para a H. salinarum;

2. a implementação de diversos métodos capazes de processar e integrar dados de diferentes origens experimentais para o modelo sistêmico de GRN numa única ferramenta, cujo código fonte encontra-se disponível abertamente;

3. a implementação de um método de análise de CPTs com viés biológico, responsável por identificar genes que são de fato controlados pelos reguladores propostos.

Em se tratando da GRN criada, a alternativa que aparenta ser a mais interessante refere-se a inclusão de novas interações físicas de TFs. Apesar da modelagem atual ter incluído dados de todos os TFs básicos e alguns poucos específicos, foi verificado pela análise das CPTs que este conjunto está longe de ser suficiente para a simular computacionalmente o comportamento da H. salinarum. Assim, uma extensão natural seria incluir interações obtidas através de novos experimentos de interação física (preferencialmente para TFs específicos), uma possibilidade que se apresenta cada vez mais factível, graças a redução gradativa no custo das tecnologias de medição de larga escala.

No que se refere a análise das CPTs, a conclusão obtida por este trabalho se mostra interessante. Os resultados obtidos para a análise do organismo que detinha mais medições de expressão e interação TF-DNA (Mycobacterium tuberculosis) foram piores que para o organismo que tinha menos (H. salinarum). Acredita-se que este resultado esteja ligado a dois fenômenos: a restrição técnica de limitar a quantidade de reguladores para um gene e ao fenômeno da ligação inativa. 
O primeiro pode ser contornado através da substituição do modelo de processamento adotado neste trabalho, migrando o limitado modelo baseado em clusters locais para a computação em nuvem, fenômeno já presenciado em outras áreas que fazem uso extensivo de Big Data, e que vem ganhando crescente adoção na Bioinformática.

Acredita-se que o fenômeno da ligação inativa, identificado para 63 dos 206 genes tenha contribuído para os resultados obtidos, já que este está intimamente associado ao tamanho da janela escolhida para estabelecer a interação, fornecendo evidências que apontam para a possibilidade de melhoramentos nos critérios adotados para esta escolha. A escolha de uma estratégia bem fundamentada será essencial em futuros estudos que façam uso de dados de interação TF-DNA para estabelecer a rede, uma vez que as melhorias nas tecnologias de sequenciamento os tornarão cada vez mais comuns.

A escolha de Redes Bayesianas como modelo foi considerada sensata, apesar das dificuldades computacionais e estatísticas encontradas, a análise para a $H$. salinarum resultou numa quantidade significativa de tabelas. Entretanto, estes resultados não foram validados biologicamente, isto é, não houve confirmação experimental da evidência computacional identificada pelas tabelas. Desta forma, novos trabalhos poderão utilizar este subconjunto como hipótese inicial para uma análise de sua influência na regulação do organismo.

Finalmente, espera-se que este trabalho contribua para futuras pesquisas envolvendo o organismo modelo $H$. salinarum, de tal forma que a integração de diferentes experimentos sirva para limitar o escopo de trabalhos que visem a compreensão de vias metabólicas específicas, permitindo, em última estância, a transferência dos conhecimentos obtidos em benefício da sociedade. 
Como uma das principais causas apresentadas para os resultados malsucedidos de CPTs calculadas sobre dados de tiling array foi a maldição da dimensionalidade, este apêndice tem como objetivo explorar esta hipótese. Uma forma simples de enfrentá-lo, de maneira geral, é adquirir mais medições para o fenômeno em questão, o que de modo algum é trivial no contexto biológico, tendo em vista as limitações éticas, biológicas e econômicas envolvidas.

Além das medições de tiling arraypreviamente utilizadas, a $H$. salinarum também conta com dados de microarray, que serão empregados numa tentativa de enfrentar a maldição da dimensionalidade na análise das CPTs. Porém, uma diferença importante, é que os dados de microarray tradicional não incluíam detectores para asRNAS. Desta forma, os nós deste tipo desaparecerão completamente nesta rede adaptada para microarray.

Os dados empregados referem-se as amostras obtidas em Bonneau et al. [1], contando com 1.495 medições de expressão gênica sob diferentes condições experimentais, como radiação ultra violeta, deleção de genes, etc. Uma descrição mais detalhada de cada um dos 413 experimentos, tal como a quantidade de medições temporais e a normalização empregada nos mesmos pode ser encontrada em [1]. Como a natureza experimental dos dados de microarray é igual a dos de tiling array, não há necessidade de alterar o cálculo das tabelas, ou seja, as etapas realizadas neste apêndice serão iguais às descritas anteriormente.

A primeira etapa refere-se a escolha da estrutura regulatória, ou seja, qual rede representará o fenômeno da regulação gênica, seguindo o preceito lógico da Navalha de Occam, usaremos a que foi proposta por este trabalho. A Figura A.1 usa o gene VNG0637G para exemplificar a simplificação da estrutura adotada nesta etapa, sem nós representando medições antisenso.

A rede resultante conta com 1.735 nós, uma quantidade substancialmente menor quando comparada a original. A redução está associada tanto a não existência de sondas, quanto a remoção de genes que foram anotadas apenas recentemente. Em particular para a figura apresentada, o nó tbpC não está presente (Figura 3.7) porque não existem medições associadas, como no tiling array - Figura 4.3.

Tendo escolhido a estrutura a ser utilizada, a próxima etapa consiste na estimativa das CPTs, seguindo os mesmos critérios adotados para os dados de tiling array. A Figura A.2 


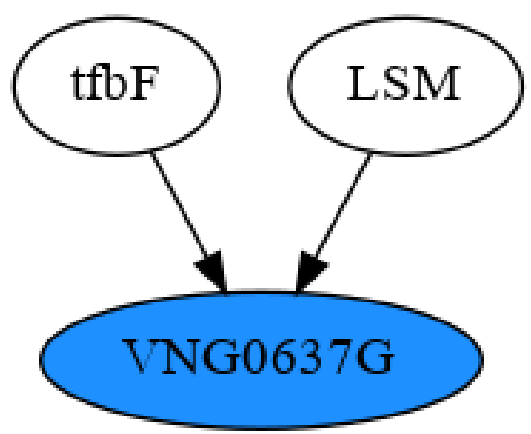

Figura A.1 - Exemplo de rede apresentando a simplificação adotada para a estrutura original.

apresenta de forma compilada os resultados obtidos para o microarray.

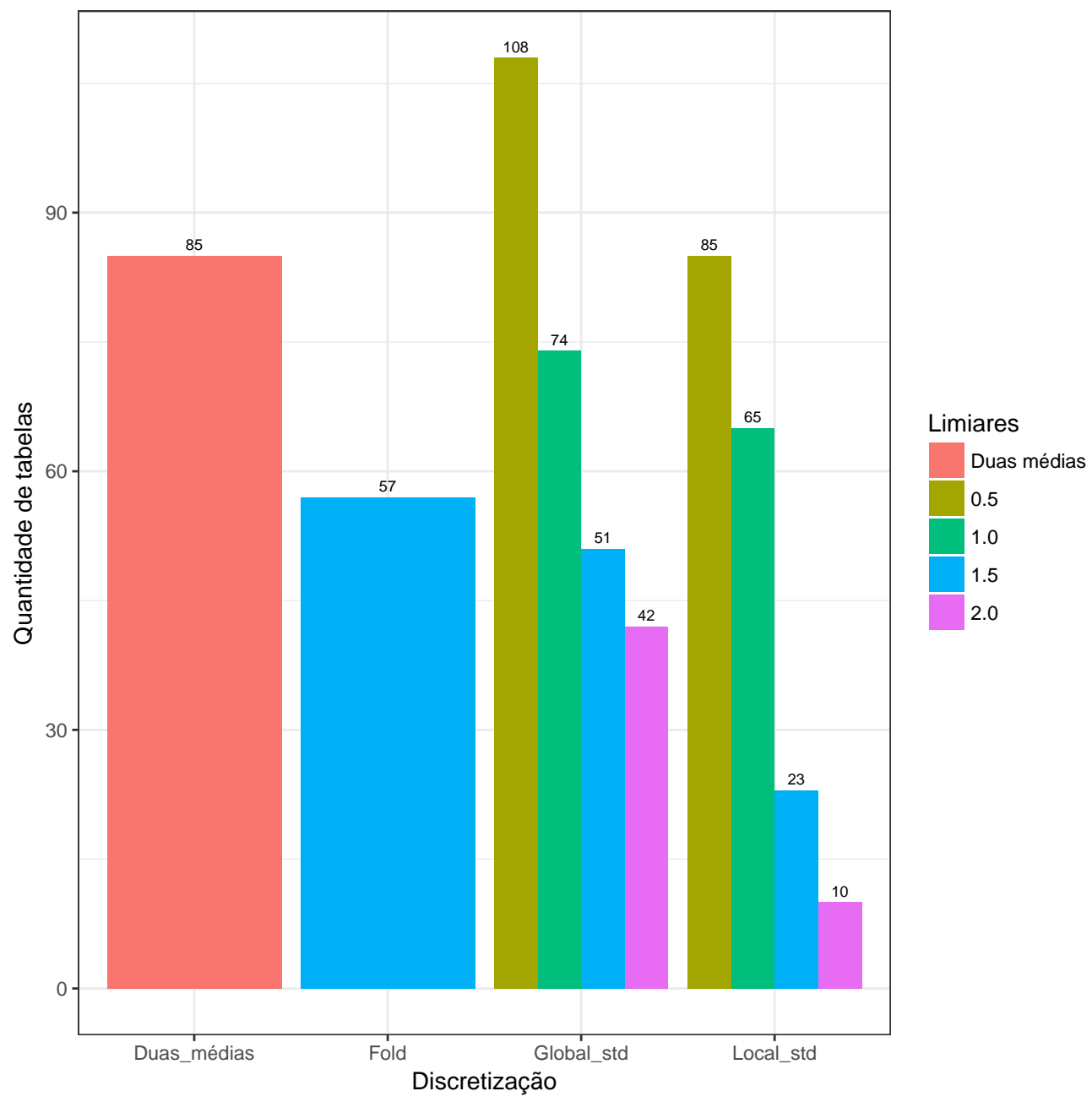

Figura A.2 - Genes classificados como controlados pelos reguladores propostos.

Os resultados compilados na Figura A.2 apresentam, mais uma vez, a pequena quantidade de genes detectados como de fato controlados por seus TFs. Apesar de detectar uma quantidade maior de genes, o que de forma alguma é uma surpresa, tendo em vista o número de medições de expressão em diferentes condições ambientais, é evidente que 
os resultados são desfavoráveis a hipótese inicial: identificar, globalmente, genes de fato controlados pelos reguladores propostos. 
A bactéria Mycobacterium tuberculosis é um grave patógeno humano, causador da maioria dos casos de tuberculose (TB) no mundo. Segundo a Organização Mundial da Saúde (OMS), em 2015 10,4 milhões de pessoas foram infectadas pela bactéria, causando a morte de 1,8 milhões e sendo uma das 10 principais causas de óbito no mundo [102]. A infecção por este patógeno se dá por meio da transmissão aérea, através de tosse, espirros ou cuspe de pessoas infectadas pela bactéria. Mediante o número de infecções e de casos fatais, modelar computacionalmente os processos intracelulares que ocorrem neste organismo, para melhorar ou descobrir formas de tratamento, se apresenta como uma opção fundamental para combatê-la.

A Mycobacterium tuberculosis é uma bactéria obrigatoriamente parasita, parte de um grupo de pelo menos outras 9 espécies. Seu crescimento é altamente dependente da presença de oxigênio, não produzindo esporos nem apresentando motilidade (séssil). Diferente de outras bactérias, o tempo de divisão de sua células é entre 15 e 20 horas, extremamente lento, se comparado com outros organismos que levam minutos. Outra característica importante é a sua incomum parede celular, rica em lipídeos, característica chave para sua virulência, impedindo, por exemplo, o tingimento através da técnica de Gram. Finalmente, seu genoma é de $\sim 4,4 \mathrm{Mpb}$, contando com 4.026 genes anotados.

Desde o sequenciamento do seu genoma, em 1998, inúmeros trabalhos buscaram descobrir formas mais eficientes de tratamento, entretanto, como este trabalho está fundamentado nos princípios da Biologia Sistêmica, iremos nos restringir apenas a estes casos. Neste contexto, um trabalho recente que busca modelar de forma sistêmica as interações intracelulares é o portal MTB, cujo objetivo é agregar diferentes abordagens de modelagem computacional, unindo medições de expressão gênica e interações proteína-DNA disponibilizadas por múltiplos grupos.

Uma das primeiras modelagens computacionais realizadas para este organismo foi a aplicação de GRNs, fato que não é surpresa, dado as considerações feitas anteriormente. Assim como a rede proposta para a H. salinarum, a deste organismo também se baseou em medições de interações físicas, obtidas por ChIP-seq [101]. Os dados fornecidos por este trabalho são referentes a 206 TFs (de um total de 214), coletados sob as condições experimentais específicas de superexpressão para cada gene, estabelecendo interações de 
forma muito similar a adotada para a $H$. salinarum: TFs detectados dentro de uma janela de $[-150,+70]$ pbs em relação aos TSS dos genes foram considerados como reguladores.

Além dos dados de imunoprecipitação, o organismo conta com medições de expressão gênica de tiling array. A existência deste conjunto de dados torna a análise probabilística da Mycobacterium tuberculosis uma tarefa mandatória para validar a análise proposta. Tal como para os dados de ChIP-seq, as condições das medições de expressão gênica existentes também são referentes aos 206 genes clonados, ou seja, existem medições de expressão mas mesmas condições em que as interações entre os TFs foram obtidas, uma vantagem significativa ao se comparar com a $H$. salinarum. Desta forma as medições de tiling array disponíveis referem-se aos 4.026 do organismo em 206 condições experimentais distintas [103].

Ao contrário de propor uma nova GRN (como feito para a $H$. salinarum), a estrutura proposta por Minch et al. [101] (disponível no portal) será adotada como verdadeira. Entretanto, para tornar possível a análise computacional desta estrutura, através de BNs, uma restrição foi imposta: limitar a quantidade de TFs que podem de fato controlar um gene. Esta imposição não foi necessária para a H. salinarum devido a escassez de dados, mas o cenário de abundância de TFs faz com que o caráter combinatorial do número de estados das tabelas de probabilidade seja contido, escolhendo uma quantidade de 9 TFs por gene, correspondendo ao máximo de $19.683\left(3^{9}\right)$ estados possíveis para cada uma das 4.026 tabelas. Finalmente, é importante destacar que apenas 143 TFs respeitaram o critério de janela adotado na criação da estrutura, e desta forma, a estrutura final não conta com todos os genes medidos inicialmente.

A análise das CPTs da Mycobacterium tuberculosis seguirá os mesmos passos adotados para a $H$. salinarum. Os dados da análise correspondem aos previamente descritos: [101] para a estrutura, e [103] para expressão gênica. Os resultados são apresentados de forma compilada na Figura B.1. 


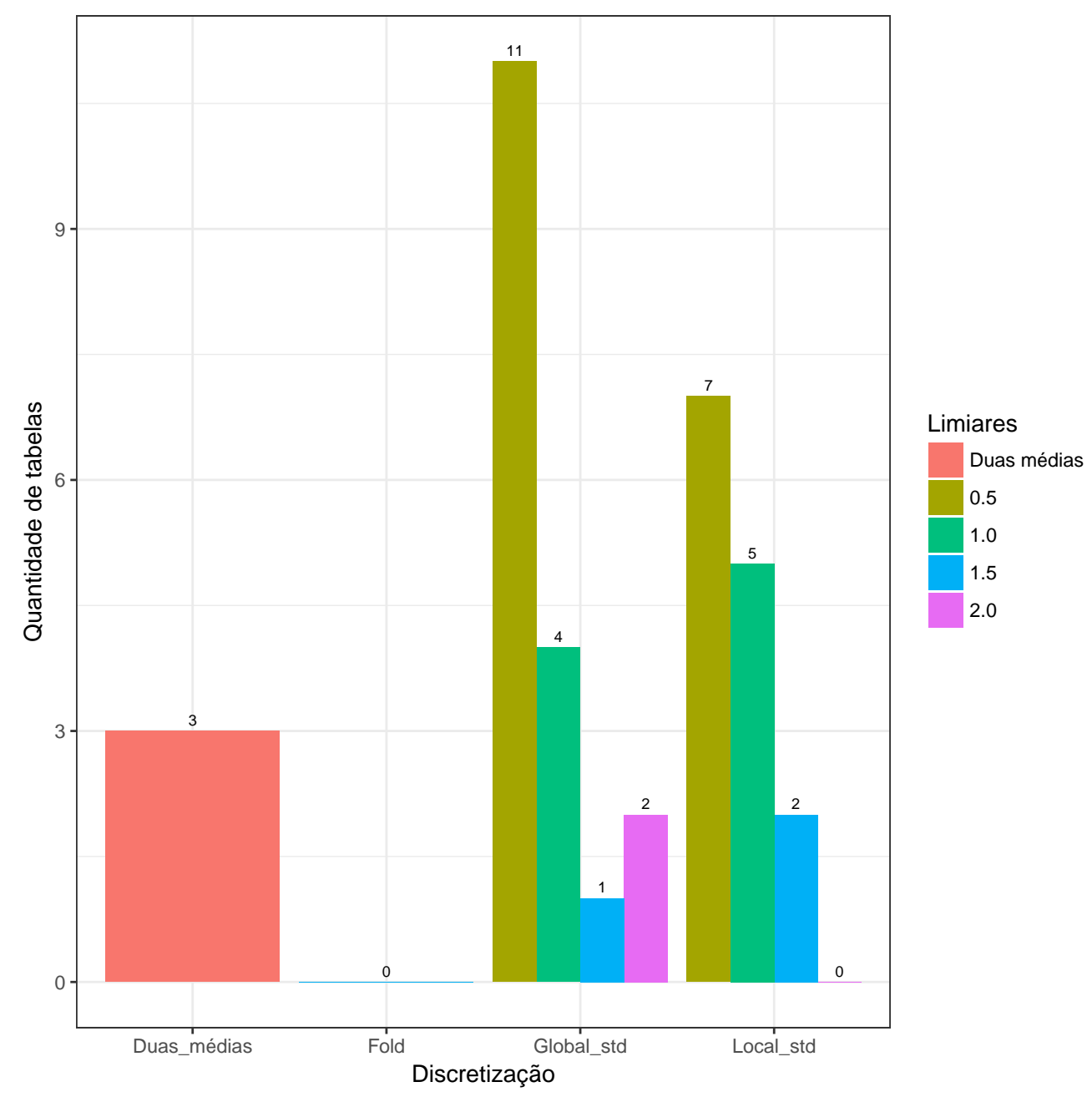

Figura B.1 - Genes classificados como controlados pelos reguladores propostos. Estes valores foram obtidos através da análise de entropia nas tabelas computadas nos dados de microarray discretizados.

Os resultados apresentados na Figura B.1 são similares aos obtidos nas duas análises anteriores, não permitindo, detectar de forma geral, genes controladores. Entretanto, uma diferença fundamental desta análise para as outras é a existência de medições para quase todos os TFs da MTB. Desta forma, o resultado esperado era detectar um conjunto significante de controladores, o que não ocorreu, desfavorecendo, mais uma vez, a análise proposta. 


\section{Referências}

1 BOnNEAU, R. et al. A Predictive Model for Transcriptional Control of Physiology in a Free Living Cell. Cell, v. 131, n. 7, p. 1354-1365, dec 2007. ISSN 0092-8674. 1, 27, 66

2 BROOKS, A. N. et al. A system-level model for the microbial regulatory genome. Molecular Systems Biology, v. 10, n. 7, p. n/a-n/a, 2014. ISSN 1744-4292. 1, 27, 42, 62

3 THARUN, S. Chapter 4 Roles of Eukaryotic Lsm Proteins in the Regulation of mRNA Function. International Review of Cell and Molecular Biology, v. 272, p. 149-189, 2008. ISSN 19376448. 2, 15

4 SAUER, E. Structure and RNA-binding properties of the bacterial LSm protein Hfa. RNA biology, Taylor Francis, v. 10, n. 4, p. 610-8, apr 2013. 2

5 ZARAMELA, L. S. Mapeamento de RNAs não-codificantes e suas interações com a chaperona Lsm na archaea Halobacterium salinarum Mapeamento de RNAs não-codificantes e suas interações com a chaperona Lsm na archaea Halobacterium salinarum. 2015. 2, 15, 36, 37

6 GEORG, J.; HESS, W. R. cis-antisense RNA, another level of gene regulation in bacteria. Microbiology and molecular biology reviews : MMBR, American Society for Microbiology, v. 75, n. 2, p. 286-300, jun 2011. ISSN 1098-5557. 2, 14, 34, 45

7 SZKLARCZYK, D. et al. STRING v10: Protein-protein interaction networks, integrated over the tree of life. Nucleic Acids Research, v. 43, n. D1, p. D447-D452, 2015. ISSN 13624962. 3, 26, 38

8 WOESE, C. R.; FOX, G. E. Phylogenetic structure of the prokaryotic domain: The primary kingdoms. Proceedings of the National Academy of Sciences of the United States of America, v. 74, n. 11, p. 5088-5090, 1977. 4, 5

9 WOESE, C. R.; KANDLER, O.; WHEELIS, M. L. Towards a natural system of organisms: proposal for the domains Archaea, Bacteria, and Eucarya. Proceedings of the National Academy of Sciences of the United States of America, National Academy of Sciences, v. 87, n. 12, p. 4576-9, jun 1990. ISSN 0027-8424. 4, 5

10 KOONIN, E. V. et al. Comparison of archaeal and bacterial genomes: computer analysis of protein sequences predicts novel functions and suggests a chimeric origin for the archaea. Molecular Microbiology, Blackwell Science Ltd, v. 25, n. 04, p. 619-637, aug 1997. ISSN 0950382X. 5

11 GUPTA, R. S. What are archaebacteria: life's third domain or monoderm prokaryotes related to Gram-positive bacteria? A new proposal for the classification of prokaryotic organisms. Molecular Microbiology, Blackwell Science Ltd, UK, v. 29, n. 3, p. 695-707, aug 1998. ISSN 0950-382X. 5 
12 GUPTA, R. S. The Natural Evolutionary Relationships among Prokaryotes. Critical Reviews in Microbiology, Taylor Francis, v. 26, n. 2, p. 111-131, jan 2000. ISSN 1040-841X. 5

13 YUTIN, N. et al. The deep archaeal roots of eukaryotes. Molecular biology and evolution, Oxford University Press, v. 25, n. 8, p. 1619-30, aug 2008. ISSN 1537-1719. 5

14 WILLIAMS, T. A. et al. An archaeal origin of eukaryotes supports only two primary domains of life. Nature, Nature Research, v. 504, n. 7479, p. 231-236, dec 2013. ISSN 0028-0836. 5

15 KNOLL, A. et al. Eukaryotic organisms in Proterozoic oceans. Philosophical Transactions of the Royal Society of London B: Biological Sciences, v. 361, n. 1470, 2006. 5

16 DASSARMA, S. et al. Post-genomics of the model haloarchaeon Halobacterium sp. NRC-1. Saline Systems, BioMed Central, v. 2, n. 1, p. 3, 2006. ISSN 17461448. 6

17 MESCHER, M. F.; STROMINGER, J. L. Structural (shape-maintaining) role of the cell surface glycoprotein of Halobacterium salinarium. Proceedings of the National Academy of Sciences of the United States of America, National Academy of Sciences, v. 73, n. 8, p. 2687-91, aug 1976. ISSN 0027-8424. 6

18 KAMEKURA, M.; KATES, M. No Title. Japan Society for Bioscience, Biotechnology, and Agrochemistry, v. 63, n. 6, 1999. ISSN 0916-8451. 6

19 NG, W. V. et al. Genome sequence of Halobacterium species NRC-1. Proceedings of the National Academy of Sciences, National Academy of Sciences, v. 97, n. 22, p. 12176-12181, oct 2000. ISSN 0027-8424, 1091-6490. 6

20 DASSARMA, S. et al. An improved genetic system for bioengineering buoyant gas vesicle nanoparticles from Haloarchaea. BMC biotechnology, BioMed Central, v. 13, p. 112, dec 2013. ISSN 1472-6750. 7

21 ORPHANIDES, G.; LAGRANGE, T.; REINBERG, D. The general transcription factors of RNA polymerase II. Genes development, v. 10, n. 21, p. 2657-83, nov 1996. ISSN 0890-9369. 10, 11

22 GRIFFITHS, A. J. F. An introduction to genetic analysis. [S.1.]: W.H. Freeman, 2000. 860 p. ISBN 0716735202. 11

23 GUPTA, R. S. Protein phylogenies and signature sequences: A reappraisal of evolutionary relationships among archaebacteria, eubacteria, and eukaryotes. Microbiology and molecular biology reviews : MMBR, American Society for Microbiology (ASM), v. 62, n. 4, p. 1435-91, dec 1998. ISSN 1092-2172. 13

24 GEHRING, A. M.; WALKER, J. E.; SANTANGELO, T. J. Transcription Regulation in Archaea. Journal of bacteriology, American Society for Microbiology, v. 198, n. 14, p. 1906-17, jul 2016. 13

25 FACCIOTTI, M. T. et al. General transcription factor specified global gene regulation in archaea. Proceedings of the National Academy of Sciences, National Acad Sciences, v. 104, n. 11, p. 4630-4635, mar 2007. ISSN 0027-8424. 13 
26 KARR, E. A. Transcription Regulation in the Third Domain. In: Advances in applied microbiology. [S.1.: s.n.], 2014. v. 89, p. 101-133. 13

27 LONDEI, P. Evolution of translational initiation: new insights from the archaea. FEMS Microbiology Reviews, v. 29, n. 2, 2005. 13

28 JUN, S.-H. et al. Archaeal RNA polymerase and transcription regulation. Critical reviews in biochemistry and molecular biology, NIH Public Access, v. 46, n. 1, p. 27-40, feb 2011. ISSN 1549-7798. 14

29 PELECHANO, V.; STEINMETZ, L. M. Gene regulation by antisense transcription. Nature Reviews Genetics, Nature Research, v. 14, n. 12, p. 880-893, nov 2013. ISSN 1471-0056. 14

30 Da Sacco, L.; BALDASSARRE, A.; MASOTTI, A. Bioinformatics tools and novel challenges in long non-coding RNAs (lncRNAs) functional analysis. International journal of molecular sciences, Multidisciplinary Digital Publishing Institute (MDPI), v. 13, n. 1, p. 97-114, 2012. ISSN 1422-0067. 14, 32

31 BABSKI, J. et al. Small regulatory RNAs in Archaea. RNA biology, v. 11, n. 5, p. 484-93, 2014. ISSN 1555-8584. 14, 45

32 FISCHER, S. et al. The archaeal Lsm protein binds to small RNAs. The Journal of biological chemistry, American Society for Biochemistry and Molecular Biology, v. 285, n. 45, p. 34429-38, nov 2010. ISSN 1083-351X. 15

33 BARABASI, A. L.; OLTVAI, Z. N. Network Biology: Understanding the Cell's Functional Organization. Nature Review, v. 5, n. February, p. 101-113, 2004. ISSN 1471-0056. 15

34 JONG, H. de. Modeling and Simulation of Genetic Regulatory Systems: A Literature Review. Journal of Computational Biology, v. 9, n. 1, p. 67-103, jan 2002. ISSN 1066-5277. 15,17

35 STUART, J. M. et al. A Gene-Coexpression Network for Global Discovery of Conserved Genetic Modules. Science, v. 302, n. 5643, 2003. 16

36 HECKER, M. et al. Gene regulatory network inference: data integration in dynamic models - a review. Biosystems, Elsevier, v. 96, n. 1, p. 86-103, 2009. 16, 17

37 SAKAMOTO, E.; IBA, H. Inferring a System of Differential Equations for a Gene Regulatory Network by using Genetic Programming. Citeseer. 17

38 SPIETH, C.; HASSIS, N.; STREICHERT, F. Comparing Mathematical Models on the Problem of Network Inference. 2006. 17

39 KAUFFMAN, S. Homeostasis and differentiation in random genetic control networks. Nature, v. 224, p. 177-178, 1969. 17

40 KAUFFMAN, S. et al. Random Boolean network models and the yeast transcriptional network. Proceedings of the National Academy of Sciences, National Acad Sciences, v. 100, n. 25 , p. $14796-14799,2003.17$ 
41 GARG, A. et al. Synchronous versus asynchronous modeling of gene regulatory networks. Bioinformatics (Oxford, England), Oxford University Press, v. 24, n. 17, p. 1917-25, sep 2008. ISSN 1367-4811. 18

42 LIANG, S.; FUHRMAN, S.; SOMOGYI, R. Reveal, a general reverse engineering algorithm for inference of genetic network architectures. 1998. 18, 26

43 LI, F. et al. The yeast cell-cycle network is robustly designed. Proceedings of the National Academy of Sciences of the United States of America, National Acad Sciences, v. 101, n. 14, p. 4781-4786, 2004. 18

44 DAVIDICH, M. I. et al. Boolean Network Model Predicts Cell Cycle Sequence of Fission Yeast. PLoS ONE, Public Library of Science, v. 3, n. 2, p. e1672, feb 2008. ISSN 1932-6203. 18

45 SHMULEVICH, I. et al. Probabilistic Boolean networks: a rule-based uncertainty model for gene regulatory networks. Bioinformatics, v. 18, n. 2, p. 261-274, 2002. 19

46 BARRERA, J. et al. Constructing Probabilistic Genetic Networks of Plasmodium falciparum from Dynamical Expression Signals of the Intraerythrocytic Development Cycle. In: Methods of Microarray Data Analysis V. Boston, MA: Springer US, 2007. p. 11-26. 19

47 DOUGHERTY, E. et al. Genomic signal processing and statistics. [S.l.]: Hindawi Pub. Corp., 2005. 19

48 KOBAYASHI, K.; HIRAISHI, K. Optimization-Based Approaches to Control of Probabilistic Boolean Networks. Algorithms 2017, Vol. 10, Page 31, Multidisciplinary Digital Publishing Institute, v. 10, n. 1, p. 31, 2017. 19

49 BARRERA, J. et al. Constructing probabilistic genetic networks of Plasmodium falciparum from dynamical expression signals of the intraerythrocytic development cycle, chapter 2. In: CITESEER. The Visual Computer. [S.1.], 2006. 20, 26

50 DARWICHE, A. Modeling and reasoning with Bayesian networks. [S.l.: s.n.], 2009. v. 1. 548 p. ISSN 18780326. ISBN 9780521884389. 20

51 PEARL, J. Probabilistic reasoning in intelligent systems: networks of plausible inference. [S.1.]: Morgan Kaufmann, 1988. 20, 21

52 KOLLER, D.; FRIEDMAN, N. Probabilistic graphical models: principles and techniques. [S.1.]: MIT press, 2009. 23, 24, 59

53 FRIEDMAN, N. et al. Using Bayesian networks to analyze expression data. Journal of computational biology, Mary Ann Liebert, Inc., v. 7, n. 3-4, p. 601-620, 2000. 23

54 BASSO, K. et al. Reverse engineering of regulatory networks in human B cells. Nature genetics, Nature Publishing Group, v. 37, n. 4, p. 382-390, 2005. 23

55 VIGNES, M. et al. Gene Regulatory Network Reconstruction Using Bayesian Networks, the Dantzig Selector, the Lasso and Their Meta-Analysis. PLoS ONE, Public Library of Science, v. 6, n. 12, p. e29165, dec 2011. ISSN 1932-6203. 23, 28 
56 MURPHY, K. P. Machine learning: a probabilistic perspective. [S.l.]: MIT press, 2012. 23,59

57 PERRIN, B.-E. et al. Gene networks inference using dynamic Bayesian networks. Bioinformatics, Oxford Univ Press, v. 19, n. suppl 2, p. ii138-ii148, 2003. 25

58 MURPHY, K.; MIAN, S. Modelling Gene Expression Data using Dynamic Bayesian Networks. 25

59 ZOU, M.; CONZEN, S. D. A new dynamic Bayesian network (DBN) approach for identifying gene regulatory networks from time course microarray data. Bioinformatics, Oxford Univ Press, v. 21, n. 1, p. 71-79, 2005. 25

60 KIM, S. Y.; IMOTO, S.; MIYANO, S. Inferring gene networks from time series microarray data using dynamic Bayesian networks. Briefings in bioinformatics, Oxford Univ Press, v. 4, n. 3, p. 228-235, 2003. 25

61 CHEN, H. et al. Integrating epigenetic prior in dynamic Bayesian network for gene regulatory network inference. 2013 IEEE Symposium on Computational Intelligence in Bioinformatics and Computational Biology (CIBCB), p. 76-82, 2013. 25

62 LÄHDESMÄKI, H. et al. Relationships between probabilistic Boolean networks and dynamic Bayesian networks as models of gene regulatory networks. Signal Processing, Elsevier, v. 86, n. 4, p. 814-834, 2006. 25

63 JEONG, H. et al. Lethality and centrality in protein networks. Nature, v. 411, n. 6833, p. 41-42, 2001. ISSN 0028-0836. 26

64 AKUTSU, T. et al. Identification of genetic networks from a small number of gene expression patterns under the Boolean network model. Pacific symposium on biocomputing, v. 4, p. 17-28, 1999. 26

65 HECKERMAN, D.; GEIGER, D.; CHICKERING, D. M. Learning Bayesian networks: The combination of knowledge and statistical data. Machine learning, Springer, v. 20, n. 3, p. 197-243, 1995. 26

66 HARTEMINK, A. J. et al. Using graphical models and genomic expression data to statistically validate models of genetic regulatory networks. Pacific Symposium on Biocomputing. Pacific Symposium on Biocomputing, p. 422-33, 2001. ISSN 2335-6936. 27

67 GILMOUR, D. S.; LIS, J. T. Detecting protein-DNA interactions in vivo: distribution of RNA polymerase on specific bacterial genes. Proceedings of the National Academy of Sciences of the United States of America, National Academy of Sciences, v. 81, n. 14, p. 4275-9, jul 1984. 29

68 NEILL, L. P. O. Õ.; TURNER, B. M. Immunoprecipitation of native chromatin : NChIP. v. 31, p. 76-82, 2003. 30

69 CAREY, M. F.; PETERSON, C. L.; SMALE, S. T. Chromatin immunoprecipitation (ChIP). Cold Spring Harbor Protocols, Cold Spring Harbor Laboratory Press, v. 2009, n. 9, p. pdb--prot5279, 2009. 30 
70 SCHONES, D. E.; ZHAO, K. Genome-wide approaches to studying chromatin modifications. Nature Reviews Genetics, Nature Publishing Group, v. 9, n. 3, p. 179-191, 2008. 31

71 HO, J. W. K. et al. ChIP-chip versus ChIP-seq: lessons for experimental design and data analysis. BMC genomics, BioMed Central, v. 12, n. 1, p. 1, 2011. 30

72 KEENE, J. D.; KOMISAROW, J. M.; FRIEDERSDORF, M. B. RIP-Chip: the isolation and identification of mRNAs, microRNAs and protein components of ribonucleoprotein complexes from cell extracts. v. 3021, n. 1, 2006. 31

73 WURTH, L. et al. Versatility of RNA-Binding Proteins in Cancer. Comparative and Functional Genomics, Hindawi Publishing Corporation, v. 2012, p. 1-11, 2012. ISSN 1531-6912. 32

74 WADE, J. T.; GRAINGER, D. C. Pervasive transcription: illuminating the dark matter of bacterial transcriptomes. Nature Reviews Microbiology, v. 12, n. 9, p. 647-653, jul 2014. ISSN 1740-1526. 33

75 CLARK, M. B. et al. The Reality of Pervasive Transcription. PLoS Biology, Public Library of Science, v. 9, n. 7, p. e1000625, jul 2011. 33

76 BAKEL, H. van et al. Most "Dark Matter" Transcripts Are Associated With Known Genes. PLoS Biology, Public Library of Science, v. 8, n. 5, p. e1000371, may 2010. ISSN 1545-7885. 33

77 LLORÉNS-RICO, V. et al. Bacterial antisense RNAs are mainly the product of transcriptional noise. Science advances, American Association for the Advancement of Science, v. 2, n. 3, p. e1501363, mar 2016. 33

78 SHARMA, C. M. et al. The primary transcriptome of the major human pathogen Helicobacter pylori. Nature, Nature Publishing Group, v. 464, n. 7286, p. 250-255, mar 2010. 33

79 BARE, J. C. et al. Integration and visualization of systems biology data in context of the genome. BMC Bioinformatics, BioMed Central, v. 11, n. 1, p. 382, 2010. 34

80 KOIDE, T. et al. Prevalence of transcription promoters within archaeal operons and coding sequences. Molecular systems biology, European Molecular Biology Organization, v. 5 , p. $285,2009.36,54,55$

81 SHARMA, K. et al. The RosR transcription factor is required for gene expression dynamics in response to extreme oxidative stress in a hypersaline-adapted archaeon. $B M C$ Genomics, BioMed Central, v. 13, n. 1, p. 351, 2012. 36

82 SCHMID, A. K. et al. Two transcription factors are necessary for iron homeostasis in a salt-dwelling archaeon. Nucleic Acids Research, Oxford University Press, v. 39, n. 7, p. 2519-2533, apr 2011. ISSN 03051048. 36

83 PLAISIER, C. C. L. et al. Evolution of context dependent regulation by expansion of feast/famine regulatory proteins. BMC Systems Biology, BioMed Central, v. 8, n. 1, p. 122 , dec 2014. ISSN 1752-0509. 36, 54, 55 
84 SEITZER, P. et al. A Monte Carlo-based framework enhances the discovery and interpretation of regulatory sequence motifs. BMC bioinformatics, BioMed Central, v. 13, p. $317,2012.36$

85 CATEN, F. T. E. N. A transcrição pervasiva na archaea. 2016. 37, 38, 40

86 REISS, D. J.; FACCIOTTI, M. T.; BALIGA, N. S. Model-based deconvolution of genome-wide DNA binding. Bioinformatics (Oxford, England), Oxford University Press, v. 24 , n. 3 , p. 396-403, feb 2008. ISSN 1367-4811. 38, 39, 42

87 AMMAN, F. et al. TSSAR: TSS annotation regime for dRNA-seq data. BMC Bioinformatics, BioMed Central, v. 15, n. 1, p. 89, 2014. 39, 40

88 LAMBERT, D. Zero-Inflated Poisson Regression, with an Application to Defects in Manufacturing. Technometrics, v. 34, n. 1, p. 1, feb 1992. 40

89 ZARAMELA, L. S. et al. Transcription Start Site Associated RNAs (TSSaRNAs) Are Ubiquitous in All Domains of Life. PLoS ONE, Public Library of Science, v. 9, n. 9, p. e107680, sep 2014. ISSN 1932-6203. 41

90 COSTA, L. d. F. F.; RODRIGUES, F. A.; CRISTINO, A. S. Complex networks: The key to systems biology. Disponível em: <http://www.scielo.br/pdf/gmb/v31n3/a01v31n3. $\mathrm{pdf}>.47$

91 PAVLOPOULOS, G. A. et al. Using graph theory to analyze biological networks. BioData mining, BioMed Central, v. 4, p. 10, apr 2011. 47

92 COSTA, L. d. F. et al. Characterization of complex networks: A survey of measurements. may 2005. 47, 49

93 MALONE, J. H.; OLIVER, B. Microarrays, deep sequencing and the true measure of the transcriptome. BMC biology, BioMed Central, v. 9, n. 1, p. 1, 2011. 53

94 BEER, K. D. et al. Model organisms retain an "ecological memory"of complex ecologically relevant environmental variation. Applied and environmental microbiology, American Society for Microbiology (ASM), v. 80, n. 6, p. 1821-31, mar 2014. ISSN 1098-5336. 54, 55

95 WURTMANN, E. J. et al. An evolutionarily conserved RNase-based mechanism for repression of transcriptional positive autoregulation. Molecular Microbiology, v. 92, n. 2, p. 369-382, apr 2014. ISSN 0950382X. 54, 55

96 TURKARSLAN, S. et al. Niche adaptation by expansion and reprogramming of general transcription factors. Molecular systems biology, European Molecular Biology Organization, v. 7, p. 554, nov 2011. ISSN 1744-4292. 54, 55

97 HICKS, S. C.; IRIZARRY, R. A. When to use Quantile Normalization? bioRxiv, p. 012203, 2014. 55

98 MARTINS-JR, D. C. Seleção de características e predição intrinsecamente multivariada em identificação de redes de regulação gênica. p. 178, 2009. 56, 57

99 SCHMID, A. K. et al. The anatomy of microbial cell state transitions in response to oxygen. Genome research, Cold Spring Harbor Laboratory Press, v. 17, n. 10, p. 1399-413, oct 2007. 58 
100 PGMPY. Python library for creation, manipulation and implementation of Probablistic Graphical Models (PGM). 2013. Disponível em: <http://pgmpy.org/>. 60

101 MINCH, K. J. et al. The DNA-binding network of Mycobacterium tuberculosis. Nature Communications, Nature Publishing Group, v. 6, p. 5829, jan 2015. 62, 69, 70

102 WHO. World Health Organization / Tuberculosis. 2016. Disponível em: <http://www.who.int/mediacentre/factsheets/fs104/en/>. 69

103 RUSTAD, T. R. et al. Mapping and manipulating the Mycobacterium tuberculosis transcriptome using a transcription factor overexpression-derived regulatory network. p. $1-11,2014.70$ 